\title{
NEVADA NATIONAL SECURITY SITE \\ 2012 WASTE MANAGEMENT MONITORING REPORT \\ AREA 3 AND AREA 5 RADIOACTIVE WASTE \\ MANAGEMENT SITES
}

August 2013

Prepared for:

U.S. Department of Energy

National Nuclear Security Administration Nevada Field Office

Prepared by:

National Security Technologies, LLC Las Vegas, Nevada 


\section{DISCLAIMER}

Reference herein to any specific commercial product, process, or service by trade name, trademark, manufacturer, or otherwise does not necessarily constitute or imply its endorsement, recommendation, or favoring by the United States Government or any agency thereof.

Available for sale to the public, in paper, from:

U.S. Department of Commerce

National Technical Information Service

5301 Shawnee Road

Alexandria, VA 22312

Phone: 800.553.6847

Fax: 703.605.6900

E-mail: orders@ntis.gov

Online Ordering: http://www.ntis.gov/help/ordermethods.aspx

Available electronically at http://www.osti.gov/bridge

Available for a processing fee to the U.S. Department of Energy and its contractors, in paper, from:

U.S. Department of Energy

Office of Scientific and Technical Information

P.O. Box 62

Oak Ridge, TN 37831-0062

Phone: 865.576.8401

Fax: 865.576.5728 


\section{NEVADA NATIONAL SECURITY SITE \\ 2012 WASTE MANAGEMENT MONITORING REPORT AREA 3 AND AREA 5 RADIOACTIVE WASTE MANAGEMENT SITES}

August 2013

Prepared for:

U.S. Department of Energy

National Nuclear Security Administration Nevada Field Office

\section{Prepared by:}

National Security Technologies, LLC Las Vegas, Nevada 
THIS PAGE INTENTIONALLY LEFT BLANK 


\section{EXECUTIVE SUMMARY}

Environmental monitoring data are collected at and around the Area 3 and Area 5 Radioactive Waste Management Sites (RWMSs) at the Nevada National Security Site (NNSS). These data are associated with radiation exposure, air, groundwater, meteorology, and vadose zone. This report summarizes the 2012 environmental data to provide an overall evaluation of RWMS performance and to support environmental compliance and performance assessment (PA) activities. Some of these data (e.g., radiation exposure, air, and groundwater) are presented in other reports (National Security Technologies, LLC, 2012; 2013a; 2013b).

Direct radiation monitoring data indicate exposure levels at the RWMSs are within the range of background levels measured at the NNSS. Slightly elevated exposure levels outside the Area 3 RWMS are attributed to nearby historical aboveground nuclear weapons tests. Air monitoring data show tritium concentrations in water vapor and americium and plutonium concentrations in air particles are only slightly above detection limits and background levels. The measured levels of radionuclides in air particulates and moisture are below Derived Concentration Standards for these radionuclides. Groundwater monitoring data indicate the groundwater in the uppermost aquifer beneath the Area 5 RWMS is not impacted by RWMS operations. Results of groundwater analysis from wells around the Area 5 RWMS were all below established investigation levels. Leachate samples collected from the leachate collection system at the mixed low-level waste cell were below established contaminant regulatory limits.

The 133.9 millimeters $(\mathrm{mm})$ (5.27 inches [in.]) of precipitation at the Area 3 RWMS during 2012 is $12 \%$ below the average of $153.0 \mathrm{~mm}$ (6.02 in.), and the $137.6 \mathrm{~mm}$ (5.42 in.) of precipitation at the Area 5 RWMS during 2012 is $11 \%$ below the average of $122.4 \mathrm{~mm}$ (4.82 in.). Water balance measurements indicate that evapotranspiration from the vegetated weighing lysimeter dries the soil and prevents downward percolation of precipitation more effectively than evaporation from the bare-soil weighing lysimeter. Automated vadose zone monitoring on Area 5 and Area 3 RWMS cell covers show no evidence of precipitation percolating through the cover to the waste. Moisture from precipitation did not percolate below 60 centimeters $(\mathrm{cm})(2$ feet $[\mathrm{ft}])$ in the vegetated final cover on the U-3ax/bl disposal unit at the Area 3 RWMS, and moisture from precipitation and irrigation did not percolate below $45 \mathrm{~cm}(1.5 \mathrm{ft})$ on the 92-Acre Area final cover. Irrigation was applied to this cover for seed germination and plant growth. During 2012, there was no drainage through 2.4 meters $(8 \mathrm{ft}$ ) of soil from the Area 3 drainage lysimeters that received only natural precipitation. Twenty percent of the applied precipitation and irrigation drained from the bare-soil drainage lysimeter that received 3 times natural precipitation.

All 2012 monitoring data indicate that the Area 3 and Area 5 RWMSs are performing within expectations of the model and parameter assumptions for the facility PAs. 
THIS PAGE INTENTIONALLY LEFT BLANK 


\section{TABLE OF CONTENTS}

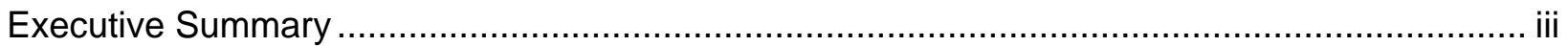

List of Acronyms and Abbreviations...................................................................... vii

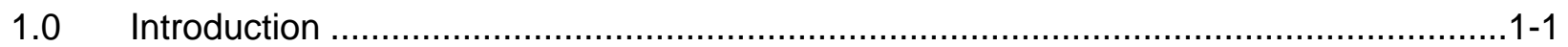

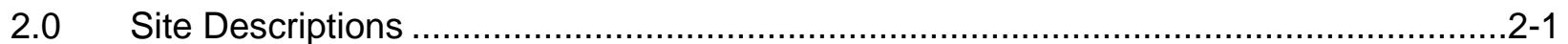

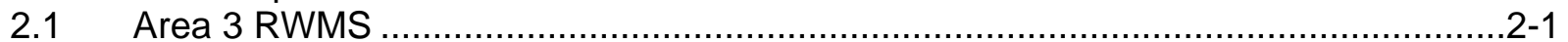

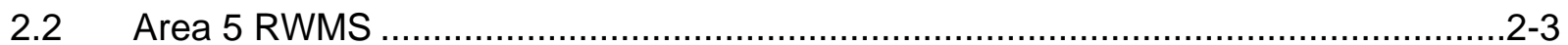

2.3 Hydrologic Conceptual Model of the Area 3 and Area 5 RWMS ............................2-3

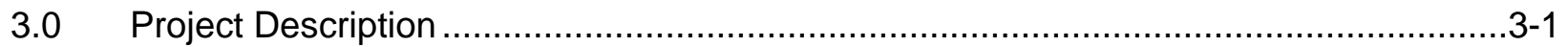

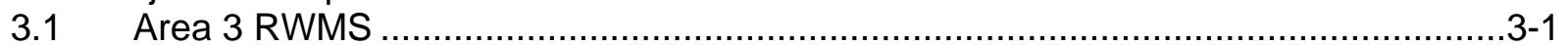

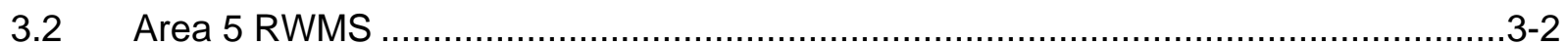

4.0 Environmental Monitoring Data .........................................................................

4.1 Types of Environmental Monitoring Data .......................................................

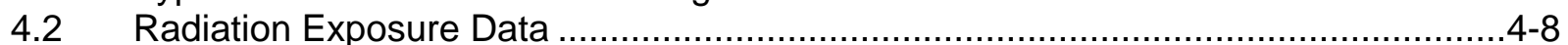

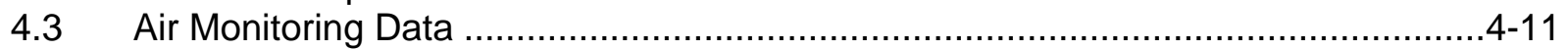

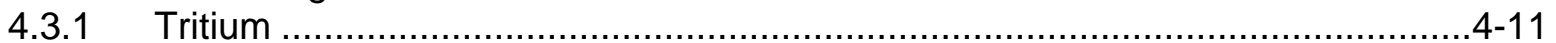

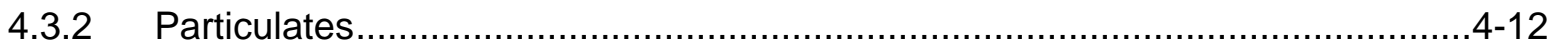

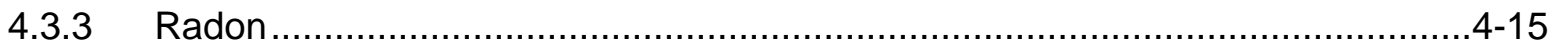

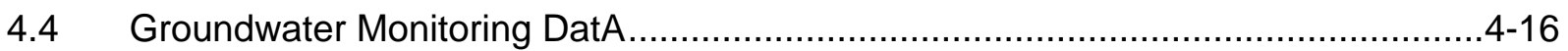

4.4.1 Groundwater Monitoring at the Pilot Wells ............................................

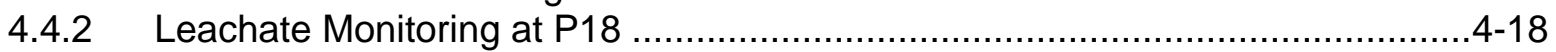

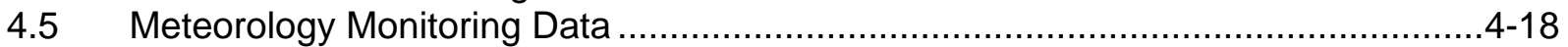

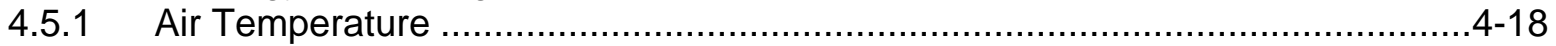

4.5.2 Relative Humidity ...............................................................................

4.5.3 Barometric Pressure ................................................................................ $4-20$

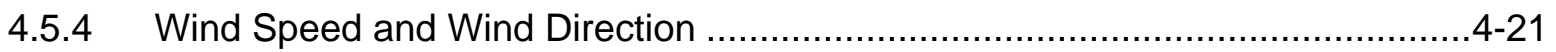

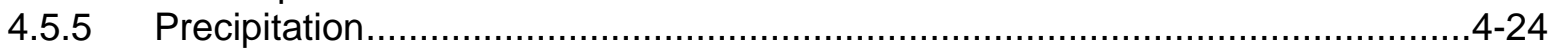

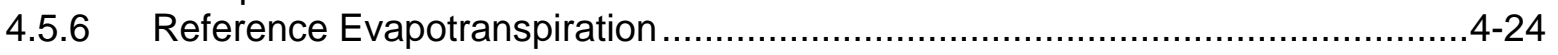

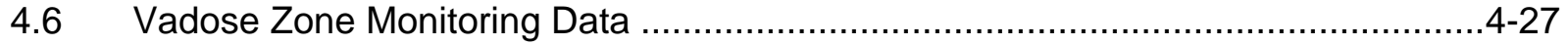

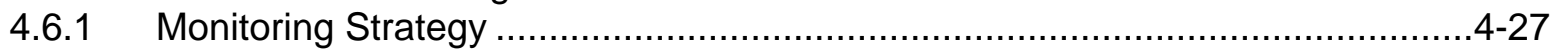

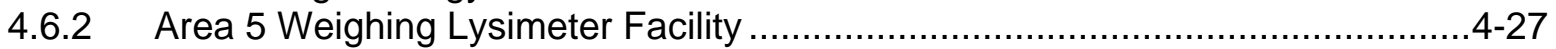

4.6.3 Automated Waste Cover Monitoring System ............................................4-31

4.6.4 Area 3 Drainage Lysimeter Facility .......................................................... 44

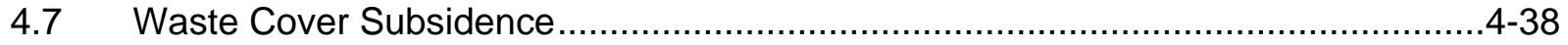

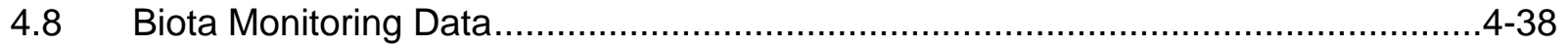

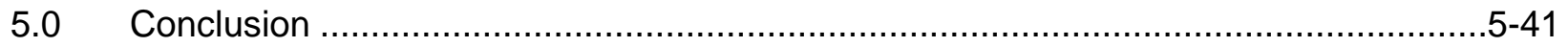

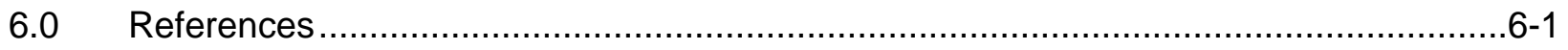

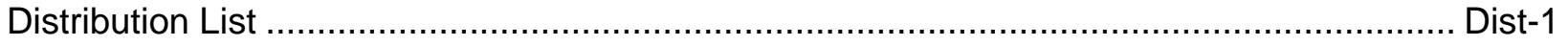




\section{LIST OF FIGURES}

Figure 2-1 Location of the Area 3 and Area 5 RWMSs..................................................2

Figure 2-2 Vadose Zone Conceptual Models of the Area 3 and Area 5 RWMSs ...................2-4

Figure 3-1 Monitoring Locations at the Area 3 RWMS ................................................

Figure 3-2 Monitoring Locations at the Area 5 RWMS ................................................

Figure 4-1 Annual Radiation Exposure Rates at the Area 3 RWMS ..................................4-9

Figure 4-2 Quarterly Average Daily Exposure Rates at the Area 3 RWMS and NNSS

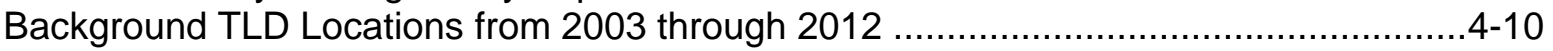

Figure 4-3 Quarterly Average Daily Exposure Rates at the Area 5 RWMS and NNSS

Background TLD Locations from 2003 through 2012 ............................................4-10

Figure 4-4 Tritium Concentration in Air at the Area 3 and Area 5 RWMSs during 2012........4-12

Figure 4-5 Concentration of ${ }^{241} \mathrm{Am}$ in Air at the Area 3 and Area 5 RWMSs during 2012......4-13

Figure 4-6 Concentration of ${ }^{238} \mathrm{Pu}$ in Air at the Area 3 and Area 5 RWMS during $2012 \ldots \ldots . .4-14$

Figure 4-7 Concentration of ${ }^{239+240} \mathrm{Pu}$ in Air at the Area 3 and Area 5 RWMSs during 2012 ..4-14

Figure 4-8 Radon Flux Measurement Locations in Area 5 RWMS .................................4-15

Figure 4-9 Radon Flux Results from 2002 through 2012 .......................................... 4-16

Figure 4-10 Groundwater Elevation at the Area 5 RWMS Pilot Wells ..............................4-17

Figure 4-11 Daily Maximum and Minimum $3 \mathrm{~m}$ Temperature at Area 3 and Area 5 RWMS ..4-19

Figure 4-12 Daily Average Relative Humidity at the Area 3 and Area 5 RWMSs .................4-20

Figure 4-13 Average Barometric Pressure at the Area 3 and Area 5 RWMSs ....................4-21

Figure 4-14 Daily $3 \mathrm{~m}$ Wind Speed at the Area 3 RWMS .................................................4-22

Figure 4-15 Daily $3 \mathrm{~m}$ Wind Speed at the Area 5 RWMS ............................................4-22

Figure 4-16 Wind Rose Diagram for the Area 3 RWMS .............................................4-23

Figure 4-17 Wind Rose Diagram for the Area 5 RWMS ............................................. $4-23$

Figure 4-18 Daily Precipitation at the Area 3 RWMS ................................................... $4-25$

Figure 4-19 Daily Precipitation at the Area 5 RWMS ..................................................4-25

Figure 4-20 Historical Precipitation Record for the Buster-Jangle $Y$ and the Area 3 RWMS..4-26

Figure 4-21 Historical Precipitation Record for the Well 5B and Area 5 RWMS ..................4-26

Figure 4-22 Weighing Lysimeter Data from March 1994 to December 2012 ......................4-28

Figure 4-23 Precipitation, ET, E, and Storage for the Weighing Lysimeters during 2012......4-30

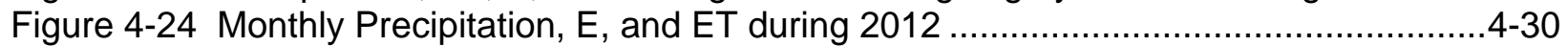

Figure 4-25 Soil Water Content in the Pit 5 Floor ....................................................4-31

Figure 4-26 Water Content in the 92 Acre Area Cover at Pit 5S ..................................4-32

Figure 4-27 Temperatures above an RTG at Pit 5 ................................................... 4 -33

Figure 4-28 Soil Water Content in the U-3ax/bl Cover .................................................4-34

Figure 4-29 Cumulative Drainage from the Drainage Lysimeters .....................................4-36

Figure 4-30 Soil Water Storage in the Drainage Lysimeters ....................................... $4-37$

Figure 4-31 Percent Plant Cover on the U-3ax/bl Cover ..............................................4-39

\section{LIST OF TABLES}

Table 4-1 Environmental Monitoring at the Area 3 RWMS ................................................4-6

Table 4-2 Environmental Monitoring at the Area 5 RWMS ..........................................

Table 4-3 Investigation Levels and Results from 2012 Groundwater Monitoring...................4-17

Table 4-4 Weighing Lysimeters Percent Cover ..........................................................4-28

Table 4-5 Area 3 Drainage Lysimeter Treatments in 2012 .........................................4-36

Table 4-6 Area 3 Drainage Lysimeter Percent Cover ..................................................4-37 


\section{LIST OF ACRONYMS AND ABBREVIATIONS}

\begin{tabular}{|c|c|}
\hline AGL & above ground level \\
\hline Am & americium \\
\hline AMSL & above mean sea level \\
\hline ARL/SORD & Air Resources Laboratory, Special Operations and Research Division \\
\hline BJY & Buster-Jangle $Y$ \\
\hline $\mathrm{BN}$ & Bechtel Nevada \\
\hline${ }^{\circ} \mathrm{C}$ & degrees Celsius \\
\hline CAU & Corrective Action Unit \\
\hline CFR & Code of Federal Regulations \\
\hline $\mathrm{cm}$ & centimeter(s) \\
\hline Cs & cesium \\
\hline DCS & Derived Concentration Standard \\
\hline DOE & U.S. Department of Energy \\
\hline$E$ & evaporation \\
\hline EPA & U.S. Environmental Protection Agency \\
\hline ET & evapotranspiration \\
\hline $\mathrm{ET}_{\text {ref }}$ & reference evapotranspiration \\
\hline${ }^{\circ} \mathrm{F}$ & degrees Fahrenheit \\
\hline $\mathrm{ft}$ & foot; feet \\
\hline $\mathrm{ft}^{3}$ & cubic feet \\
\hline GCD & greater confinement disposal \\
\hline IL & investigation level \\
\hline in. & inch(es) \\
\hline $\mathrm{km}$ & kilometer(s) \\
\hline $\mathrm{kPa}$ & kilopascal(s) \\
\hline $\mathrm{L}$ & liter(s) \\
\hline LLW & low-level waste \\
\hline$\mu g / L$ & microgram(s) per liter \\
\hline $\mathrm{m}$ & meter(s) \\
\hline $\mathrm{m}^{3}$ & cubic meter(s) \\
\hline $\mathrm{m} / \mathrm{s}$ & meter(s) per second \\
\hline MCL & maximum contaminant level \\
\hline MEDA & Meteorological Data Acquisition \\
\hline $\mathrm{mg} / \mathrm{L}$ & milligram(s) per liter \\
\hline $\mathrm{mi}$ & mile(s) \\
\hline MLLW & mixed low-level waste \\
\hline $\mathrm{mm}$ & millimeter(s) \\
\hline $\mathrm{mmhos} / \mathrm{cm}$ & millimho(s) per centimeter \\
\hline
\end{tabular}




$\begin{array}{ll}\text { mph } & \text { mile(s) per hour } \\ \text { mR } & \text { milliroentgen(s) } \\ \text { mR/day } & \text { milliroentgen(s) per day } \\ \text { mR/yr } & \text { milliroentgen(s) per year } \\ \text { mrem } & \text { millirem(s) } \\ \text { mrem/yr } & \text { millirem(s) per year } \\ & \\ \text { NNSA/NSO } & \text { U.S. Department of Energy, National Nuclear Security Administration Nevada } \\ \text { NNSS } & \text { Site Office } \\ \text { NSTec } & \text { Nevada National Security Site } \\ \text { PA } & \text { performal Security Technologies, LLC } \\ \text { PCB } & \text { polychlorinated biphenyls } \\ \text { pCi/L } & \text { picocurie(s) per liter } \\ \text { pCi/m } & \text { picocurie(s) per cubic meter } \\ \text { pCi/m }{ }^{2} / s & \text { picocurie(s) per square meter per second } \\ \text { PSI } & \text { pound(s) per square inch } \\ \text { PST } & \text { Pacific Standard Time } \\ \text { Pu } & \text { plutonium } \\ \text { RCRA } & \text { Resource Conservation and Recovery Act } \\ \text { RREMP } & \text { Routine Radiological Environmental Monitoring Plan } \\ \text { RTD } & \text { resistance temperature detector(s) } \\ \text { RTG } & \text { radioisotope thermoelectric generator(s) } \\ \text { RWMS } & \text { Radioactive Waste Management Site } \\ \text { SC } & \text { specific conductance } \\ \text { Sr } & \text { strontium } \\ \text { TCLP } & \text { Toxicity Characteristic Leaching Procedure } \\ \text { TDR } & \text { time-domain reflectometry } \\ \text { TLD } & \text { thermoluminescent dosimeter } \\ \text { TOC } & \text { total organic carbon } \\ \text { TOX } & \text { total organic halides } \\ \text { VWC } & \text { volumetric water content } \\ & \end{array}$




\subsection{INTRODUCTION}

This document summarizes the calendar year 2012 waste management environmental monitoring data for the Area 3 and Area 5 Radioactive Waste Management Sites (RWMSs). Characterization reports for the Area 3 RWMS (National Security Technologies, LLC [NSTec], 2007a) and the Area 5 RWMS (Bechtel Nevada [BN], 2006) provide descriptions of each RWMS including location, setting, waste disposal operations, and monitoring programs. These reports also provide brief summaries of characterization and monitoring data. The Closure Plan for the Area 3 Radioactive Waste Management Site at the Nevada Test Site (NSTec, 2007b) and the Closure Plan for the Area 5 Radioactive Waste Management Site at the Nevada Test Site (NSTec, 2008) identify the regulatory requirements and describe the intended approach for closing and monitoring the RWMSs after waste disposal is finished.

This report summarizes environmental data, as briefly defined below:

- Direct radiation monitoring conducted to confirm that RWMS activities do not result in significant exposure above background levels

- Air monitoring conducted to confirm that RWMS activities do not result in significant radionuclide concentrations above background levels and confirm compliance with National Emission Standards for Hazardous Air Pollutants

- Groundwater monitoring conducted, as required by U.S. Environmental Protection Agency (EPA) regulations and U.S. Department of Energy (DOE) orders, to assess the water quality of the aquifer beneath the Area 5 RWMS and to confirm that Area 5 RWMS activities are not affecting the aquifer

- Vadose zone monitoring conducted to assess the water balance at the RWMSs, confirm the assumptions made in performance assessments (PAs) (including no downward pathway), and evaluate the performance of monolayer-evapotranspirative waste covers

- Subsidence monitoring conducted to assess the stability of waste cover

- Biota monitoring to assess the engineered, planted, vegetated, final cover on closed waste cells and evaluate the upward biological pathway for radionuclides

These data are collected by NSTec, as required by various DOE orders and requirements from the Code of Federal Regulations (CFR). For a detailed description of these regulatory drivers, refer to the closure plans for the Area 3 RWMS and the Area 5 RWMS (NSTec, 2007b; 2008). These regulatory drivers exist to mitigate risk to the public and environment and include the following:

- DOE O 435.1, "Radioactive Waste Management"

- DOE O 436.1, "Departmental Sustainability"

- DOE O 458.1, "Radiation Protection of the Public and the Environment"

- 40 CFR 61, "National Emission Standards for Hazardous Air Pollutants"

- 40 CFR 264, "Standards for Owners and Operators of Hazardous Waste Treatment, Storage, and Disposal Facilities"

- 40 CFR 265, "Interim Status Standards for Owners and Operators of Hazardous Waste Treatment, Storage, and Disposal Facilities" 
Environmental monitoring data are collected and analyzed as described in Quality Assurance, Analysis, and Sampling Plans, which can be found in the Nevada Test Site Routine Radiological Environmental Monitoring Plan (RREMP) (BN, 2003). The RREMP was written with a Data Quality Objectives-driven process to identify what and how technically defensible environmental monitoring data are collected. 


\subsection{SITE DESCRIPTIONS}

\subsection{AREA 3 RWMS}

The Area 3 RWMS is located on Yucca Flat within the Nevada National Security Site (NNSS). Yucca Flat is an elongated, sediment-filled basin that trends roughly north-south; the northsouth long axis extends approximately 27 kilometers (km) (17 miles [mi]), and the short axis extends approximately 16 km (10 mi). Yucca Flat is bound by Quartzite Ridge and Rainier Mesa on the north, the Halfpint Range on the east, the Massachusetts Mountains and CP Hills on the south, and Mine Mountain and the Eleana Range on the west (Figure 2-1). The Yucca Flat basin slopes from the north at an elevation of approximately 1,402 meters $(\mathrm{m})(4,600$ feet [ft]) above mean sea level (AMSL) to the south toward Yucca Playa, with the lowest part of the

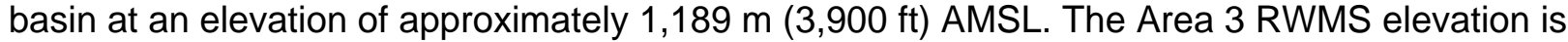
$1,223 \mathrm{~m}(4,012 \mathrm{ft})$. Yucca Flat was one of several primary underground nuclear test areas, and much of the length of the valley is marked with subsidence craters (NSTec, 2007a).

The unsaturated zone at the Area 3 RWMS is estimated to be approximately $488 \mathrm{~m}(1,600 \mathrm{ft})$ thick (BN, 1998), and the water table is assumed to occur in Tertiary tuff. The alluvium thickness is estimated between 370 and $460 \mathrm{~m}$ (1,200 and 1,500 ft) (BN, 2005b).

Based on a 21-year record from 1981 to 2001 at location Buster-Jangle Y (BJY) (4.5 km [2.8 mi] northwest of the Area 3 RWMS), typical daily air temperatures vary from -3 degrees Celsius $\left({ }^{\circ} \mathrm{C}\right)$ (26 degrees Fahrenheit [ $\left.\left.{ }^{\circ} \mathrm{F}\right]\right)$ to $12^{\circ} \mathrm{C}\left(54^{\circ} \mathrm{F}\right)$ during the winter months of December, January, and February and from $14^{\circ} \mathrm{C}\left(57^{\circ} \mathrm{F}\right)$ to $34^{\circ} \mathrm{C}\left(94^{\circ} \mathrm{F}\right)$ during the summer months of June, July, and August. The average winter temperature is $4^{\circ} \mathrm{C}\left(40^{\circ} \mathrm{F}\right)$ and the average summer temperature is $24^{\circ} \mathrm{C}\left(75^{\circ} \mathrm{F}\right)$. During this 21 -year period, the maximum observed temperature was $43.3^{\circ} \mathrm{C}\left(110^{\circ} \mathrm{F}\right)$ and the minimum observed temperature was $-20^{\circ} \mathrm{C}\left(-4^{\circ} \mathrm{F}\right)$. Average relative humidity is $53 \%$ at $4: 00$ Pacific Standard Time (PST), $28 \%$ at $10: 00$ PST, $26 \%$ at 16:00 PST, and $45 \%$ at 22:00 PST. January has the highest relative humidity of $67 \%$ at 4:00 PST, 42\% at 10:00 PST, 43\% at 16:00 PST, and 62\% at 22:00 PST. July has the lowest relative humidity of $40 \%$ at $4: 00$ PST, $19 \%$ at $10: 00$ PST, $17 \%$ at $16: 00$ PST, and $30 \%$ at $22: 00$ PST. The maximum wind gust observed at BJY during this 21-year period was 29.3 meters per second (m/s) (65.6 miles per hour [mph]) in 1987 (Soule, 2006). The average annual precipitation at BJY during the 52-year period from 1961 through 2012 is 160.8 millimeters $(\mathrm{mm})$ (6.33 inches [in.]). Typically low intensity, longer duration storms occur during the winter, and thunderstorms occur during the late summer. February has the most precipitation, and June has the least precipitation (Air Resources Laboratory, Special Operations and Research Division [ARL/SORD], 2013). Annual reference evapotranspiration ( $\mathrm{ET}_{\text {ref }}$ ) at the Area 3 RWMS, calculated using local meteorology data, is approximately 10 times the annual average precipitation (Desotell et al., 2007). 


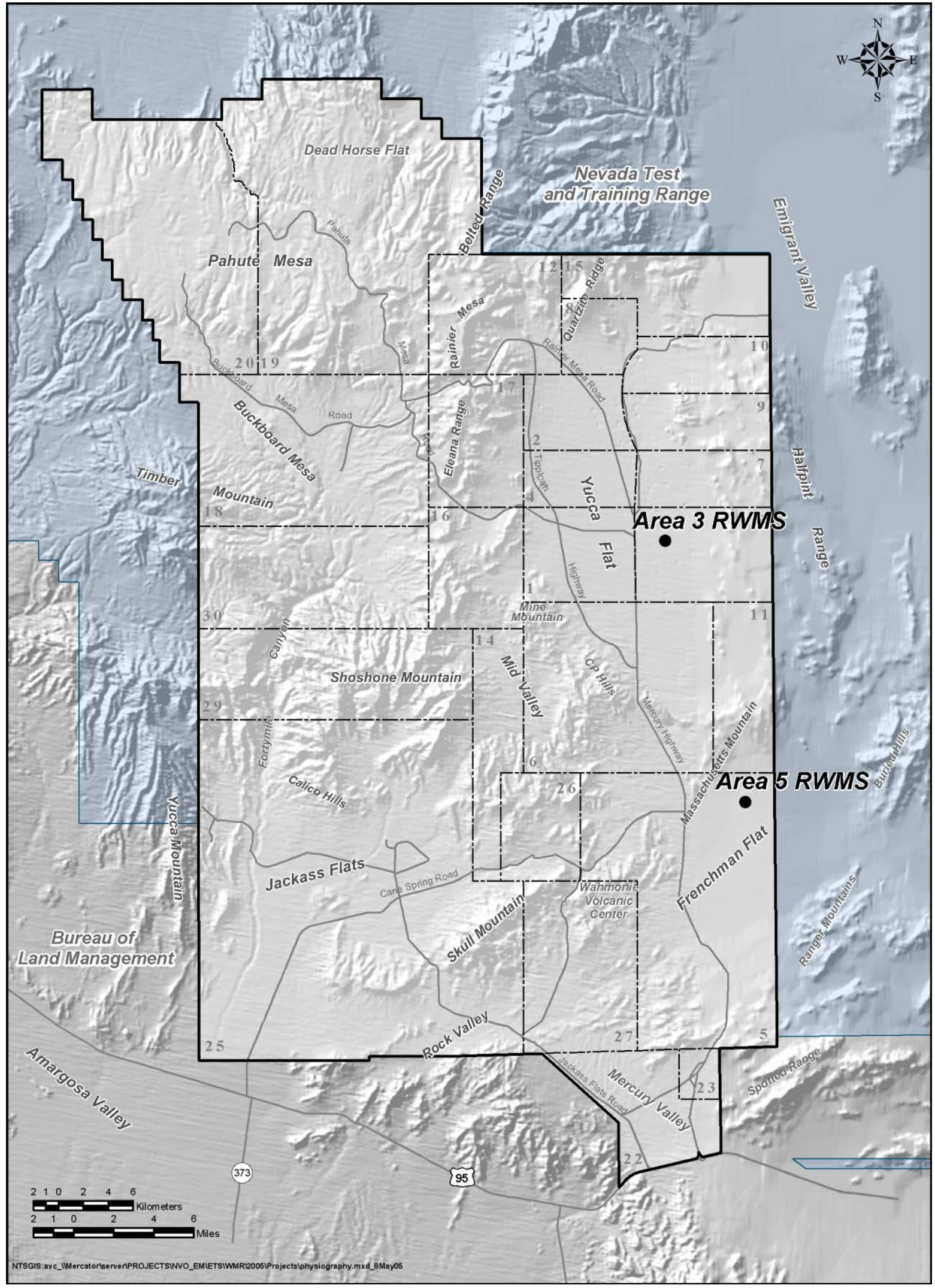

Figure 2-1 Location of the Area 3 and Area 5 RWMSs 


\subsection{AREA 5 RWMS}

The Area 5 RWMS is located on northern Frenchman Flat at the juncture of three coalescing alluvial fan piedmonts (Snyder et al., 1995). Frenchman Flat is a closed intermontane basin located in the southeastern portion of the NNSS. Frenchman Flat is bound by the Massachusetts Mountains and the Halfpint Range on the north, the Buried Hills on the east, the Spotted Range on the south, and the Wahmonie Volcanic Center on the west (Figure 2-1). The valley floor slopes gently toward a central playa (BN, 2006). Ground surface elevations range

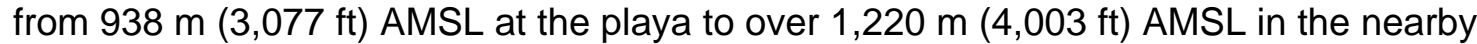
surrounding mountains. The Area 5 RWMS elevation is $962 \mathrm{~m}(3,156 \mathrm{ft})$.

The thickness of the unsaturated zone at the Area 5 RWMS is $235.9 \mathrm{~m}(773.9 \mathrm{ft})$ at the southeast corner of the RWMS (Well UE5PW-1), $256.5 \mathrm{~m}(841.5 \mathrm{ft}$ ) at the northeast corner (Well UE5PW-2), and $271.6 \mathrm{~m}$ (891.1 ft) to the northwest of the RWMS (Well UE5PW-3). Wells UE5PW-1 and UE5PW-2 penetrate only alluvium, while Well UE5PW-3 encounters

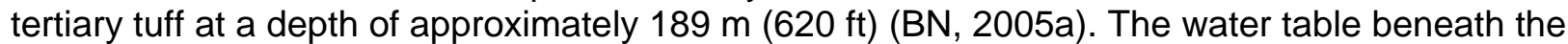
Area 5 RWMS is extremely flat with flow velocities of less than $0.1 \mathrm{~m} /$ year $(0.33 \mathrm{ft} /$ year $)$. The average groundwater elevation measured at these wells in 2012 is $733.6 \mathrm{~m}(2,406.8 \mathrm{ft})$ AMSL.

Based on a 21-year record from 1981 to 2001 at location Well 5B (6.4 km [4 mi] south of the Area 5 RWMS), typical daily air temperatures vary from $-4^{\circ} \mathrm{C}\left(25^{\circ} \mathrm{F}\right)$ to $14^{\circ} \mathrm{C}\left(57^{\circ} \mathrm{F}\right)$ during the winter months of December, January, and February and from $15^{\circ} \mathrm{C}\left(59^{\circ} \mathrm{F}\right)$ to $37^{\circ} \mathrm{C}\left(99^{\circ} \mathrm{F}\right)$ during the summer months of June, July, and August. The average winter temperature is $5^{\circ} \mathrm{C}\left(41^{\circ} \mathrm{F}\right)$ and the average summer temperature is $26^{\circ} \mathrm{C}\left(79^{\circ} \mathrm{F}\right)$. During this 21 -year period, the maximum observed temperature was $46^{\circ} \mathrm{C}\left(115^{\circ} \mathrm{F}\right)$ and the minimum observed temperature was $-21^{\circ} \mathrm{C}$ $\left(-6^{\circ} \mathrm{F}\right)$. Average relative humidity is $46 \%$ at $4: 00 \mathrm{PST}, 25 \%$ at 10:00 PST, $20 \%$ at 16:00 PST, and $37 \%$ at $22: 00$ PST. January has the highest relative humidity of $65 \%$ at $4: 00$ PST, $46 \%$ at 10:00 PST, $34 \%$ at $16: 00$ PST, and $58 \%$ at 22:00 PST. June has the lowest relative humidity of $32 \%$ at $4: 00$ PST, $14 \%$ at $10: 00$ PST, $12 \%$ at $16: 00$ PST, and $21 \%$ at $22: 00$ PST. The maximum wind gust observed at Well 5B during this 21-year period was $29.8 \mathrm{~m} / \mathrm{s}(66.7 \mathrm{mph})$ in 1988 (Soule, 2006). The average annual precipitation at Well 5B during the 49-year period from 1964 through 2012 is $122.4 \mathrm{~mm}$ (4.82 in.). Typically low intensity, longer duration storms occur during the winter, and thunderstorms occur during the late summer. February has the most precipitation, and June has the least precipitation (ARL/SORD, 2013). Annual $E T_{\text {ref }}$ at the Area 5 RWMS, calculated using local meteorology data, is approximately 12 times the annual average precipitation (Desotell et al., 2006).

Areas 3 and 5 are similar, except for slight differences in air temperature, precipitation, and soil texture. Area 3 receives approximately 30\% more rainfall than Area 5, and the annual average temperature at Area 3 is about $2^{\circ} \mathrm{C}\left(4^{\circ} \mathrm{F}\right)$ cooler than at Area 5.

\subsection{HYDROLOGIC CONCEPTUAL MODEL OF THE AREA 3 AND AREA 5 RWMS}

Climate and vegetation strongly control the water movement in the upper few meters of alluvium at both RWMSs. The magnitude and direction of both liquid and vapor fluxes vary seasonally and often daily. Except for periods following precipitation events, water content values in the near-surface are quite low. Below the dynamic near-surface is a region where relatively steady upward water movement is occurring. In this region of slow upward flow, stable isotope compositions of soil water confirm that evaporation (E) is the dominant process (Tyler et al., 1996). The upward flow region extends to depths from approximately 3 to $49 \mathrm{~m}$ (10 to $160 \mathrm{ft}$ ) in Area 3, and from approximately 3 to $40 \mathrm{~m} \mathrm{(10} \mathrm{to} 131 \mathrm{ft}$ ) in Area 5. Below the upward flow region, 
water potential measurements indicate the existence of a static region. The hydraulic gradient in the static region is zero. The static region is between approximately 49 and $119 \mathrm{~m}$ (160 to $390 \mathrm{ft}$ ) deep in Area 3, and between approximately 40 and $90 \mathrm{~m}$ (131 to $295 \mathrm{ft}$ ) deep in Area 5 (Shott et al., 1997; 1998). In the static region, essentially no vertical liquid flow is currently occurring. Below the static region, flow is steady and downward due to gravity (Figure 2-2). Stable isotope compositions of soil water from these depths indicate that infiltration into this zone occurred under cooler past climatic conditions (Tyler et al., 1996). If water were to migrate below the current static zones, movement to the groundwater would be extremely slow due to the low water content of the alluvium. Estimates of travel time to the groundwater (assuming zero upward flux), based on hydraulic characteristics of the alluvium, and assuming that current conditions would still apply, are in excess of 500,000 years in Area 3 (Levitt and Yucel, 2002) and 50,000 years in Area 5 (Shott et al., 1998).

Based on the results of extensive research, field studies, modeling efforts, and monitoring data, which are summarized in the Area 3 and Area 5 PAs (Shott et al., 1997; 1998; Levitt et al., 1999; Levitt and Yucel, 2002; Desotell et al., 2006), groundwater recharge is not occurring under current climatic conditions at the RWMSs. Studies indicate that under bare-soil conditions, such as those found at the operational waste cell covers, some drainage may eventually occur through the waste covers into the waste zone. This drainage is estimated to be about $8 \%$ of the annual rainfall at Area 5 , based on one-dimensional modeling results (Desotell et al., 2006).

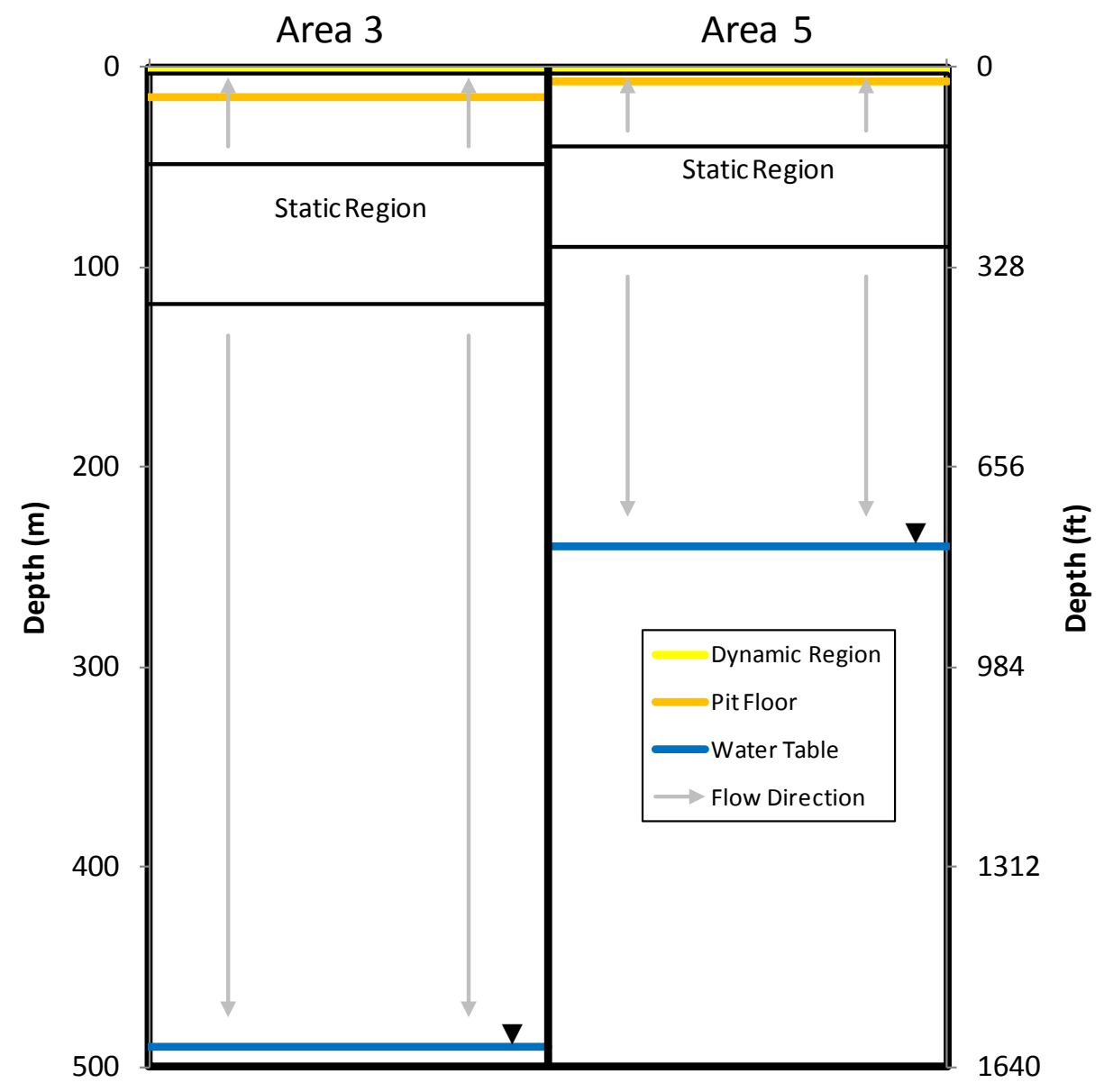

Figure 2-2 Vadose Zone Conceptual Models of the Area 3 and Area 5 RWMSs 


\subsection{PROJECT DESCRIPTION}

The Area 3 and Area 5 RWMSs are designed and operated for the disposal of radioactive low-level waste (LLW) and mixed low-level waste (MLLW) that is generated the NNSS, from DOE offsite locations, and from other approved offsite generators.

\subsection{AREA 3 RWMS}

The Area 3 RWMS covers 48 hectares (119 acres) and includes seven subsidence craters from underground nuclear testing. The seven craters at the Area 3 RWMS are U-3ax, U-3bl, U-3ah, $\mathrm{U}-3 \mathrm{at}, \mathrm{U}-3 \mathrm{bh}, \mathrm{U}-3 \mathrm{az}$, and $\mathrm{U}-3 \mathrm{bg}$. At the time of formation, these seven craters ranged from 122 to $177 \mathrm{~m}$ (400 to $580 \mathrm{ft}$ ) in diameter and from 14 to $32 \mathrm{~m} \mathrm{(46} \mathrm{to} 105 \mathrm{ft}$ ) in depth (Plannerer, 1996). Five of these subsidence craters were developed into three waste disposal units. Alluvium between craters $U-3 a x$ and $U-3 b l$ and between craters $U-3 a h$ and $U-3 a t$ was excavated to form two large disposal units (U-3ax/bl and U-3ah/at). Crater U-3bh is also used for waste disposal. The remaining two craters are not used for waste disposal (Figure 3-1).

U-3bh and U-3ah/at are operational and can accept unclassified LLW but have not received any waste since 2006. U-3bh was originally used for disposal of contaminated soils from the Tonopah Test Range during 1997 and was later used for waste disposal from other approved generators. Disposal in U-3ah/at began in 1988 and has been used for disposal of bulk LLW from the NNSS and approved offsite generators.

U-3ax/bl received unclassified LLW and potential MLLW) from 1968 to 1987 . Disposal in the U-3ax crater began in the late 1960s, and disposal in U-3bl began in 1984. Waste forms consisted primarily of contaminated soil and scrap metal, with some construction debris, equipment, and containerized waste. U-3ax/bl was closed in 2000 by constructing an engineered, monolayer, vegetated, evapotranspiration (ET) cover under the Federal Facility Agreement and Consent Order between the Nevada Division of Environmental Protection and DOE. U-3ax/bl is identified as Corrective Action Unit [CAU] 110 and is permanently closed under the Resource Conservation and Recovery Act (RCRA) as a hazardous waste landfill. The RCRA equivalent cover is constructed of native alluvium at least $2.4 \mathrm{~m}(8 \mathrm{ft})$ thick planted with native plants. For details of the closure of CAU 110, refer to U.S. Department of Energy, Nevada Operations Office (2000; 2001) and BN (2001).

For a detailed description of the facilities at the Area 3 RWMS, refer to Shott et al. (1997) and NSTec (2007a). 


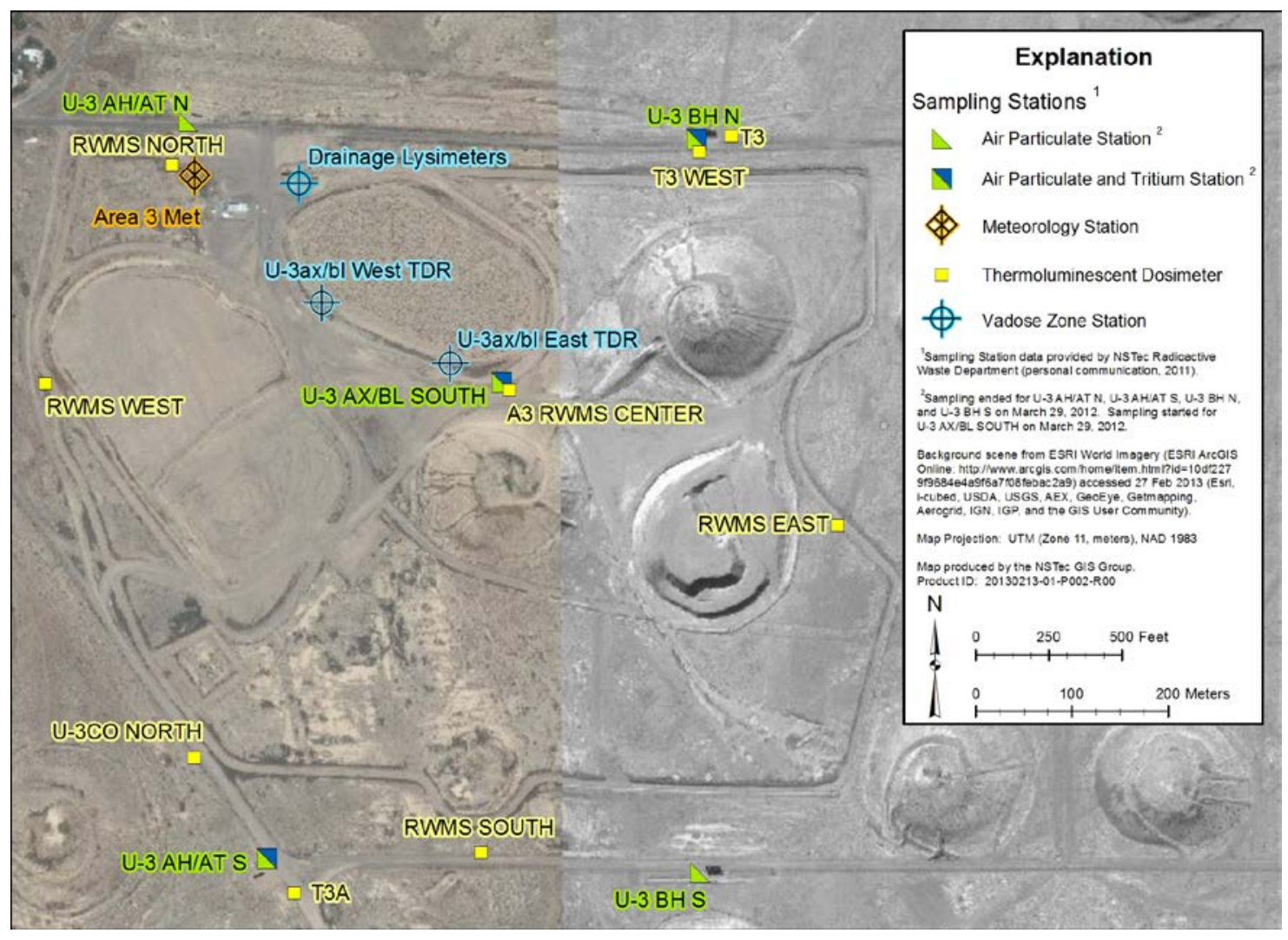

Figure 3-1 Monitoring Locations at the Area 3 RWMS

\subsection{AREA 5 RWMS}

The Area 5 RWMS covers 296 hectares (732 acres) and consists of 38 disposal cells (pits and trenches) and 13 greater confinement disposal (GCD) boreholes (Figure 3-2). The excavated disposal cells range in depth from 4.6 to $15 \mathrm{~m}$ (15 to $48 \mathrm{ft}$ ). Pit 18 (P18) was built with a RCRA compliant double liner and leachate collection system over a geosynthetic clay liner. All other

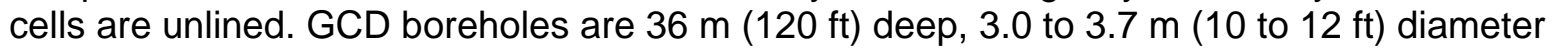
uncased boreholes.

Waste disposal has occurred at the Area 5 RWMS since the early 1960s. Initially LLW and MLLW from the demolition of nuclear test sites and facilities at the NNSS were buried at the Area 5 RWMS. In 1978, DOE formally established the Area 5 RWMS, and it became a disposal site for other DOE complex facilities. During the 1980s the GCD boreholes were constructed and received high specific activity LLW and transuranic waste.

Currently, the disposal units receive sealed waste containers. Containers are stacked to

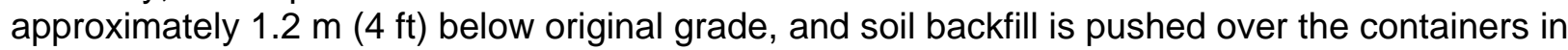

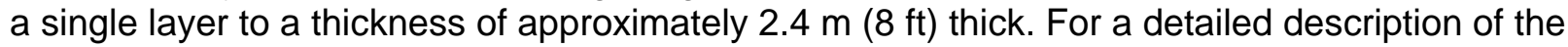
facilities at the Area 5 RWMS, refer to Shott et al. (1998). For further descriptions of pits, trenches, and GCD boreholes, refer to BN (2005c; 2006) and Cochran et al. (2001). 
The approximately 92-Acre Area in the southern portion of the Area 5 RWMS was permanently closed by constructing an engineered, monolayer, vegetated ET cover with a minimum $2.5 \mathrm{~m}$ $(8.2 \mathrm{ft})$ thickness over the waste cells. After grading and soil preparation was completed, the cover surface was disked and seeded with a mixture of native species from October to December 2011. Construction was completed in January 2012. A solid set irrigation system was installed on the cover, and irrigation was applied during seed germination in the spring and fall of 2012 (Goodrich, 2010; U.S. Department of Energy, National Nuclear Security Administration Nevada Site Office [NNSA/NSO], 2010; 2012; The Delphi Groupe and J. A. Cesare and Associates, 2012).

The engineered ET cover within the 92-Acre Area is approximately 18.2 hectares (45 acres). This area is identified as CAU 111. The 92-Acre Area ET cover closed 9 pits (P01, P02, P03, P04, P05, P06, P07, P09, and P11), 16 trenches (T01B, T02B, T03B, T04B, T06B, T07B, T01A, T02A, T03A, T04A, T04A-1, T05, T06A, T07A, T08, and T09),12 GCD boreholes (GCD-01, GCD-02, GCD-03, CGD-04, GCD-05, GCD-06, GCD-07, GCD-08, GCD-09, GCD-10, GCD-11, and GCD-12), and the CWI Trenches. P26 was also closed by the ET cover, but it is completely within P03. Three cells outside the 92-Acre Area (P08, P13, and P15) are operationally closed.

During 2012, waste was disposed in nine cells at the Area 5 RWMS: P12, P14, P16, P17, P18, P19, P20, P21, and T13. All active cells contain LLW, and P18 also contains MLLW. 


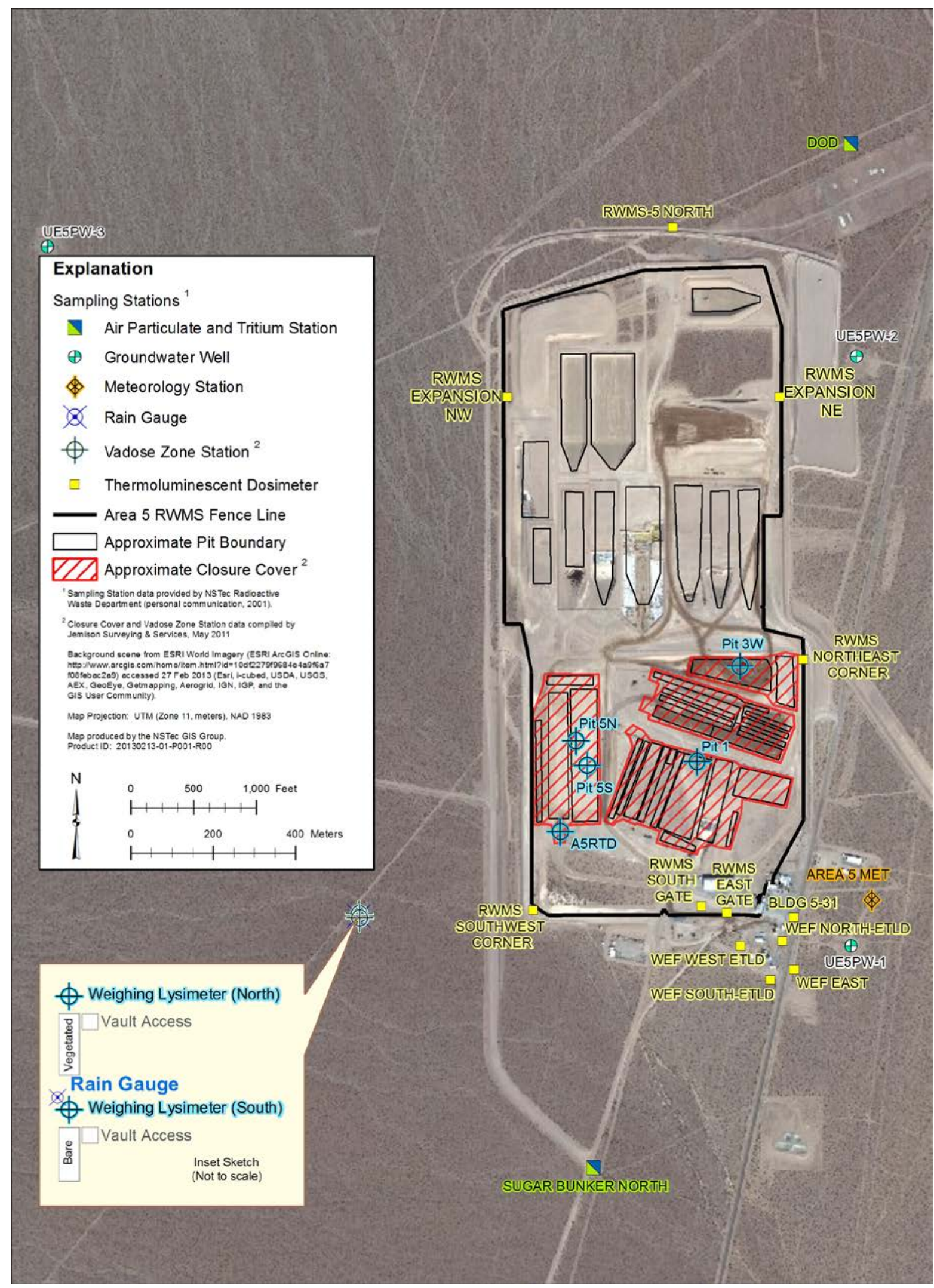

Figure 3-2 Monitoring Locations at the Area 5 RWMS 


\subsection{ENVIRONMENTAL MONITORING DATA}

\subsection{TYPES OF ENVIRONMENTAL MONITORING DATA}

Area 3 RWMS monitoring locations are shown in Figure 3-1, and Area 5 RWMS monitoring locations are shown in Figure 3-2. A summary of the types of environmental monitoring data at the Area 3 RWMS is provided in Table 4-1, and a summary of the types of environmental monitoring at the Area 5 RWMS is provided in Table 4-2. This report provides a general description and graphical representations of some of these data.

There were changes to the monitoring program during 2012. Beginning in April 2012, the air monitoring sample collection interval was increased from 1 week to 2 weeks, and air particulate samples for analysis were decreased from 1 month composites to 3 month composites. Also, air monitoring at the Area 3 RWMS were decreased from four locations at the corners of the Area 3 RWMS (U-3ahat N, U-3ahat S, U-3bh N, and U-3bh South) to one location in the center of the Area 3 RWMS (U-3ax/bl South) (see Figure 3-1). At the Area 5 RWMS, radiation monitoring at location RWMS Northwest Corner was discontinued and was replaced with the radiation monitoring location RWMS-5 North (see Figure 3-2). 
Table 4-1 Environmental Monitoring at the Area 3 RWMS

\begin{tabular}{|c|c|}
\hline Monitoring & Description \\
\hline $\begin{array}{l}\text { Radiation } \\
\text { Exposure }\end{array}$ & $\begin{array}{l}\text { - 3-month measurement interval at } 9 \text { locations } \\
\text { - Thermoluminescent dosimeter (TLD) measurements of total radiation } \\
\text { exposure }\end{array}$ \\
\hline Air & $\begin{array}{l}\text { - 2-week sample interval at } 1 \text { location inside Area } 3 \text { RWMS } \\
\text { - } \quad \text { Tritium concentration in atmospheric moisture } \\
\text { - } \quad \text { Gross alpha and beta concentration of particulates } \\
\text { - } \quad \text { Air particulate analysis on quarterly composites-gamma-emitting } \\
\text { radionuclides, americium (Am), and plutonium (Pu) concentrations }\end{array}$ \\
\hline Radon Flux & $\begin{array}{l}\text { - } \quad \text { Periodic radon flux measurements } \\
\text { - } \quad \text { Various locations on waste covers }\end{array}$ \\
\hline Meteorology & $\begin{array}{l}\text { - } \text { Daily and hourly measurements at } 1 \text { location } \\
\text { - } \text { Air temperature at } 3.0 \mathrm{~m} \text { and } 9.5 \mathrm{~m} \\
\text { - } \text { Relative humidity at } 3.0 \mathrm{~m} \text { and } 9.5 \mathrm{~m} \\
\text { - } \text { Vapor pressure at } 3.0 \text { and } 9.5 \mathrm{~m} \\
\text { - } \text { Wind speed and direction at } 3.0 \text { and } 9.5 \mathrm{~m} \\
\text { - } \text { Barometric pressure } \\
\text { - Precipitation-hourly, daily, and } 5 \text {-minute rate } \\
\text { - Solar radiation } \\
\text { - Energy balance for ET calculation-net solar radiation, soil heat flux, soil } \\
\text { temperature, soil water content }\end{array}$ \\
\hline Vadose Zone & $\begin{array}{l}\text { - Drainage lysimeters } \\
\text { - } 8 \text { lysimeters at } 1 \text { location } \\
\text { - } 3 \text { vegetation treatments (bare soil, invader species, and native species) } \\
\text { with } 2 \text { irrigation treatments (precipitation and 3-times precipitation) } \\
\text { - Daily and hourly measurements at each lysimeter-drainage, water } \\
\text { content, water potential, and temperature } \\
\text { - Daily water content profiles in final U-3ax/bl cover at } 4 \text { locations }\end{array}$ \\
\hline Biota & $\begin{array}{l}\text { - Periodic sampling of vegetation, small mammals, and animal burrow } \\
\text { spoils for tritium and radionuclides } \\
\text { - Annual plant density and plant cover measurements on each drainage } \\
\text { lysimeter and the U-3ax/bl cover }\end{array}$ \\
\hline Subsidence & $\begin{array}{l}\text { - } 8 \text { surveyed subsidence monuments on U-3ax/bl cover with 2-year } \\
\text { measurement interval } \\
\text { - Cover inspections at 3-month interval }\end{array}$ \\
\hline
\end{tabular}


Table 4-2 Environmental Monitoring at the Area 5 RWMS

\begin{tabular}{|c|c|}
\hline Monitoring & Description \\
\hline $\begin{array}{l}\text { Radiation } \\
\text { Exposure }\end{array}$ & $\begin{array}{l}\text { - 3-month measurement interval at } 12 \text { locations } \\
\text { - } \quad \text { TLD measurements of total radiation exposure }\end{array}$ \\
\hline Air & $\begin{array}{l}\text { - 2-week sample interval at } 2 \text { locations } \\
\text { - } \quad \text { Tritium concentration in atmospheric moisture } \\
\text { - Gross alpha and beta concentration of particulates } \\
\text { - } \quad \text { Air particulate analysis on quarterly composites-gamma-emitting } \\
\text { radionuclides, Am, and Pu concentrations }\end{array}$ \\
\hline Radon Flux & $\begin{array}{l}\text { - } \quad \text { Periodic radon flux measurements } \\
\text { - } \quad \text { Various locations on waste covers }\end{array}$ \\
\hline Groundwater & $\begin{array}{l}\text { - } 3 \text { wells surrounding Area } 5 \text { RWMS } \\
\text { - Water level measurement at 3-month interval } \\
\text { - Groundwater samples at 6-month interval } \\
\text { - } \quad \text { Analysis for indicators of contamination-Field measurements of pH and } \\
\text { specific conductance (SC), Total organic carbon (TOC), Total Organic } \\
\text { halides (TOX), and Tritium } \\
\text { - Analysis of water chemistry-calcium, magnesium, potassium, sodium, } \\
\text { iron, manganese, sulfate, chloride, fluoride, and silicate } \\
\text { - Alkalinity }\end{array}$ \\
\hline Meteorology & $\begin{array}{l}\text { - } \quad \text { Daily and hourly measurements at } 1 \text { location } \\
\text { - } \quad \text { Air temperature at } 3.0 \mathrm{~m} \text { and } 9.5 \mathrm{~m} \\
\text { - } \quad \text { Relative humidity at } 3.0 \mathrm{~m} \text { and } 9.5 \mathrm{~m} \\
\text { - } \quad \text { Vapor pressure at } 3.0 \text { and } 9.5 \mathrm{~m} \\
\text { - } \quad \text { Wind speed and direction at } 3.0 \text { and } 9.5 \mathrm{~m} \\
\text { - } \text { Barometric pressure } \\
\text { - } \quad \text { Precipitation-hourly, daily, and } 5 \text {-minute rate } \\
\text { - } \quad \text { Solar radiation } \\
\text { - } \quad \text { Energy balance measurements for ET calculation-net solar radiation, } \\
\text { soil heat flux, soil temperature, soil water content }\end{array}$ \\
\hline Vadose Zone & $\begin{array}{l}\text { - } 2 \text { weighing lysimeters-bare soil and vegetated at } 1 \text { location } \\
\text { - Direct measurement of ET } \\
\text { - } \quad \text { Daily water content, water potential, and temperature profiles at each } \\
\text { lysimeter } \\
\text { - } \quad \text { Daily water content, water potential, and temperature profiles in 92-Acre } \\
\text { - } \text { Area cover at } 4 \text { locations } \\
\text { - } \quad \text { Saily water content below closed disposal cell at } 4 \text { locations } \\
\end{array}$ \\
\hline Biota & $\begin{array}{l}\text { - Periodic sampling of vegetation, small mammals, and animal burrow } \\
\text { spoils for tritium, and particulate radionuclides }\end{array}$ \\
\hline
\end{tabular}


Table 4-2 Environmental Monitoring at the Area 5 RWMS (continued)

\begin{tabular}{|l|ll|}
\hline \multicolumn{1}{|c|}{ Monitoring } & \multicolumn{1}{c|}{ Description } \\
\hline Subsidence & $\bullet \begin{array}{l}\text { 52 surveyed subsidence monuments on 92-Acre Area cover at 1-year } \\
\text { measurement interval }\end{array}$ \\
\hline Leachate & $\bullet \quad$ Quarterly subsidence inspections \\
& $\bullet \quad \begin{array}{l}\text { Chemical analysis of P18 MLLW disposal cell leachate } \\
\text { - Sampling and analysis when leachate collection tank is full }\end{array}$ \\
\hline
\end{tabular}

\subsection{RADIATION EXPOSURE DATA}

Direct radiation monitoring assesses and detects changes in the external radiation environment and measures gamma radiation levels near potential exposure sites. Performance objectives in DOE O 435.1 require that LLW disposal facilities be sited, designed, operated, maintained, and closed, so a reasonable, expected, total effective dose equivalent from the facility to a representative member of the public is less than 25 millirem per year (mrem/yr). The effective dose equivalent is from all exposure pathways associated with the facility but does not include the dose from radon or background. The RWMSs are located well within the NNSS boundaries, so the public does not have access to these areas for significant periods of time. However, exposure rates measured by TLDs located at the RWMSs show the potential dose to a hypothetical person residing continuously at the RWMS.

TLDs (Panasonic UD 814AS) are used to measure ionizing radiation exposure from all sources, including natural and man-made radioactivity. These TLDs have three calcium sulfate elements housed in an air-tight, water-tight, ultraviolet-light-protected case. The elements measure the total exposure rate from penetrating gamma radiation including background. The penetrating gamma radiation makes up the deep dose, which is compared to the $25 \mathrm{mrem} / \mathrm{yr}$ limit when background exposure is subtracted.

Figure 3-1 and Figure 3-2 show TLD monitoring locations near the Area 3 and Area 5 RWMSs. A pair of TLDs is placed $1 \pm 0.3 \mathrm{~m}$ (28 to 51 in.) above ground level (AGL) at each location and exchanged for analysis on a quarterly basis. TLDs are analyzed using automated TLD readers that are calibrated and maintained by the NSTec Radiological Control Department. Reference TLDs exposed to 100 milliroentgen $(\mathrm{mR})$ from a cesium-137 $\left({ }^{137} \mathrm{Cs}\right)$ radiation source under controlled conditions are used to scale the response of the measurement TLDs. Direct radiation exposure is usually reported in the unit $\mathrm{mR}$, which is a measure of exposure in terms of numbers of ionizations in air. Generally, the dose in human tissue resulting from an exposure from the most common external radionuclides can be approximated by equating a $1 \mathrm{mR}$ exposure with a 1 millirem (mrem) dose. During the first quarter of 2012, there are no TLD results due to an analysis error. Results from before and after the lost data and air monitoring results discussed in the following section do not indicate any impacts from operations during the first quarter.

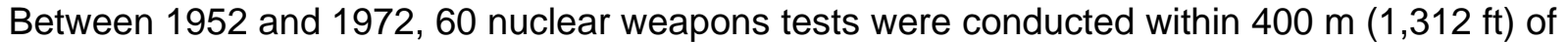
the Area 3 RWMS boundary. Fourteen of these tests were atmospheric tests, which left radionuclide-contaminated surface soil with elevated radiation exposures across the area. Waste pits in the Area 3 RWMS are subsidence craters from seven subsurface tests that are being filled with LLW. During disposal operations, the waste is covered with clean soil, resulting 
in lower exposures inside the Area 3 RWMS when compared with the average exposures at the Area 3 RWMS fence line or in Area 3 outside the fence line.

Annual radiation exposures measured in milliroentgen per year (mR/yr) during 2012 at nine locations inside and near the Area 3 RWMS range from 103 to $311 \mathrm{mR} / \mathrm{yr}$ (Figure 4-1). The Area 3 monitoring locations are (1) inside the Area 3 RWMS (RWMS Center), (2) on the RWMS boundary (RWMS North, RWMS East, RWMS South, RWMS West), and (3) outside the RWMS boundary (T3, T3 West, T3A, and U3CO North) (Figure 3-1). The exposures measured inside the Area 3 RWMS and three of four measurements at the boundary are within the range of background exposures. The four TLD locations outside the Area 3 RWMS boundary and RWMS South (boundary location) have higher exposures due to nearby historical aboveground nuclear weapons tests. This distribution of exposures indicates radionuclides in the Area 3 RWMS have a negligible contribution to total exposure for a hypothetical person residing at the Area 3 RWMS when compared to exposures resulting from historical aboveground nuclear weapons tests. Estimated daily exposure rates in $\mathrm{mR} /$ day from the quarterly exposure rate data at the Area 3 RWMS are within the range of exposure rates at NNSS background locations (Figure 4-2).

Between 1951 and 1971, 25 nuclear weapons tests were conducted within $6.3 \mathrm{~km}$ (3.9 mi) of the Area 5 RWMS. Fifteen of these were atmospheric tests, and nine of the remaining ten tests released radioactivity to the surface. There were no nuclear weapons tests within the boundaries of the Area 5 RWMS. Estimated daily exposure rates from the quarterly exposure data at the Area 5 RWMS are within the range of exposures measured at NNSS background locations (Figure 4-3).

Comparisons of 2003 to 2012 direct radiation exposure data using TLDs from the two RWMSs with direct radiation data from NNSS background locations indicate that direct radiation exposure at the Area 3 and Area 5 RWMSs is generally low or declining (Figure 4-2 and Figure 4-3).

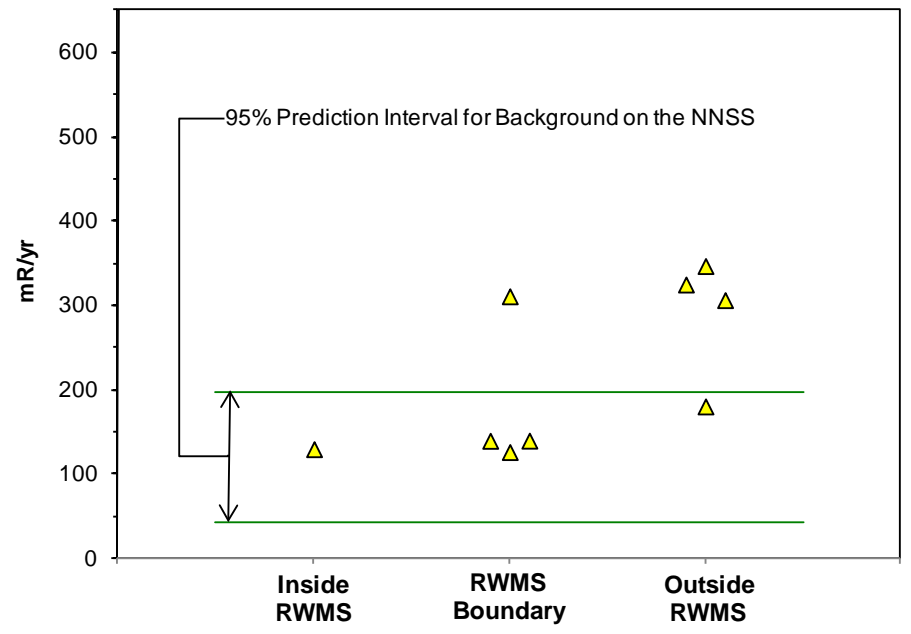

Figure 4-1 Annual Radiation Exposure Rates at the Area 3 RWMS 


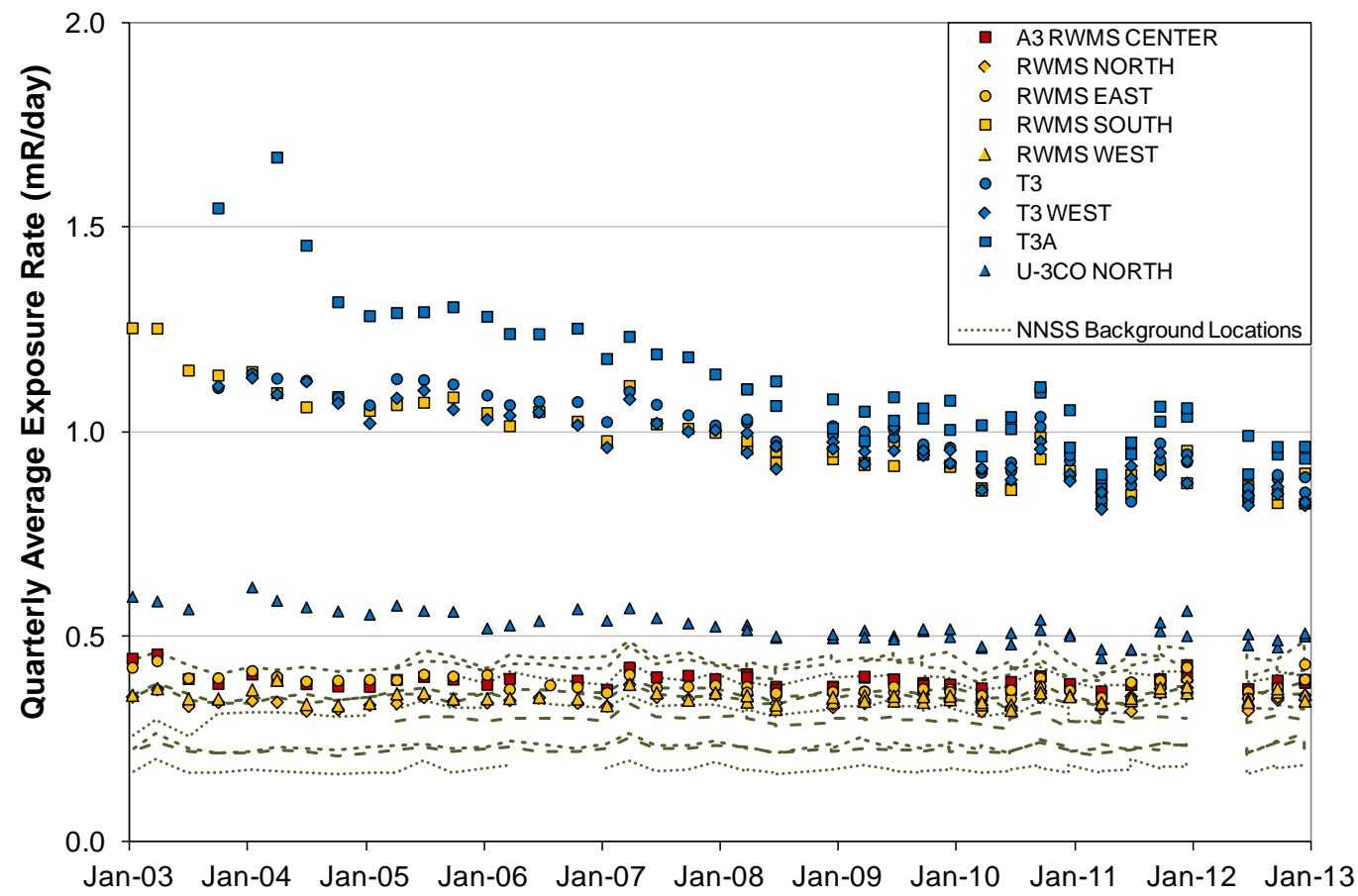

Figure 4-2 Quarterly Average Daily Exposure Rates at the Area 3 RWMS and NNSS Background TLD Locations from 2003 through 2012

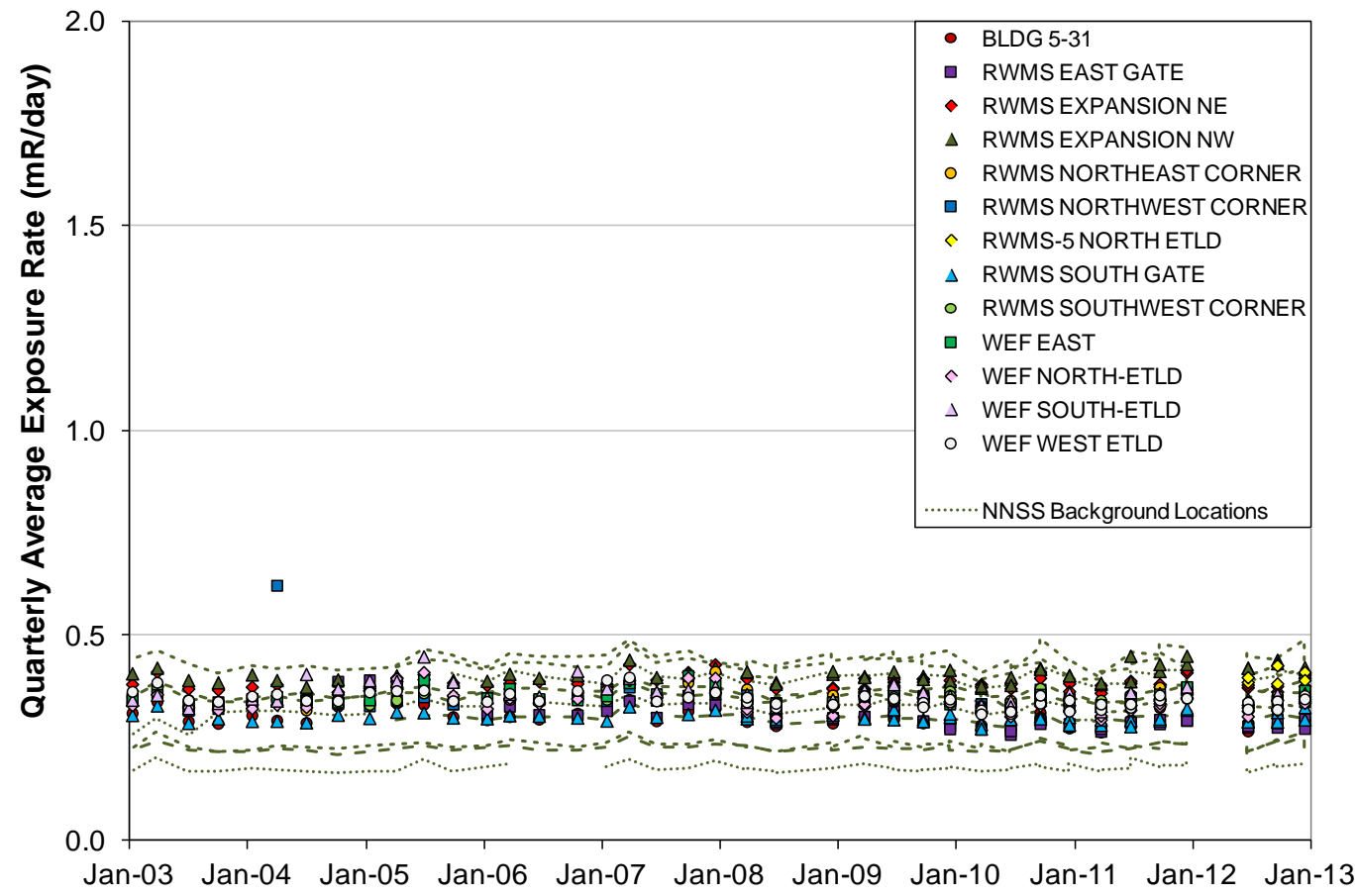

Figure 4-3 Quarterly Average Daily Exposure Rates at the Area 5 RWMS and NNSS Background TLD Locations from 2003 through 2012 


\subsection{AIR MONITORING DATA}

\subsubsection{Tritium}

Tritium is a highly mobile isotope of hydrogen that acts as a conservative tracer. It is an excellent performance indicator of volatile radionuclide migration from waste cells. Atmospheric moisture is continuously collected at the Area 3 and Area 5 RWMSs and analyzed for tritium. Approximately 11 cubic meters $\left(\mathrm{m}^{3}\right)$ (388 cubic feet $\left[\mathrm{ft}^{3}\right]$ ) of air are drawn across a desiccant during each 2-week sample period to collect atmospheric moisture. Moisture is distilled from the desiccant, and tritium activity is measured by liquid scintillation.

Tritium was sampled at five locations near the Area 3 RWMS (Figure 3-1). Sampling at two tritium monitoring locations, U-3bh $\mathrm{N}$ and U-3ah/at $\mathrm{S}$, ended and sampling at three stations (U-3ax/bl South, Bilby Crater, and Kestrel Crater N) started on March 29, 2012 (Figure 3-1). The $\mathrm{U}-3$ bh $\mathrm{N}$ and $\mathrm{U}-3$ ah/at $\mathrm{S}$ samplers were removed because they were located on areas contaminated by past atmospheric nuclear weapons tests, which made sample results less representative of what may have been coming from the RWMS. The U-3ax/bl South sampler was established to measure concentrations of radionuclides near the center of the Area 3 RWMS, so the results should be more representative of what may be coming from the Area 3 RWMS. The Bilby Crater and Kestrel Crater N sampling locations were established at upwind and downwind locations. Bilby Crater is approximately $1.2 \mathrm{~km}(0.75 \mathrm{mi})$ north of the Area 3 RWMS and Kestral Crater $\mathrm{N}$ is approximately $1.5 \mathrm{~km}(0.9 \mathrm{mi})$ south of the Area $3 \mathrm{RWMS}$. Any elevated radionuclide concentrations at U-3ax/bl compared to Bilby Crater and Kestral Crater $\mathrm{N}$ might indicate that the Area 3 RWMS was the source of the elevated radionuclide concentrations. Similar radionuclide concentrations at these three monitoring locations would indicate that the Area 3 RWMS is not a strong source of the radionuclides.

The two Area 5 RWMS monitoring locations are DoD and Sugar Bunker. DoD is approximately $1.0 \mathrm{~km}(0.6 \mathrm{mi})$ north of the Area $5 \mathrm{RWMS}$, and Sugar Bunker is approximately $1.5 \mathrm{~km}(0.9 \mathrm{mi})$ south of the Area 5 RWMS (Figure 3-2). These monitoring locations are in the prevailing downwind directions to provide adequate environmental monitoring for the Area 5 RWMS.

During 2012, tritium concentrations at the Area 3 and Area 5 RWMSs ranged from -0.63 to 2.48 picocuries per cubic meter $\left(\mathrm{pCi} / \mathrm{m}^{3}\right)$. All results were well below the DOE Derived Concentration Standard (DCS) (DOE-STD-1196-2011) for tritium adjusted to the $25 \mathrm{mrem} / \mathrm{yr}$ exposure specified in DOE O 435.1. This scaled DCS is the concentration of tritium in air that would result in a 25 mrem annual effective dose to the person breathing it for the entire year. In general, higher tritium concentrations occurred in September through October, but all concentrations were much lower than the DCS (Figure 4-4). 


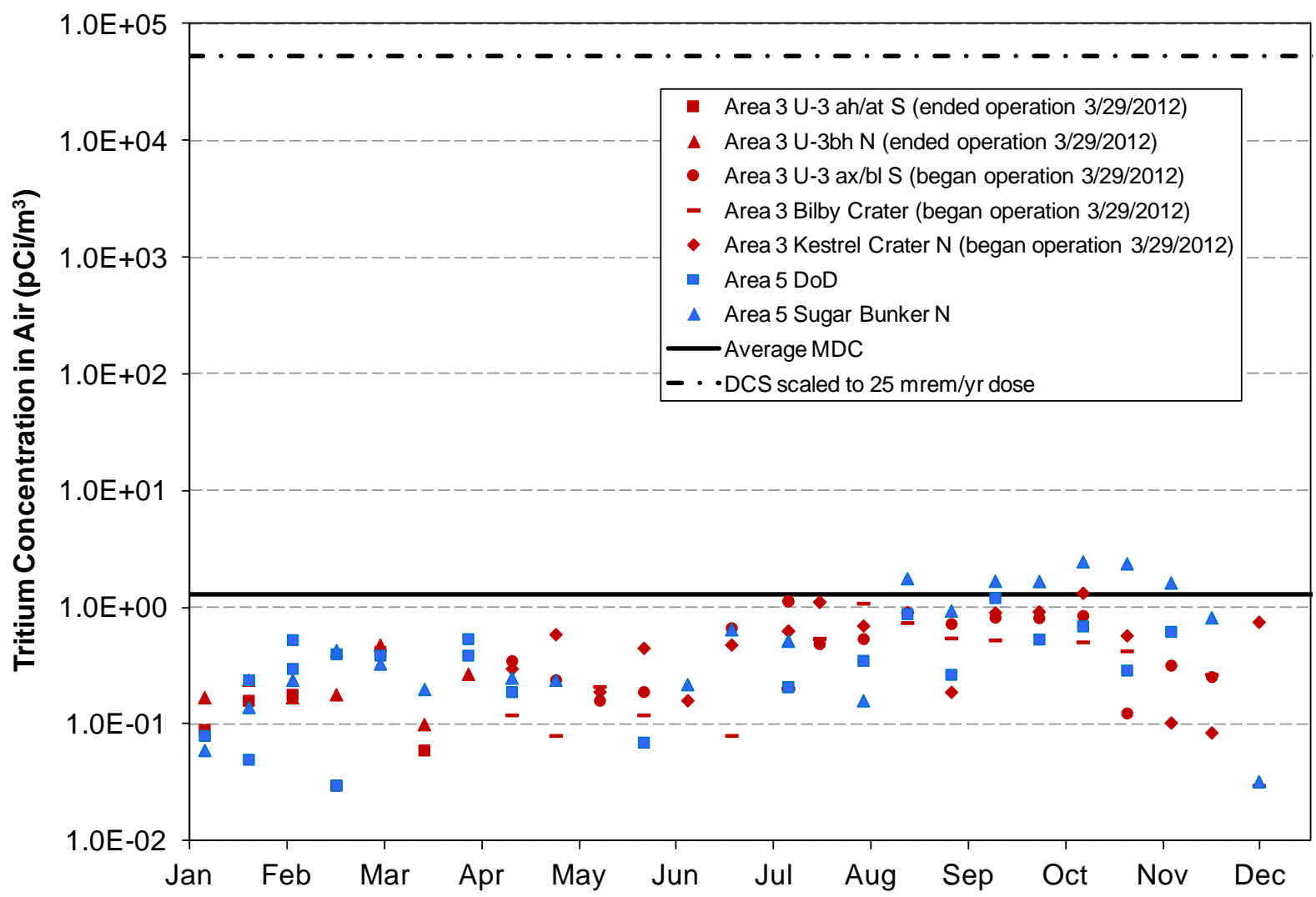

Figure 4-4 Tritium Concentration in Air at the Area 3 and Area 5 RWMSs during 2012

\subsubsection{Particulates}

Air particulate samples were collected weekly from January through March 2012, and biweekly from April through December 2012. Each sample was collected using a vacuum pump to draw approximately $850 \mathrm{~m}^{3}$ of air per week through a glass-fiber filter. The air particulates are collected on the filter. Each filter was screened for gross alpha and gross beta radioactivity. This is done to provide early detection of any change in environmental concentrations of airborne radioactivity. Monthly composites (January through March) and quarterly composites (April through December) of the filters from each sampling location were analyzed by gamma spectroscopy for gamma-emitting radionuclides and by radiochemical analyses for americium and plutonium.

Air particulates were sampled at seven locations near the Area 3 RWMS during 2012 (Figure 3-1). Sampling at four monitoring locations, U-3bh N, U-3bh S, U-3ah/at N, and U-3ah/at S, ended March 29, 2013, and sampling at three new stations, U-3ax/bl South, Bilby Crater, and Kestrel Crater N, started the same day (Figure 3-1). This change was done for the reasons described above for tritium sampling. The two air particulate monitoring locations at the Area 5 RWMS are DoD and Sugar Bunker (Figure 3-2).

The results for ${ }^{241} \mathrm{Am},{ }^{238} \mathrm{Pu}$, and ${ }^{239+240} \mathrm{Pu}$ in air are provided in Figure 4-5, Figure 4-6, and Figure 4-7 respectively. The americium and plutonium concentrations tend to be slightly higher 
at the Area 3 RWMS compared with those at the Area 5 RWMS. There is no indication that RWMS operations contributed americium or plutonium activity above normal variability observed at all locations. All measured concentrations of americium and plutonium were well below the $25 \mathrm{mrem} / \mathrm{yr}$ adjusted DCS for each radionuclide.

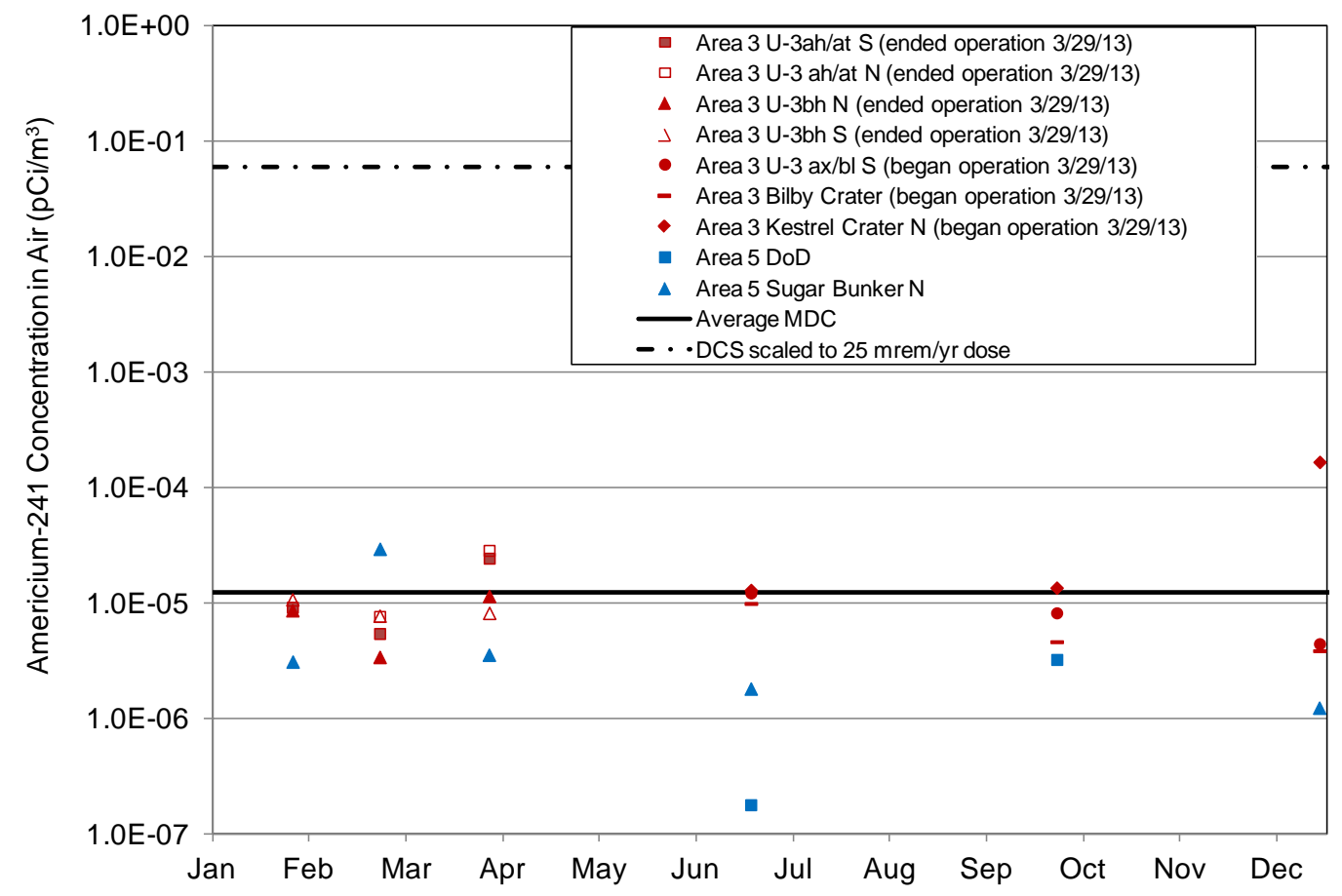

Figure 4-5 Concentration of ${ }^{241} \mathrm{Am}$ in Air at the Area 3 and Area 5 RWMSs during 2012 


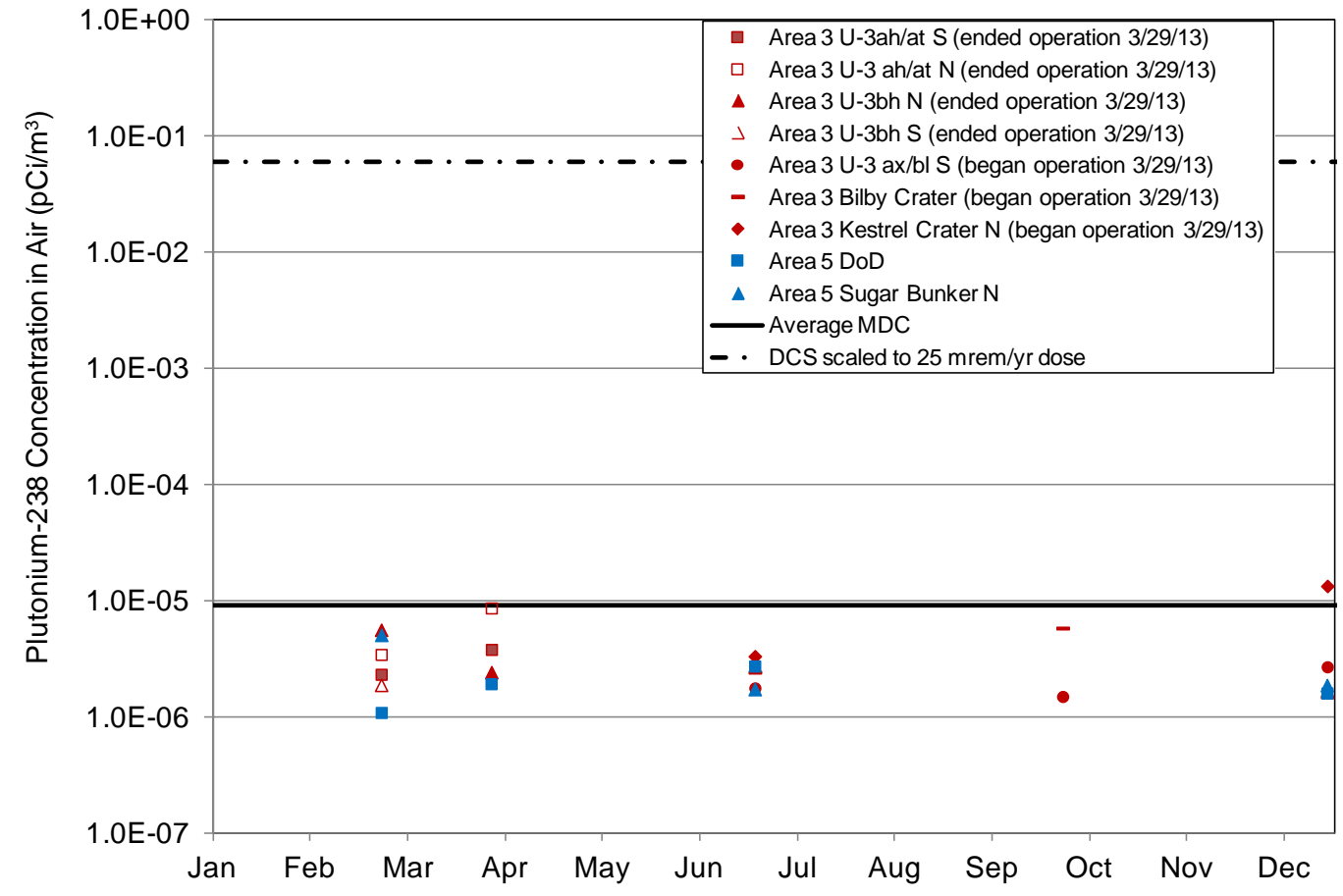

Figure 4-6 Concentration of ${ }^{238} \mathrm{Pu}$ in Air at the Area 3 and Area 5 RWMS during 2012

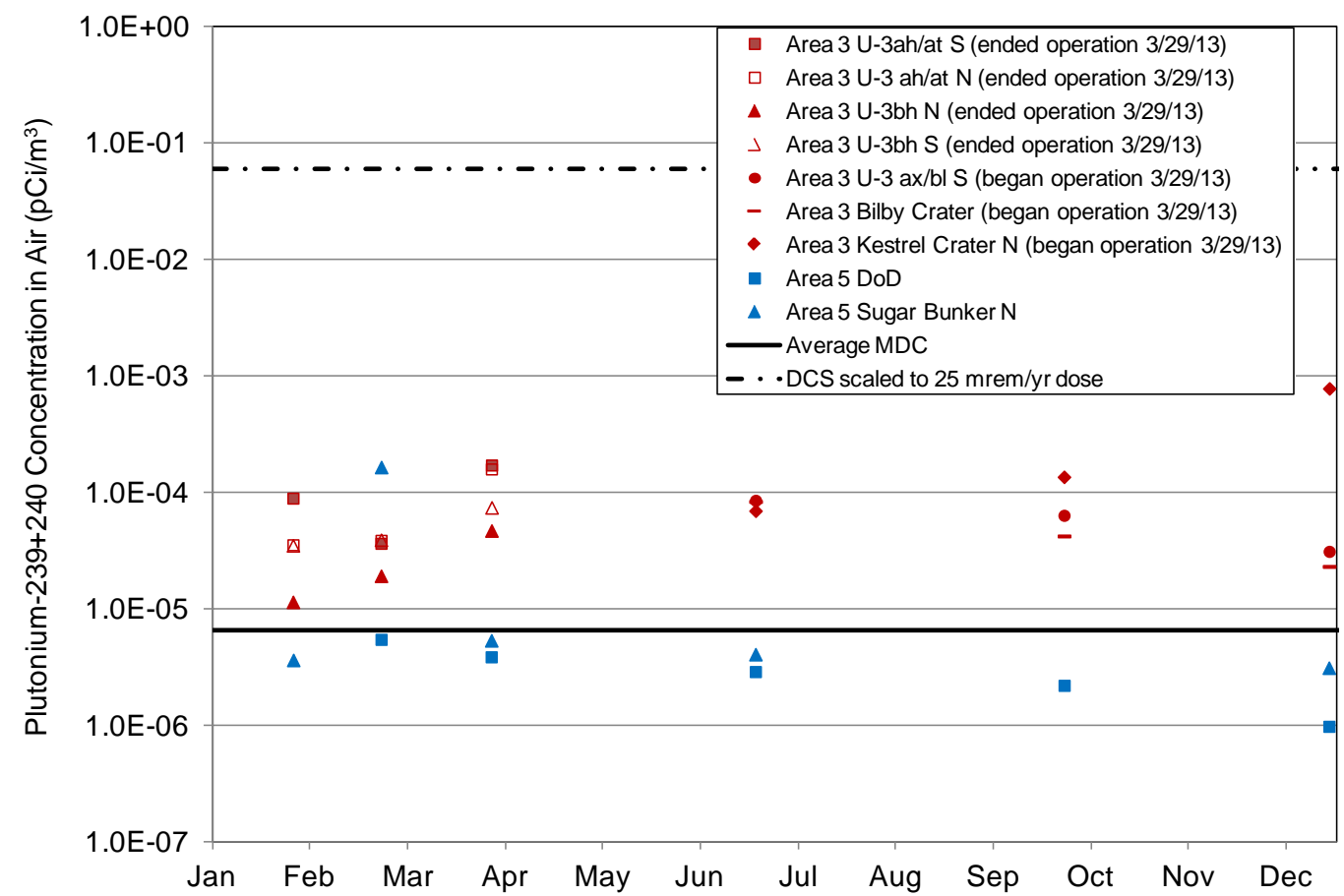

Figure 4-7 Concentration of ${ }^{239+240} \mathrm{Pu}$ in Air at the Area 3 and Area 5 RWMSs during 2012 


\subsubsection{Radon}

The performance objective from DOE Manual DOE M 435.1-1, "Radioactive Waste Management Manual," for radon emissions from DOE radioactive waste facilities is 20 picocuries per square meter per second ( $\left.\mathrm{pCi} / \mathrm{m}^{2} / \mathrm{s}\right)$. Radon flux was measured at multiple locations at the Area 5 RWMS and at an undisturbed, control site outside the Area 5 RWMS during 2012 (Figure 4-8).

Measurements were collected December 19-20, 2012, using radon flux domes (Rad Elec, Inc.) placed on the ground surface. Electrets inserted in the domes are electrically discharged by ionization of air from radon. The amount of discharge is correlated with radon flux from the ground.

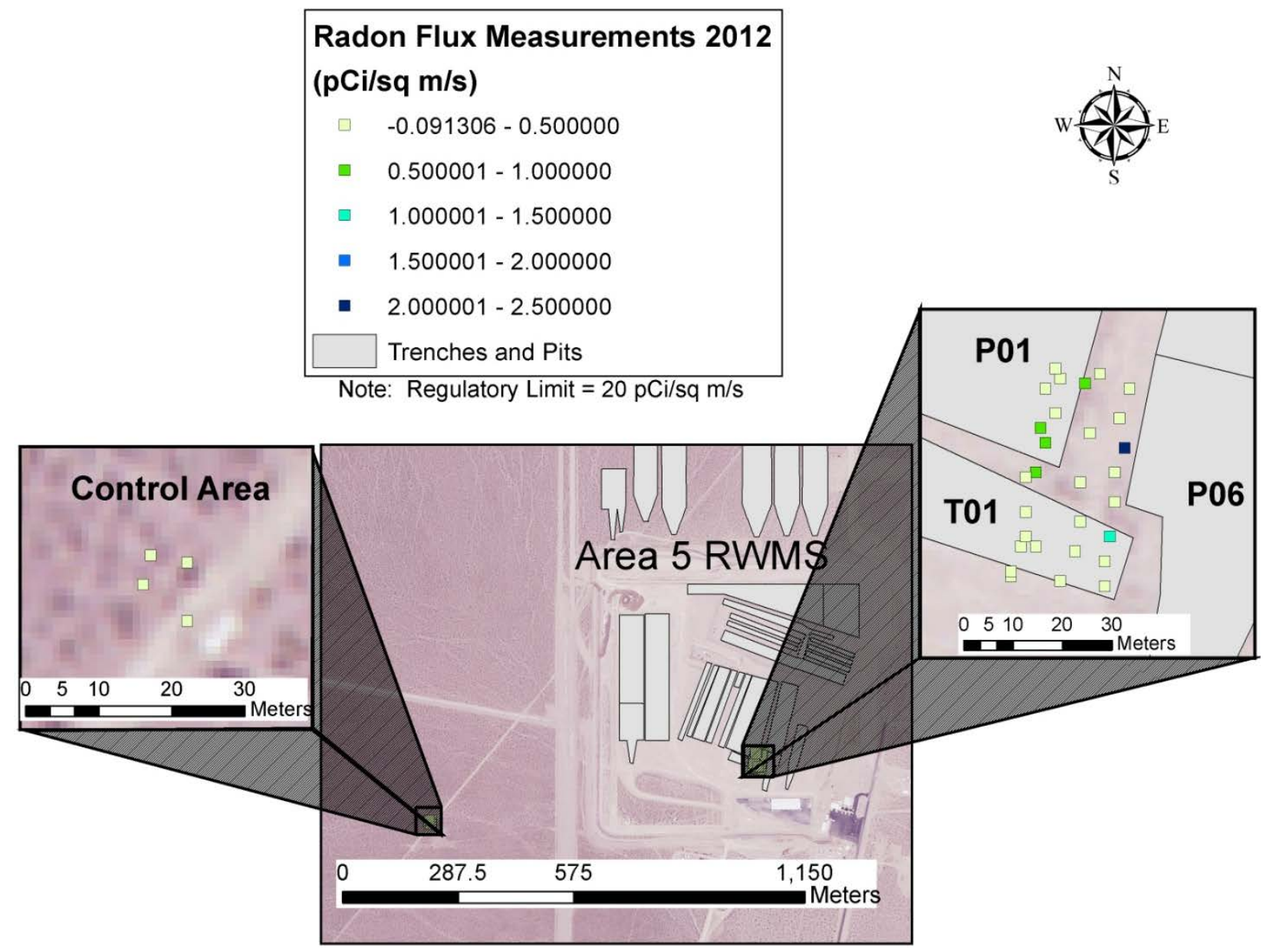

Figure 4-8 Radon Flux Measurement Locations in Area 5 RWMS

Radon flux results taken on both the Area 3 and Area 5 RWMSs over the past 10 years are summarized in Figure 4-9. Radon fluxes through the soil surface remained relatively low. All radon flux results were at least 5 times lower than the regulatory limit, and there are no apparent trends. 


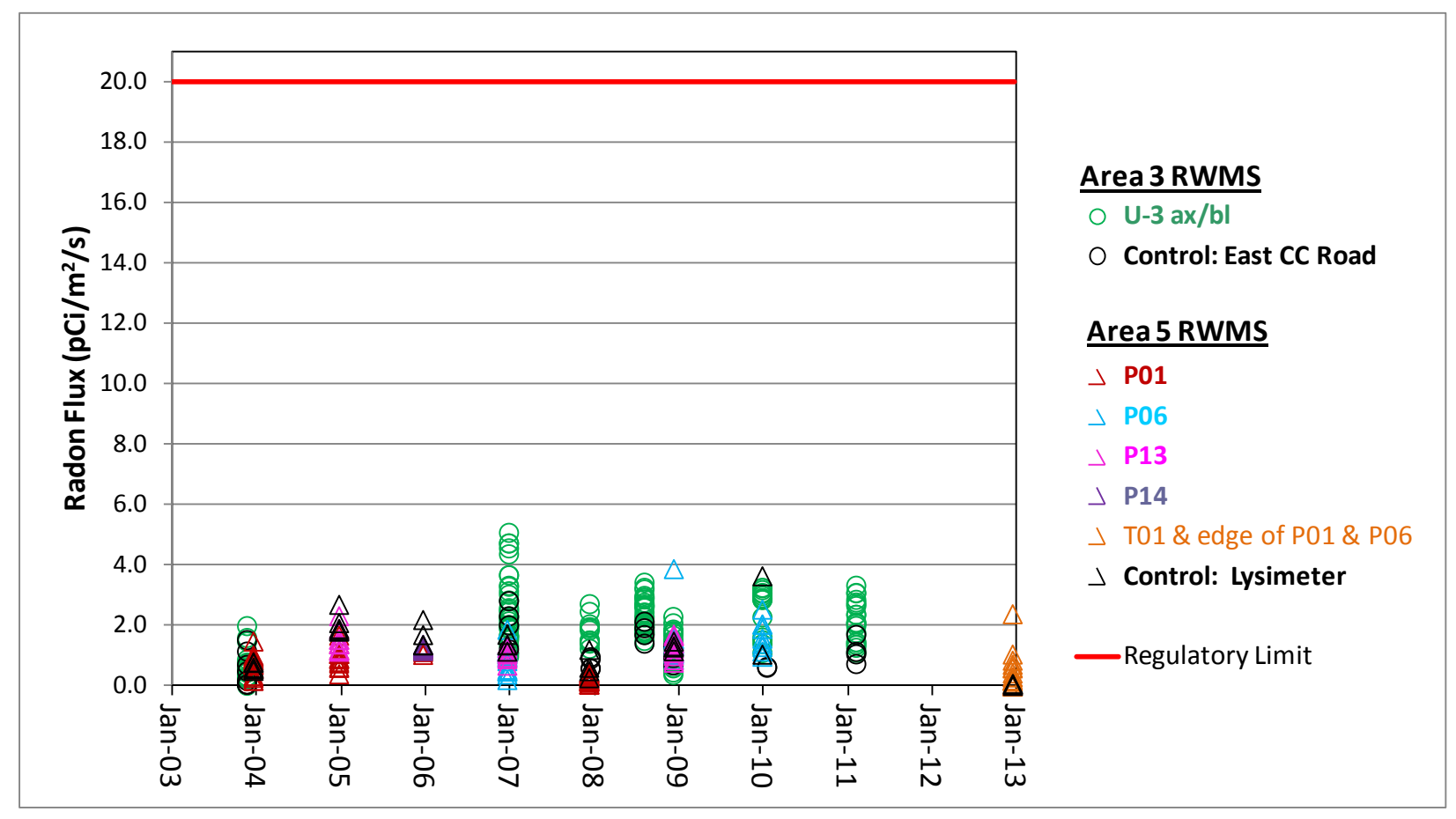

Figure 4-9 Radon Flux Results from 2002 through 2012

\subsection{GROUNDWATER MONITORING DATA}

\subsubsection{Groundwater Monitoring at the Pilot Wells}

Three wells (UE5PW-1, UE5PW-2, and UE5PW-3) were drilled around the perimeter of the Area 5 RWMS in 1993 (see Figure 2-1). These wells are sampled twice a year to monitor the groundwater below the Area 5 RWMS. Initially groundwater samples were collected in March and August 2012. Investigation levels (ILS) have been established for five indicators of contamination migration. The measured indicators are SC, pH, TOC, TOX, and tritium. Further groundwater analyses are required if any analyte exceeds its IL. Initial TOX results from August 2012 were above previous results, and one of three collected samples from UE5PW-3 was slightly above the IL. The initial TOX results for the three samples collected from UE5PW-3 were 18.6 micrograms per liter $(\mu \mathrm{g} / \mathrm{L}), 37.6 \mu \mathrm{g} / \mathrm{L}$, and $50.7 \mu \mathrm{g} / \mathrm{L}$. All three pilot wells were resampled for TOX analysis in September 2012, and all of these TOX results were below the IL. Results from 2012 are summarized in Table 4-3. General water chemistry parameters are also measured.

To date, all analytical data from groundwater sampling events from the wells indicate that the groundwater in the uppermost aquifer is unaffected by activities at the Area 5 RWMS. Detailed information and data on the groundwater monitoring program at the Area 5 RWMS are presented in the Nevada National Security Site 2012 Data Report: Groundwater Monitoring Program, Area 5 Radioactive Waste Management Site (NSTec, 2013a). 
Table 4-3 Investigation Levels and Results from 2012 Groundwater Monitoring

\begin{tabular}{|ccc||}
\hline $\begin{array}{c}\text { Indicator } \\
\text { Parameter }\end{array}$ & $\begin{array}{c}\text { Investigation } \\
\text { Level }\end{array}$ & Results \\
\hline $\mathrm{pH}$ & $<7.6$ or $>9.2$ & 8.24 to 8.39 \\
$\mathrm{SC}$ & $0.440 \mathrm{mmhos} / \mathrm{cm}$ & 0.362 to $0.383 \mathrm{mmhos} / \mathrm{cm}$ \\
TOC & $1 \mathrm{mg} / \mathrm{L}$ & $<0.20$ to $0.35 \mathrm{mg} / \mathrm{L}$ \\
TOX & $50 \mu \mathrm{g} / \mathrm{L}$ & 8.2 to $<20 \mu \mathrm{g} / \mathrm{L}$ \\
Tritium & $2,000 \mathrm{pCi} / \mathrm{L}$ & 1.57 to $6.84 \mathrm{pCi} / \mathrm{L}$ \\
\hline \hline
\end{tabular}

Units are millimhos per centimeter (mmhos/cm), milligrams per liter (mg/L), micrograms per liter $(\mu \mathrm{g} / \mathrm{L})$, and picocuries per liter $(\mathrm{pCi} / \mathrm{L})$.

Groundwater elevations at the pilot wells are measured quarterly using an electronic tape. All groundwater elevation data since the wells were drilled in 1993 are shown in Figure 4-10. The 2012 average depths to groundwater from the top of casing are $235.85 \mathrm{~m}$ (773.78 ft) at UE5PW-1, $256.46 \mathrm{~m}(841.40 \mathrm{ft})$ at UE5PW-2, and $271.56 \mathrm{~m}(890.94 \mathrm{ft})$ at UE5PW-3. The average groundwater elevations are $733.52 \mathrm{~m}(2406.55 \mathrm{ft})$ AMSL at UE5PW-1, $733.67 \mathrm{~m}$ (2407.05 ft) AMSL at UE5PW-2, and $733.67 \mathrm{~m}(2407.05 \mathrm{ft})$ AMSL at UE5PW-3. These data indicate that the water table beneath the Area 5 RWMS is flat, with little or no groundwater flow. Estimated groundwater flow velocity is less than $0.10 \mathrm{~m} / \mathrm{year}(0.33 \mathrm{ft} / \mathrm{year})$ to the south.

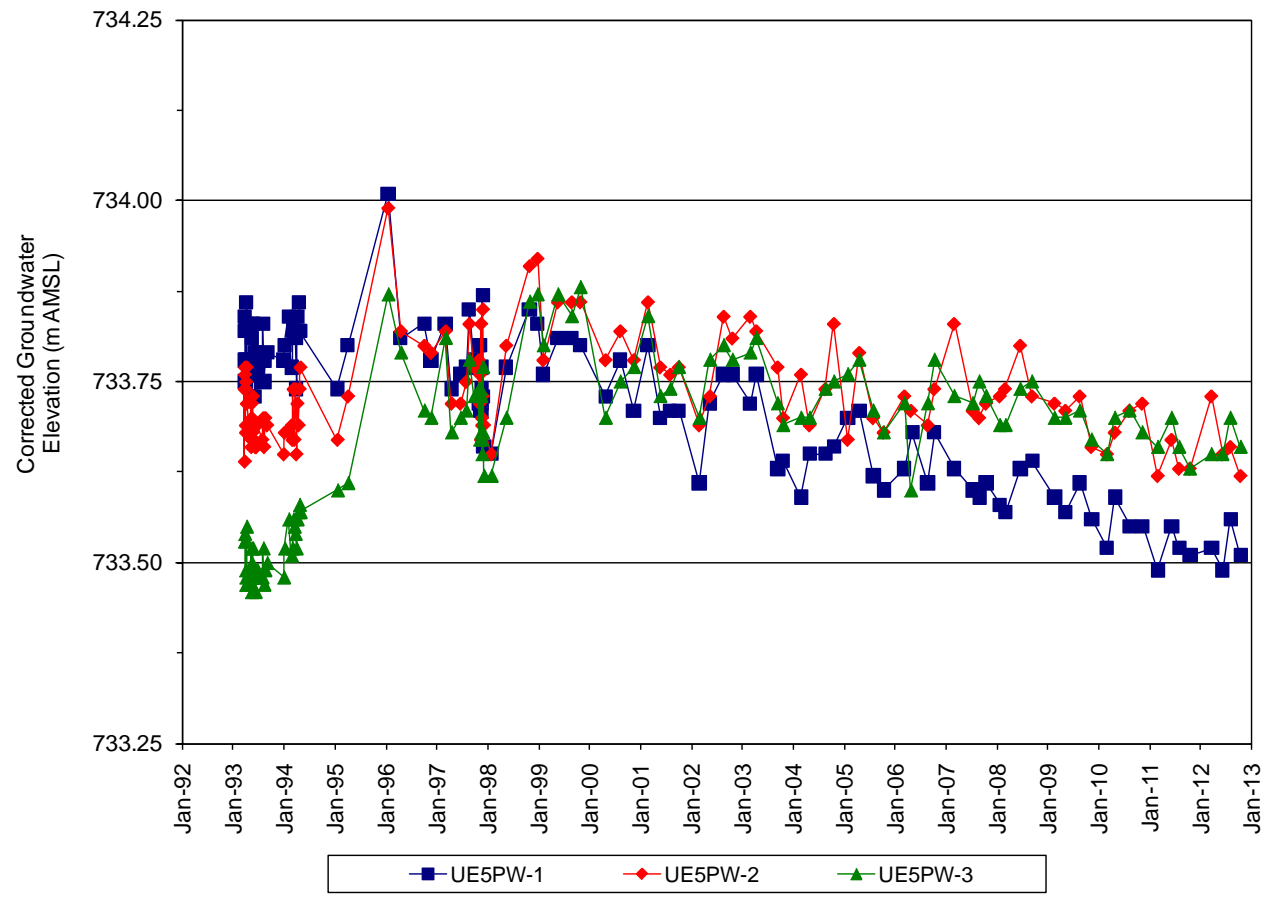

Figure 4-10 Groundwater Elevation at the Area 5 RWMS Pilot Wells 


\subsubsection{Leachate Monitoring at P18}

P18 is a lined, mixed waste cell that was constructed in 2010 and began receiving waste in January 2011. This cell replaced P3 for disposal of MLLW at the Area 5 RWMS after P3 was closed as part of the 92-Acre Area closure. The liner is a RCRA-compliant double liner with a leachate collection system over a geosynthetic clay liner. The footprint of the cell is 1.35 hectares (3.33 acres). The cell floor liner is covered with approximately 75 centimeters (cm) (30 in.) of compacted soil, and the side slope liner is covered with approximately $60 \mathrm{~cm}$ (24 in.) of compacted soil. Limited water storage above the liner, no drainage through the liner, and no plants to remove water by ET causes infiltrated precipitation to drain toward and collect in the cell sump.

Approximately 51,000 liters (13,500 gallons) of leachate has been collected from above the primary liner of P18 between January 2011 and December 2012. This leachate volume is equivalent to approximately $0.4 \mathrm{~cm}$ (0.15 in.) of precipitation over the 1.35-hectare liner area. No leachate has ever been collected between the primary and underlying secondary liner, indicating the primary liner is functioning as designed. Leachate samples were collected when the 3000-gallon collection tank approached its capacity and needed to be drained. Samples were collected from the tank on March 9, 2011; September 28, 2011; August 23, 2012; September 19, 2012; and November 27, 2012. Toxicity Characteristic Leaching Procedure (TCLP) analysis for volatile and semi-volatile organic compounds, pesticides, herbicides, and metals and analysis for polychlorinated biphenyls (PCB) were done to look for evidence of leachate contamination from the waste. TCLP analysis results were compared to regulatory levels in Table 1 of 40 CFR 261.24, and none of the measured results exceeded these levels. All results for PCB were below the detection limit. Based on the TCLP and PCB results, the leachate was pumped from the tank and used for dust control at P18. The leachate samples were also analyzed for tritium, gross alpha activity, and gross beta activity. Tritium activity ranged from not detectable to $612 \mathrm{pCi} / \mathrm{L}$. All tritium results are below the $20,000 \mathrm{pCi} / \mathrm{L}$ EPA maximum contaminant level (MCL) for drinking water. Gross alpha activity ranged from not detectable to $72 \mathrm{pCi} / \mathrm{L}$. Only one gross alpha result from September 19, 2012, exceeded the $15 \mathrm{pCi} / \mathrm{L}$ EPA MCL for gross alpha for drinking water. Gross beta activity ranged from 24 to $38 \mathrm{pCi} / \mathrm{L}$. All gross beta activity results are below the $50 \mathrm{pCi} / \mathrm{L}$ EPA MCL for drinking water.

\subsection{METEOROLOGY MONITORING DATA}

Meteorology monitoring data collected in 2012 include precipitation, air temperature, humidity, wind speed and direction, barometric pressure, and incoming solar radiation. Net solar radiation, soil heat flux, soil temperature, and soil water content are also measured for energy balance based calculations of ET. These are basic meteorological parameters required to quantify the exchange of water and heat between the soil and the atmosphere. These data were collected from two meteorology stations, one located approximately $30 \mathrm{~m} \mathrm{(100} \mathrm{ft)} \mathrm{northwest} \mathrm{of} \mathrm{the} \mathrm{Area} 3$

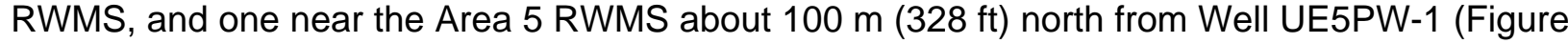
3-1 and Figure 3-2).

\subsubsection{Air Temperature}

Air temperatures at the Area 3 RWMS are slightly cooler than air temperatures at the Area 5 RWMS. The 2012 average recorded temperatures at $3 \mathrm{~m}(10 \mathrm{ft})$ are $14.7^{\circ} \mathrm{C}\left(58.5^{\circ} \mathrm{F}\right)$ at the Area 3 RWMS and $16.9^{\circ} \mathrm{C}\left(62.4^{\circ} \mathrm{F}\right)$ at the Area 5 RWMS. The 2012 maximum and minimum temperatures at $3 \mathrm{~m}(10 \mathrm{ft})$ at the Area $3 \mathrm{RWMS}$ are $41.7^{\circ} \mathrm{C}\left(107.1^{\circ} \mathrm{F}\right)$ on July 11,2012 , and 
$-14.7^{\circ} \mathrm{C}\left(5.5^{\circ} \mathrm{F}\right)$ on January 17,2012 , and at the Area $5 \mathrm{RWMS}$ are $43.9^{\circ} \mathrm{C}\left(111.0^{\circ} \mathrm{F}\right)$ on July 11,2012 , and $-10.4^{\circ} \mathrm{C}\left(13.3^{\circ} \mathrm{F}\right)$ on January 13, 2012 (Figure 4-11).

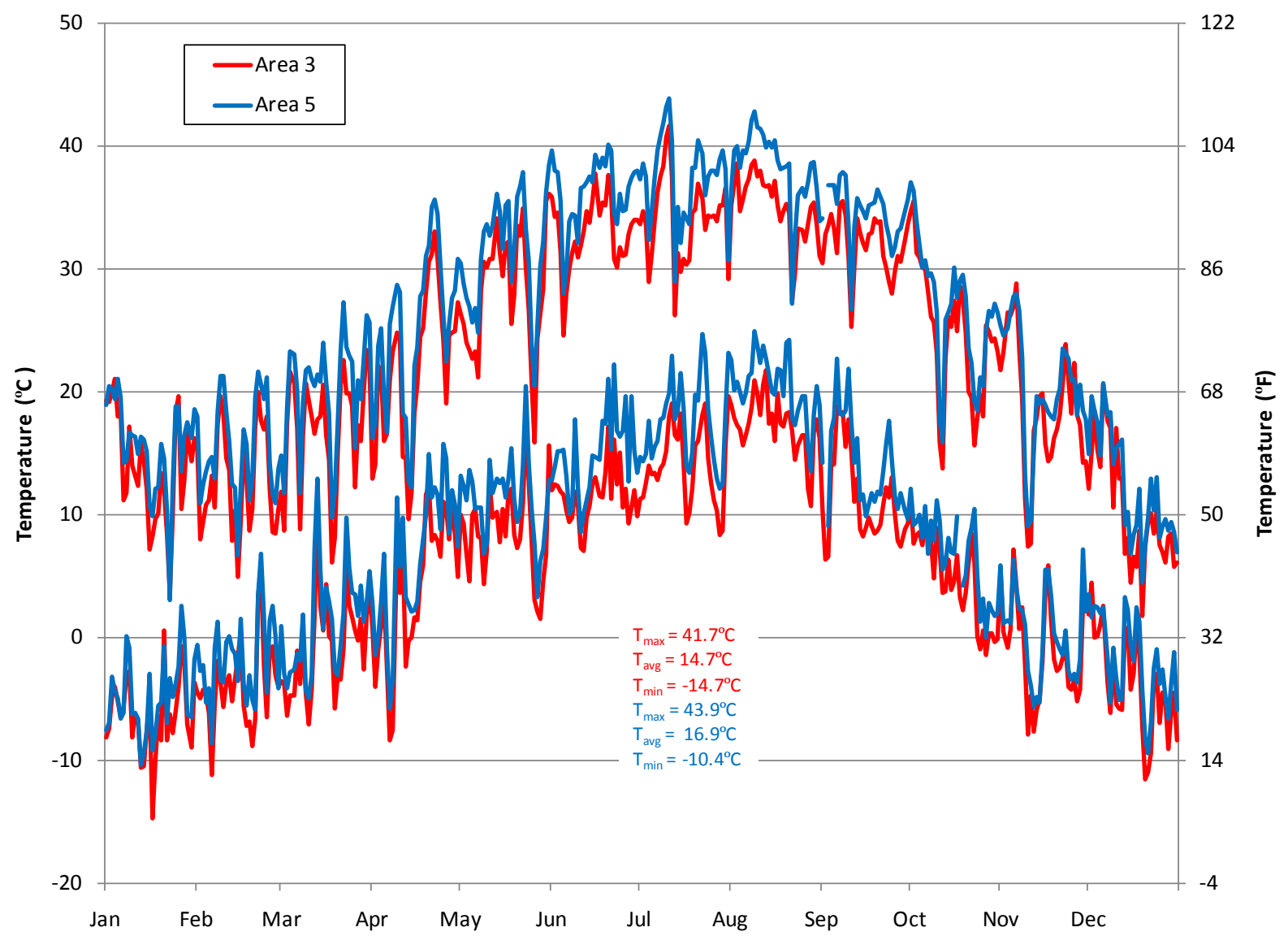

Figure 4-11 Daily Maximum and Minimum $3 \mathrm{~m}$ Temperature at Area 3 and Area 5 RWMS

\subsubsection{Relative Humidity}

Measured relative humidity at the Area 3 RWMS and the Area 5 RWMS is similar. The daily average relative humidity during 2012 at these two sites is 33.0\% for Area 3 and $31.6 \%$ for Area 5 (Figure 4-12). Measured daily average relative humidity ranged from $5.4 \%$ to $85.2 \%$. 


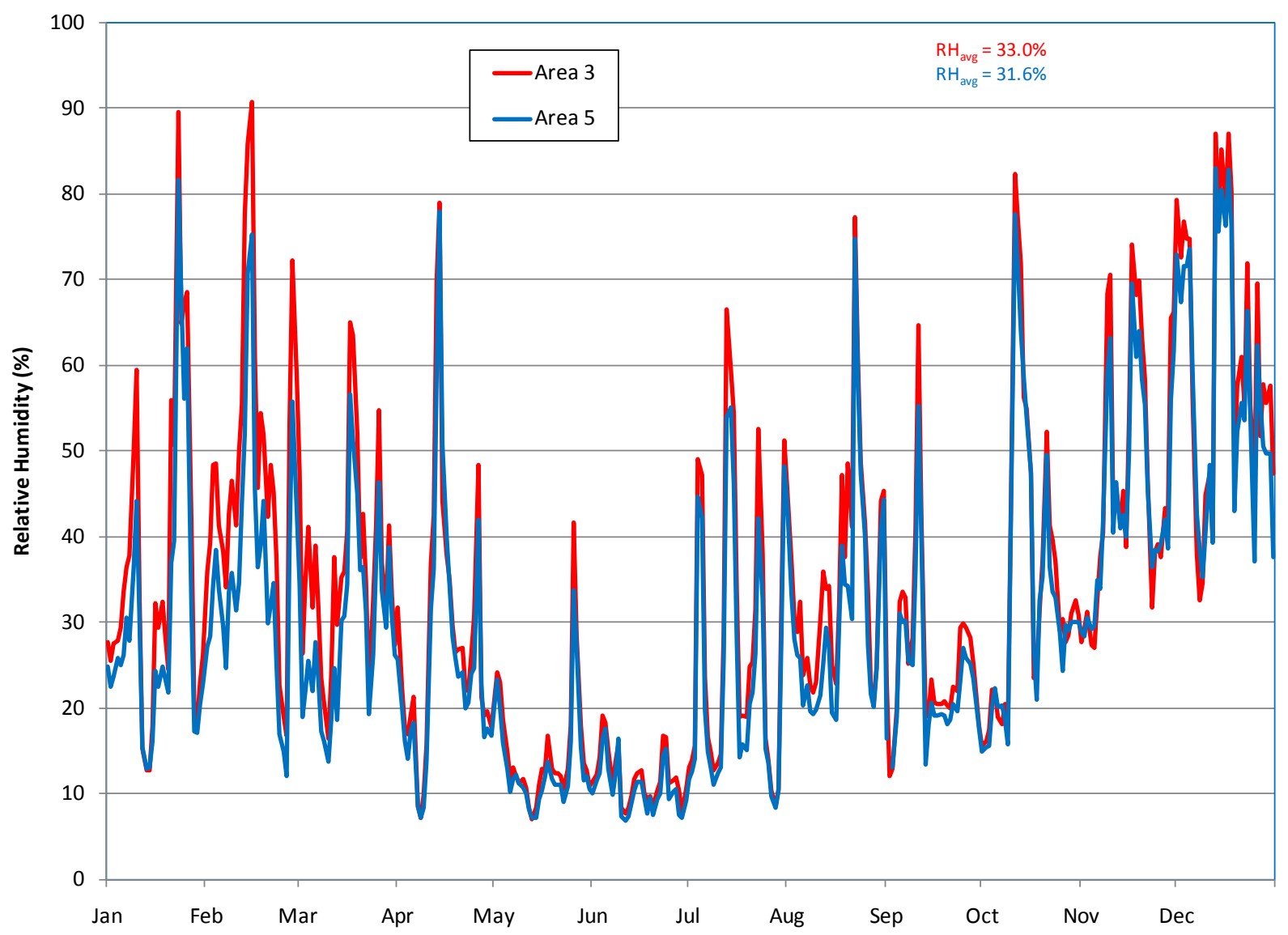

Figure 4-12 Daily Average Relative Humidity at the Area 3 and Area 5 RWMSs

\subsubsection{Barometric Pressure}

Average daily barometric pressure measured at the Area 3 RWMS and the Area 5 RWMS typically show very similar patterns. The pressure transducer used to measure barometric pressure at Area 5 was replaced on March 13, 2012. The replacement transducer did not function properly, so the Area 5 data are only provided from January 1, 2012, through March 12, 2012. The average barometric pressure at the Area 3 RWMS is 87.6 kilopascals $(\mathrm{kPa})$ (12.71 pounds per square inch [PSI]). The difference in barometric pressure readings between the two locations is caused by the $261 \mathrm{~m}$ (856 ft) difference in elevation. 


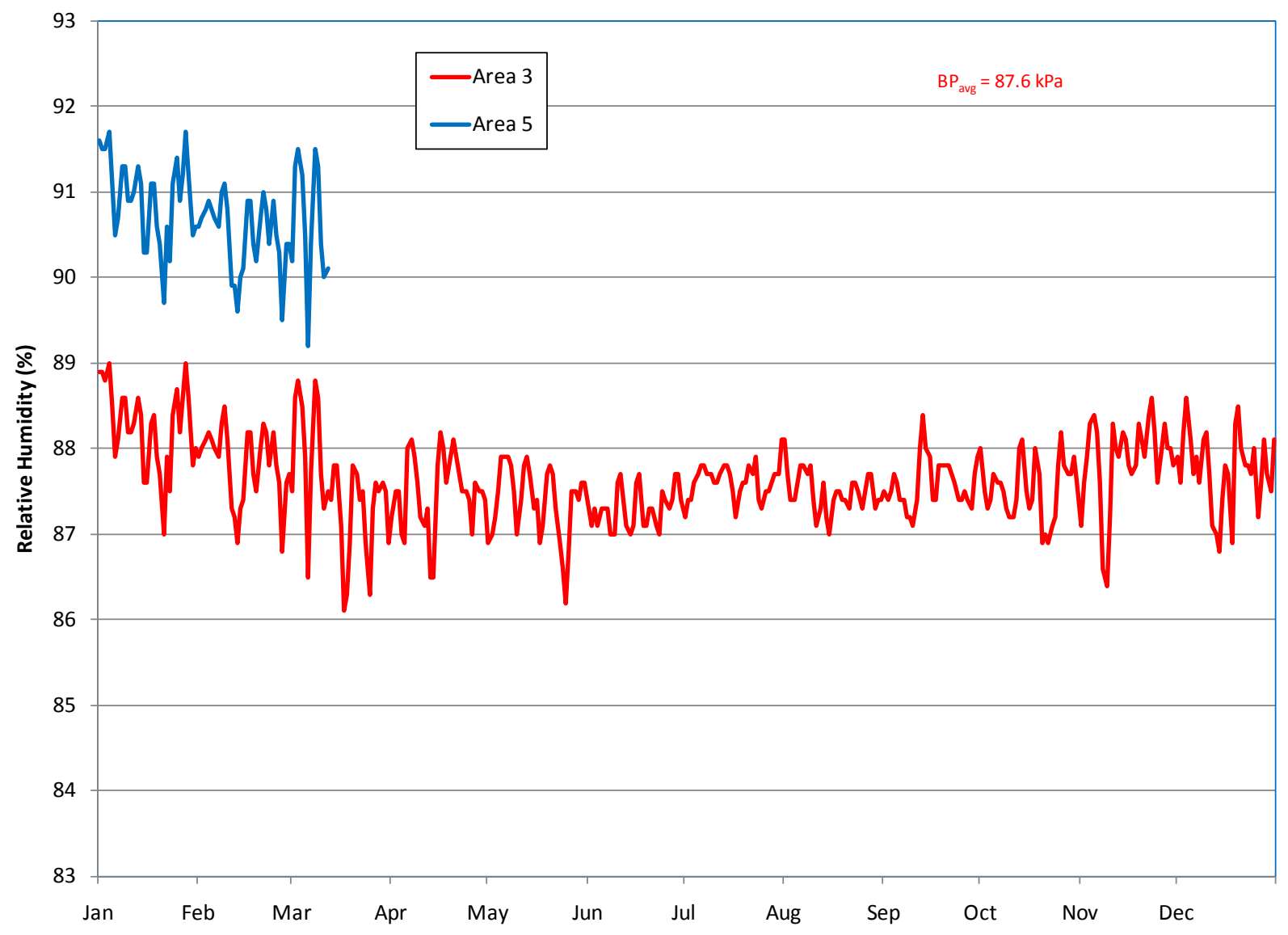

Figure 4-13 Average Barometric Pressure at the Area 3 and Area 5 RWMSs

\subsubsection{Wind Speed and Wind Direction}

The average wind speed is slightly higher at the Area 3 RWMS than at the Area 5 RWMS.

During 2012, the average daily wind speed at the Area 3 RWMS was $3.1 \mathrm{~m} / \mathrm{s}(6.9 \mathrm{mph})$, and the maximum gust was $19.5 \mathrm{~m} / \mathrm{s}$ (43.6 mph) on May 25. During 2012, the average daily wind speed at the Area 5 RWMS was $2.7 \mathrm{~m} / \mathrm{s}$ (6.0 mph), and the maximum gust was $24.9 \mathrm{~m} / \mathrm{s}(55.7 \mathrm{mph})$ on March 6. Daily maximum and average wind speeds are in Figure 4-14 and Figure 4-15.

Wind rose diagrams illustrate wind direction and wind speed distribution in each direction using hourly wind data measured at a height of $3 \mathrm{~m} \mathrm{AGL}$. Generally, more wind comes from the north and higher wind speeds come from the south. Wind roses from the Area 3 and Area 5 RWMSs are presented in Figure 4-16 and Figure 4-17, respectively. The 1-year wind roses presented here are very similar to the multiple-year wind roses. 


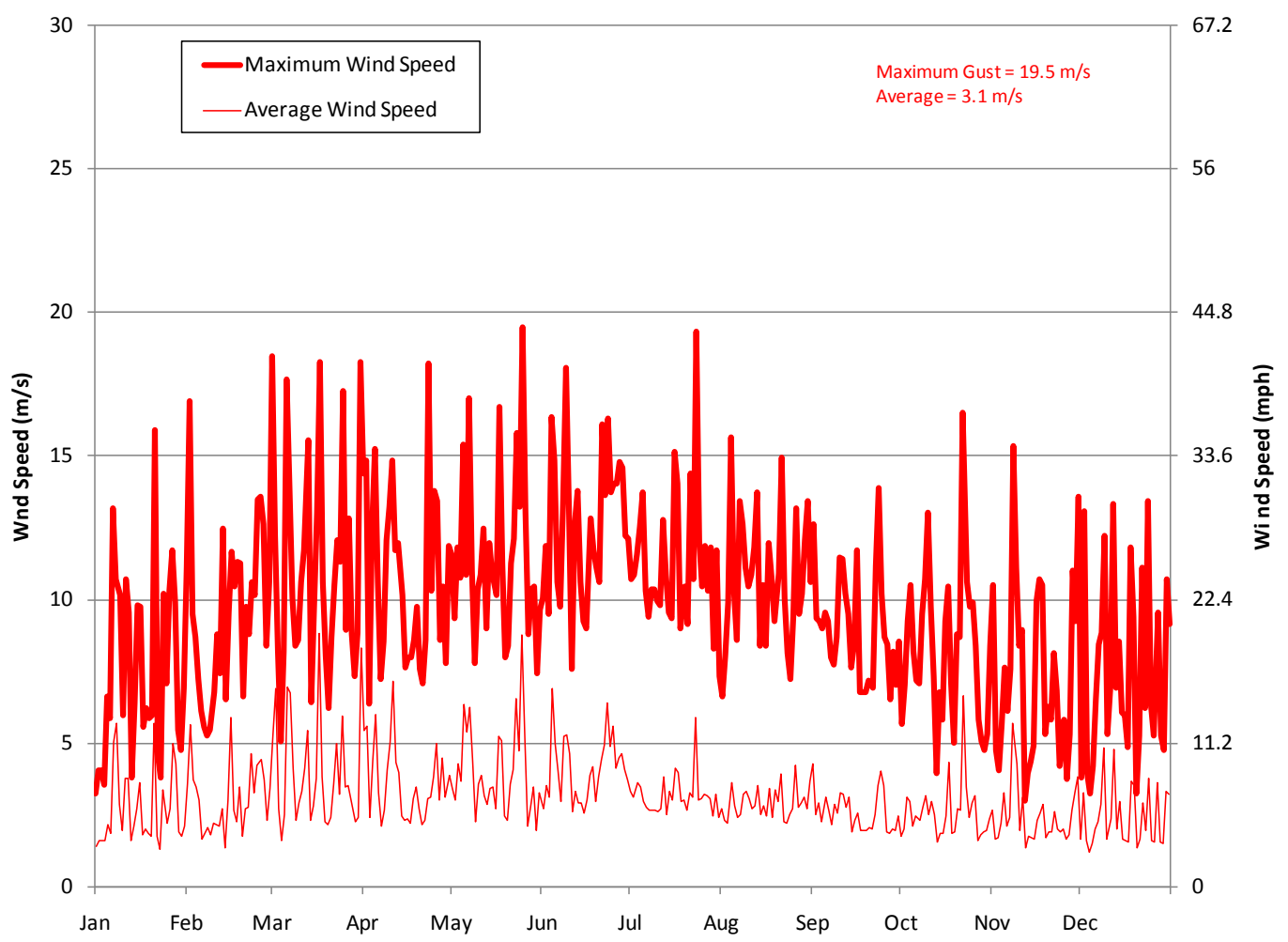

Figure 4-14 Daily $3 \mathrm{~m}$ Wind Speed at the Area 3 RWMS

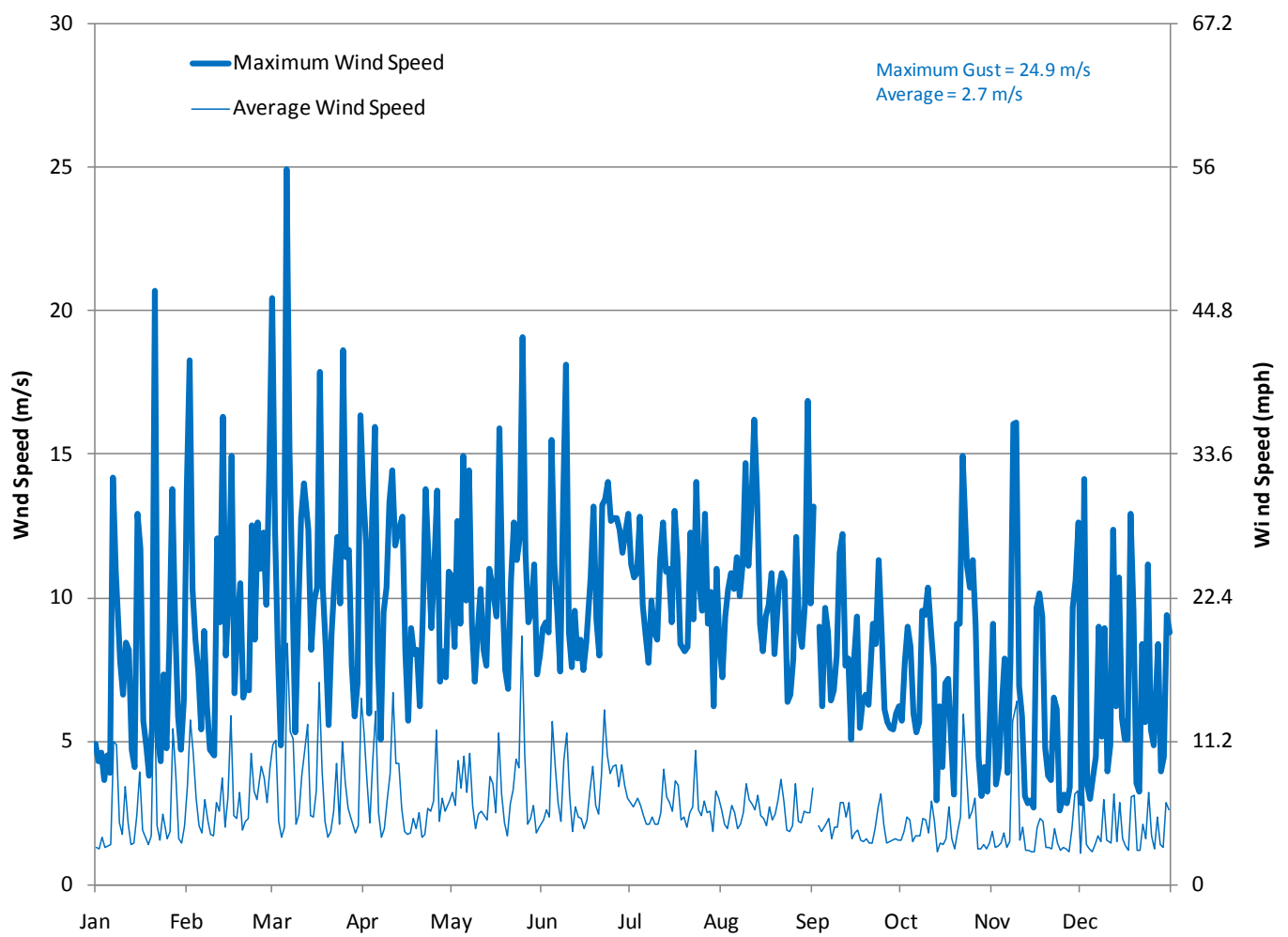

Figure 4-15 Daily $3 \mathrm{~m}$ Wind Speed at the Area 5 RWMS 


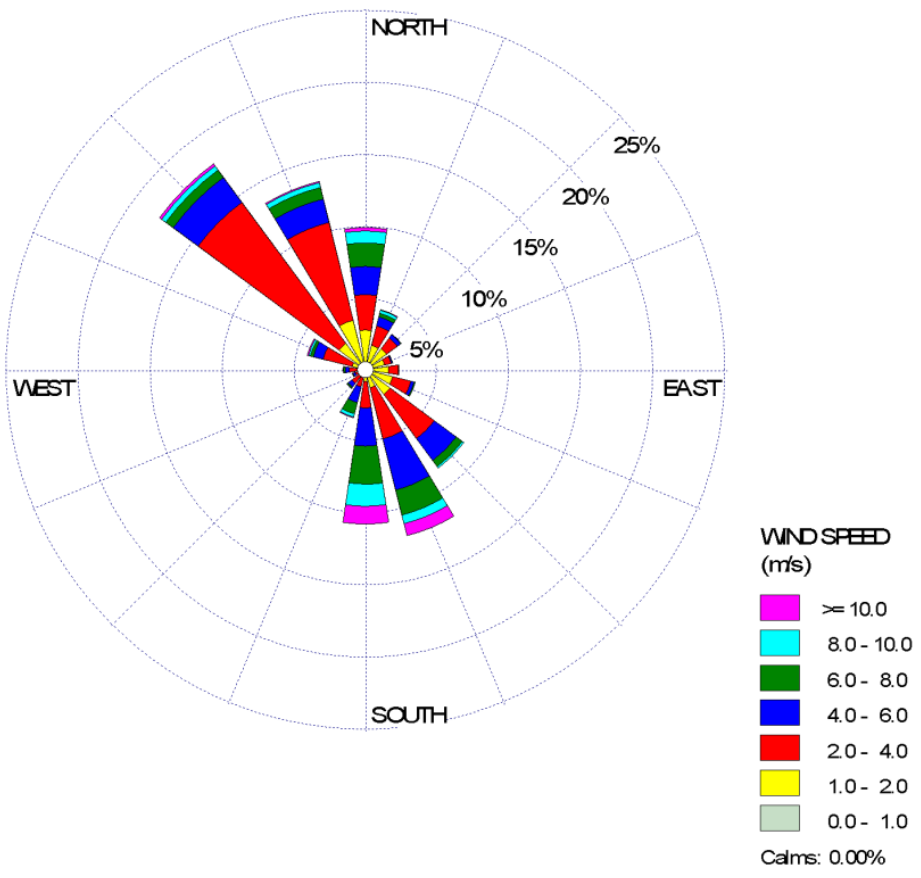

Figure 4-16 Wind Rose Diagram for the Area 3 RWMS

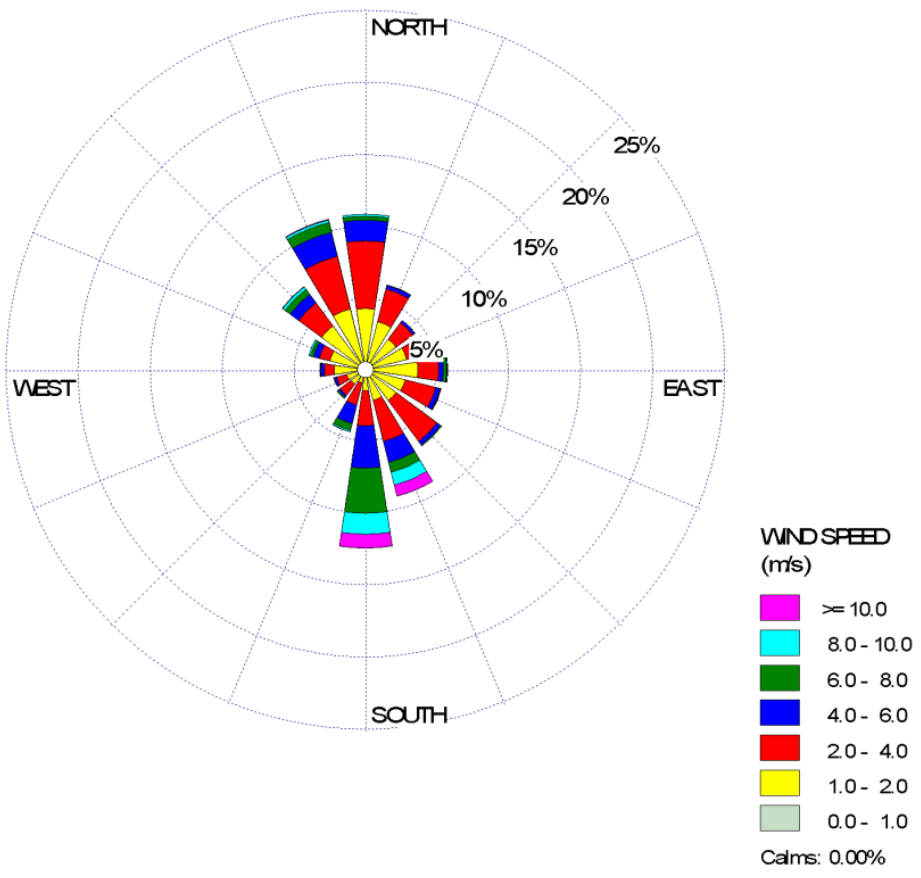

Figure 4-17 Wind Rose Diagram for the Area 5 RWMS 


\subsubsection{Precipitation}

Rainfall at the Area 3 RWMS in 2012 was 12\% below average, totaling $133.9 \mathrm{~mm}$ (5.27 in.). The average annual precipitation measured at the Area 3 RWMS from 1996 through 2012 is $153.0 \mathrm{~mm}$ (6.02 in.). The maximum daily rainfall at the Area 3 RWMS during 2012 was $34.6 \mathrm{~mm}$ (1.36 in.) on October 11. Precipitation was measured on 36 days during 2012 at the Area 3 RWMS (Figure 4-18).

Rainfall at the Area 5 RWMS in 2012 was $11 \%$ below average, totaling $137.6 \mathrm{~mm}$ (5.42 in.). The average annual precipitation measured at the Area 5 RWMS from 1995 through 2012 is $122.4 \mathrm{~mm}$ (4.82 in.). The maximum daily rainfall at the Area 5 RWMS during 2012 was $29.9 \mathrm{~mm}$ (1.18 in.) on October 11. Precipitation was measured on 32 days during 2012 at the Area 5 RWMS (Figure 4-19).

Historical precipitation data recorded at BJY (located about $3 \mathrm{~km}$ [2 mi] northwest of the Area 3 RWMS) and at the Area 3 RWMS are in Figure 4-20. The BJY station is a Meteorological Data Acquisition (MEDA) station operated by ARL/SORD. The 52-year average annual precipitation at BJY from 1961 to 2012 is $160.8 \mathrm{~mm}$ (6.33 in.). Historical precipitation data recorded at the Well 5B station (located about $5.5 \mathrm{~km}$ [3.4 mi] south of the Area 5 RWMS) and at the Area 5 RWMS are provided in Figure 4-21. The Well 5B station is also an ARL/SORD MEDA station. The 50-year average annual precipitation at Well 5B from 1963 to 2012 is $122.4 \mathrm{~mm}$ (4.82 in.).

\subsubsection{Reference Evapotranspiration}

The calculated $2012 \mathrm{ET}_{\text {ref }}$ at the Area 3 RWMS is 1,657 mm (65.2 in.) and at the Area 5 RWMS is $1,608 \mathrm{~mm}$ (63.3 in.). $\mathrm{ET}_{\text {ref }}$ is the rate that readily available soil water is vaporized from a uniform surface of dense, actively growing vegetation. Crop coefficients are used to convert $E T_{\text {ref }}$ to potential evapotranspiration rates (Allen et al., 2005). $E T_{\text {ref }}$ is calculated using a modified version of the radiation-based equation of Doorenbos and Pruitt (1977). The equation calculates $\mathrm{ET}_{\text {ref }}$ from hourly measurements of solar radiation, air temperature, relative humidity, wind speed, and barometric pressure. This method provides results similar to the Penman Equation that was previously used for the data reports through 2001 (Campbell, 1977). The Doorenbos and Pruitt equation reduces data input requirements because no net radiation data are used. The ratio of $\mathrm{ET}_{\text {ref }}$ to precipitation in 2012 at the Area $3 \mathrm{RWMS}$ is 12.4, and the ratio $\mathrm{ET}_{\text {ref }}$ to precipitation in 2012 at the Area 5 RWMS is 11.7. 


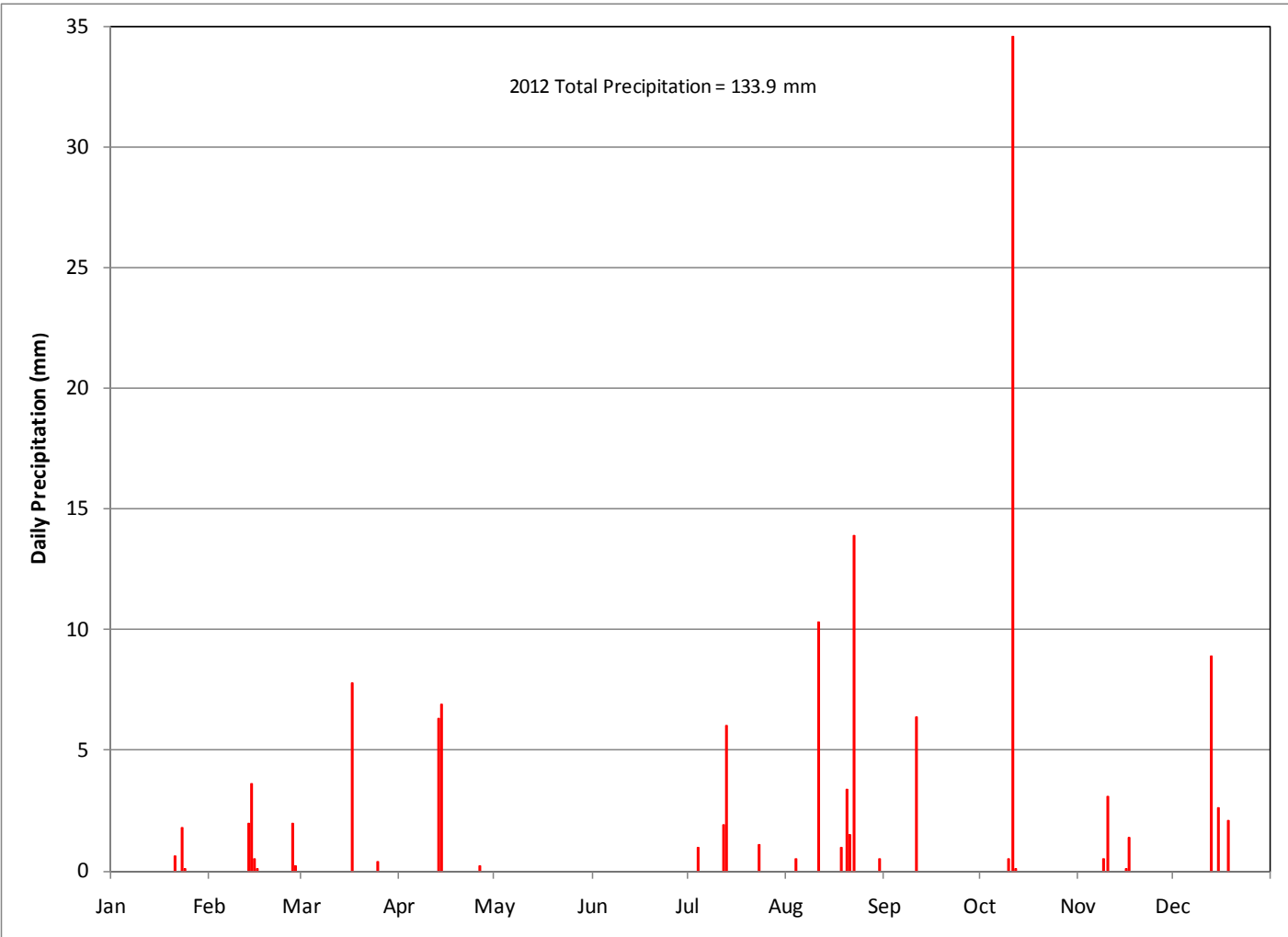

Figure 4-18 Daily Precipitation at the Area 3 RWMS

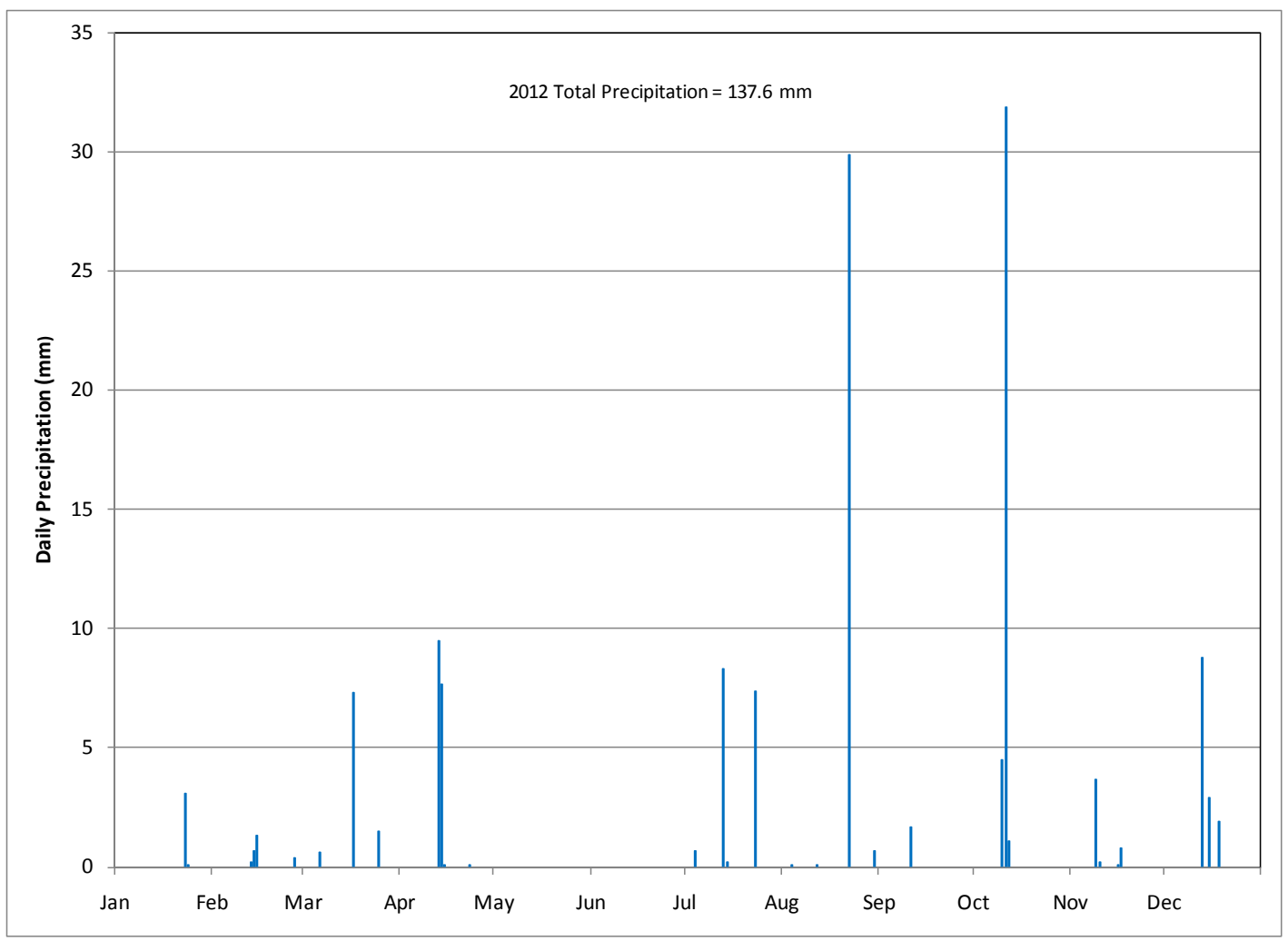

Figure 4-19 Daily Precipitation at the Area 5 RWMS 


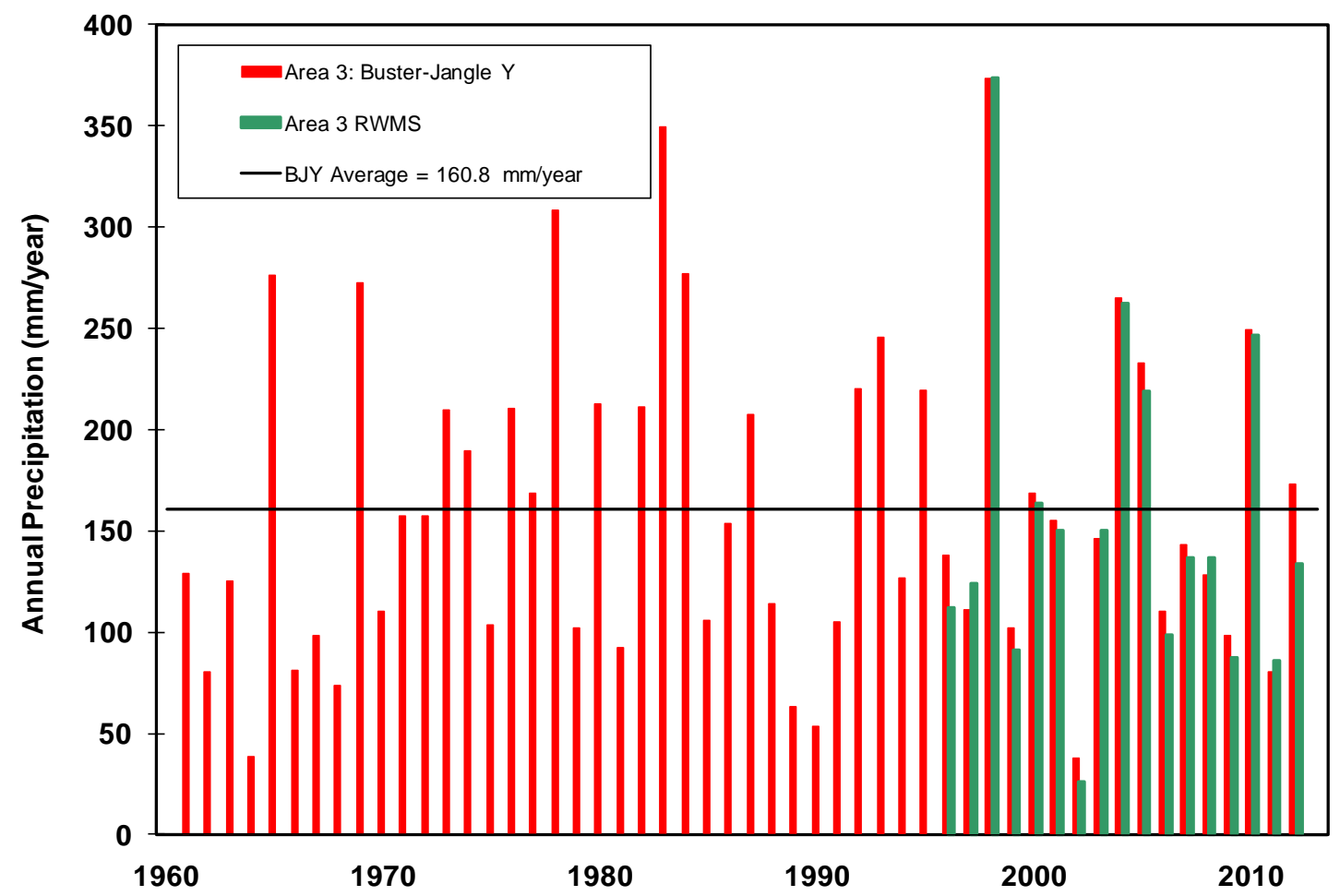

Figure 4-20 Historical Precipitation Record for the Buster-Jangle $Y$ and the Area 3 RWMS

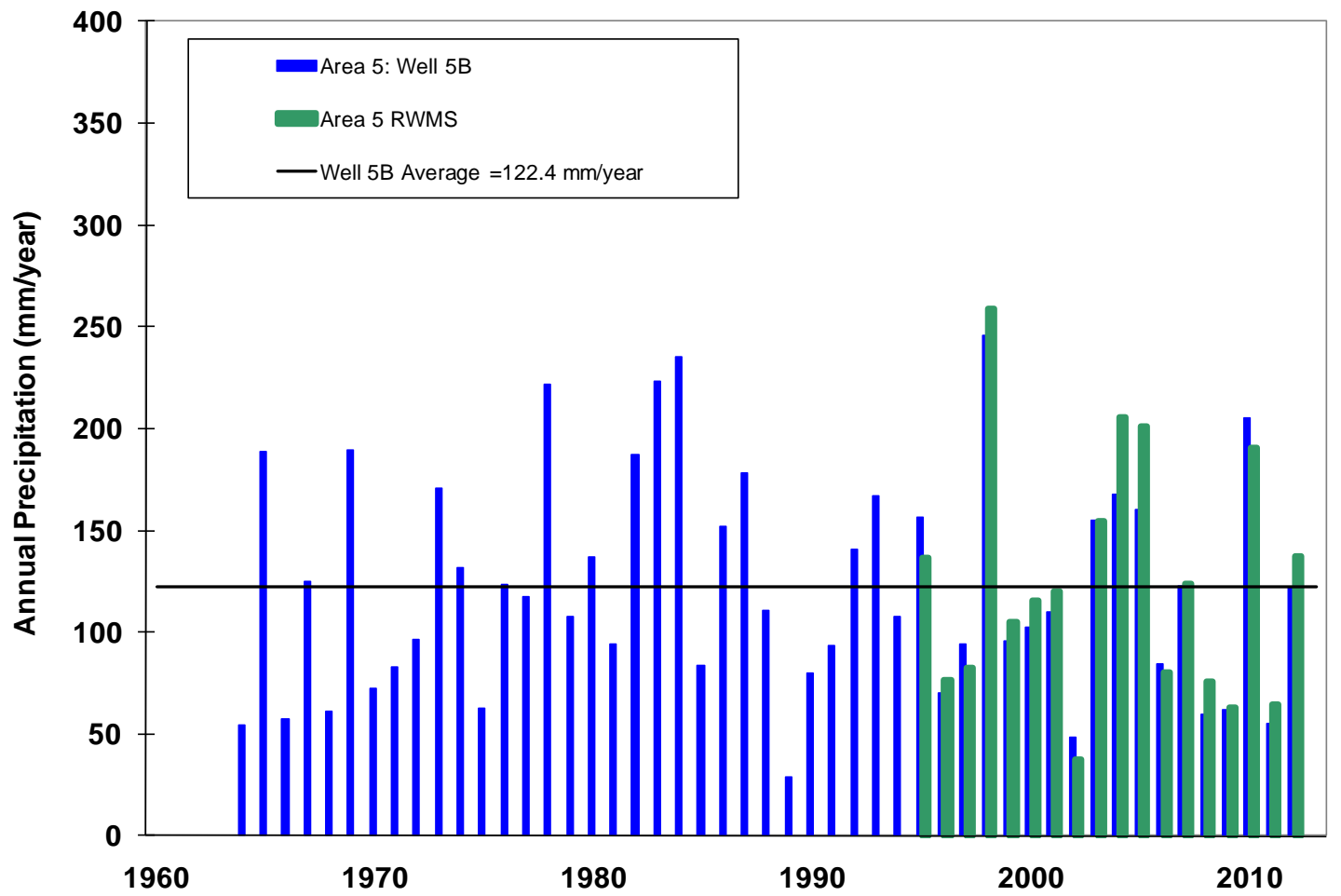

Figure 4-21 Historical Precipitation Record for the Well 5B and Area 5 RWMS 


\subsection{VADOSE ZONE MONITORING DATA}

\subsubsection{Monitoring Strategy}

Vadose zone monitoring is conducted at the Area 3 and Area 5 RWMSs to demonstrate compliance with DOE O 435.1 and confirm the assumptions in the PA for each RWMS (e.g., hydrologic conceptual models, including soil water contents, flux rates and directions, and volatile radionuclide releases). The vadose zone monitoring is also performed to detect changing trends in performance, provide added assurance to PA conclusions regarding facility performance, evaluate the performance of the operational monolayer waste covers, and confirm the PA performance objective of protecting groundwater resources.

The design of the current vadose zone monitoring program at the RWMSs is based on an understanding of the vadose zone system acquired through extensive characterization studies (BN, 1998; 2005a; 2005b; Blout et al., 1995; Reynolds Electrical \& Engineering Co., Inc., 1993a; 1993b; Shott et al., 1997; 1998; Tyler et al., 1996) and modeling studies (Levitt et al., 1999; Desotell et al., 2006; 2007). The objectives of the vadose zone monitoring program are accomplished, in part, by measuring water balances at each RWMS. Water balance studies involve using meteorology data to calculate $\mathrm{ET}_{\text {ref }}$ values (the driving force of upward flow), directly measuring ET and bare-soil E at the RWMS lysimeter facilities, and measuring soil water content and soil water potential in waste cell covers and floors using automated waste cover monitoring systems.

\subsubsection{Area 5 Weighing Lysimeter Facility}

The Area 5 Weighing Lysimeter Facility consists of two precision weighing lysimeters located about $400 \mathrm{~m}(1,312 \mathrm{ft})$ southwest of the Area 5 RWMS (see Figure 2-1). Each lysimeter is an open-top steel box, measuring $2 \mathrm{~m}$ wide by $4 \mathrm{~m}$ long by $2 \mathrm{~m}$ deep $(6.6 \mathrm{ft}$ wide by $13 \mathrm{ft}$ long by $6.6 \mathrm{ft}$ deep), filled with soil and mounted on a sensitive scale. Weight changes of each lysimeter are continuously monitored using an electronic load cell. Each load cell can measure approximately $0.1 \mathrm{~mm}(0.004 \mathrm{in}$.) of precipitation or ET. One lysimeter is vegetated with the native plant species Larrea tridentata (creosote bush), Lycium andersonii (Anderson's wolfberry), and Schismus arabicus (Arabian schismus) at the approximate density of the surrounding desert. The other lysimeter is kept bare to simulate the bare operational waste covers at the Area 5 RWMS. The lysimeters have provided surface water balance data at the Area 5 RWMS since March 1994.

The weighing lysimeter data represent a simplified water balance: the change in soil water storage is equal to precipitation minus $\mathrm{E}$ (on bare lysimeters) or ET (on vegetated lysimeters). The water balance is simplified because no drainage can occur through the solid bottoms of the lysimeters and because a $2.5 \mathrm{~cm}$ (1 in.) lip around the edge of the lysimeters prevents run-on and runoff. Total soil water storage for the period of March 30, 1994, through December 31, 2012, is provided in Figure 4-22. 


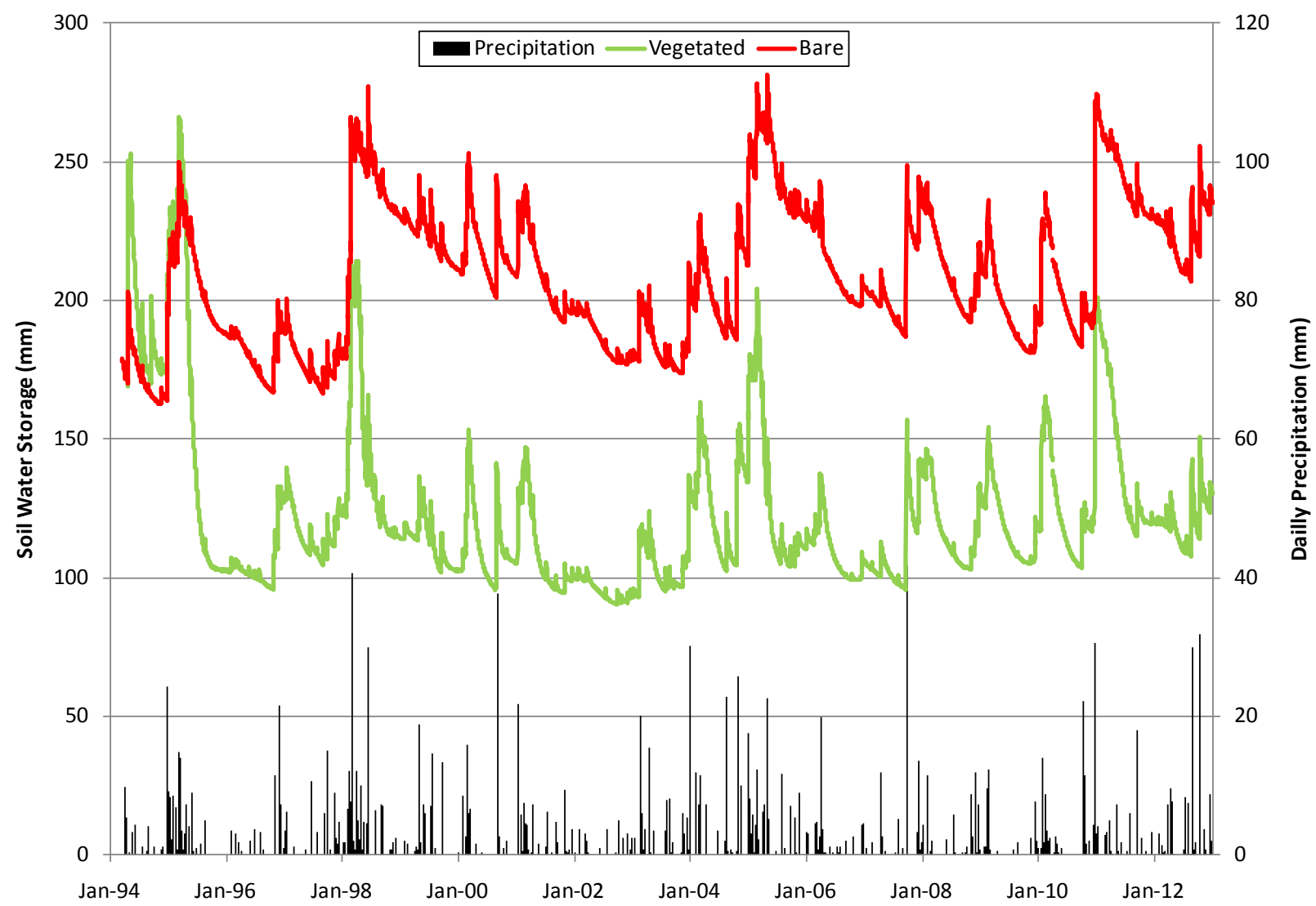

Figure 4-22 Weighing Lysimeter Data from March 1994 to December 2012

The vegetated lysimeter is considerably drier than the bare-soil lysimeter despite the small number of plants on the vegetated lysimeter (12.5\% plant cover). Cover was measured for both the vegetated and bare-soil weighing lysimeters on May 23, 2012. The results are summarized in Table 4-4.

Table 4-4 Weighing Lysimeters Percent Cover

\begin{tabular}{||ccccc||}
\hline Lysimeter & $\begin{array}{c}\text { Plant Cover } \\
\text { (percent) }\end{array}$ & $\begin{array}{c}\text { Bare } \\
\text { (percent) }\end{array}$ & $\begin{array}{c}\text { Gravel } \\
\text { (percent) }\end{array}$ & $\begin{array}{c}\text { Litter } \\
\text { (percent) }\end{array}$ \\
\hline Vegetated & 12.5 & 15.0 & 57.5 & 15.0 \\
Bare Soil & 0.0 & 15.0 & 85.0 & 0.0 \\
\hline
\end{tabular}


The average soil water storage depth in the vegetated lysimeter from January 1, 1996, through December 31, 2012, is $118 \mathrm{~mm}$ (4.6 in.). This is equivalent to average volumetric water content (VWC) of 5.9\%. For the same period, the average soil water storage depth in the bare lysimeter is $210 \mathrm{~mm}$ (8.3 in.), which is equivalent to an average VWC of 10.5\%. During 2012, the average soil water storage depth in the vegetated lysimeter was $121 \mathrm{~mm}$ (4.8 in.), and the average water storage depth in the bare lysimeter was $224 \mathrm{~mm}$ (8.8 in.).

Following high rainfall periods in the winter, soil water storage decreases in the vegetated lysimeter due to ET from rapid plant growth in the spring. As the vegetated lysimeter dries out, plant growth and ET slow. Eventually E from the bare lysimeter exceeds ET from the vegetated lysimeter in the summer due to the higher water content in the bare lysimeter.

No water has ever accumulated at the bottom of the vegetated lysimeter. Heavy precipitation during the late fall and winter combined with low $\mathrm{E}$ rates and higher initial water contents may result in water accumulation at the bottom of the bare lysimeter. A suction of $-8.0 \mathrm{kPa}(-1.2 \mathrm{PSI})$ was applied to the porous suction candles on the bottom of the bare lysimeter from May 5, 2008, to June 19, 2008; from March 2, 2009, to May 12, 2009; and from February 3, 2010, to April 27, 2010. No water effluent was collected from the suction candles during these periods. Long-term numerical simulations (30 years) using a unit gradient bottom boundary estimate the amount of drainage that would have occurred if water could drain from the lysimeters. These simulations indicate an average of $1.0 \mathrm{~cm}(0.4 \mathrm{in}$.) per year of water reaches the bottom of the bare lysimeter, and essentially no water reaches the bottom of the vegetated lysimeter (Desotell et al., 2006).

During 2012, E from the bare lysimeter was $127.0 \mathrm{~mm}$ (5.0 in.) and ET from the vegetated lysimeter was $122.6 \mathrm{~mm}$ (4.8 in.). Water contents in both lysimeters slightly increased during 2012 because both $\mathrm{E}$ and $\mathrm{ET}$ were less than the $137.6 \mathrm{~mm}$ (5.4 in.) of precipitation.

In the beginning of 2012, water storage in the bare lysimeter was higher than normal due to the $89.2 \mathrm{~mm}$ (3.5 in.) of precipitation in December 2010. Most of this moisture was removed from the vegetated lysimeter by ET during 2011 (Figure 4-22). During 2012, E from the bare lysimeter was greater than ET from the vegetated lysimeter during January through May, August, and December. ET increased in April as plants began to grow. ET was greater than E during June, July, and September through November due to precipitation and increased plant growth in the late summer and fall (Figure 4-24).

Monthly precipitation was less than ET in February, May, June, September, and November and, monthly precipitation was less than E in March, July, August, October, and December (Figure 4-24). 


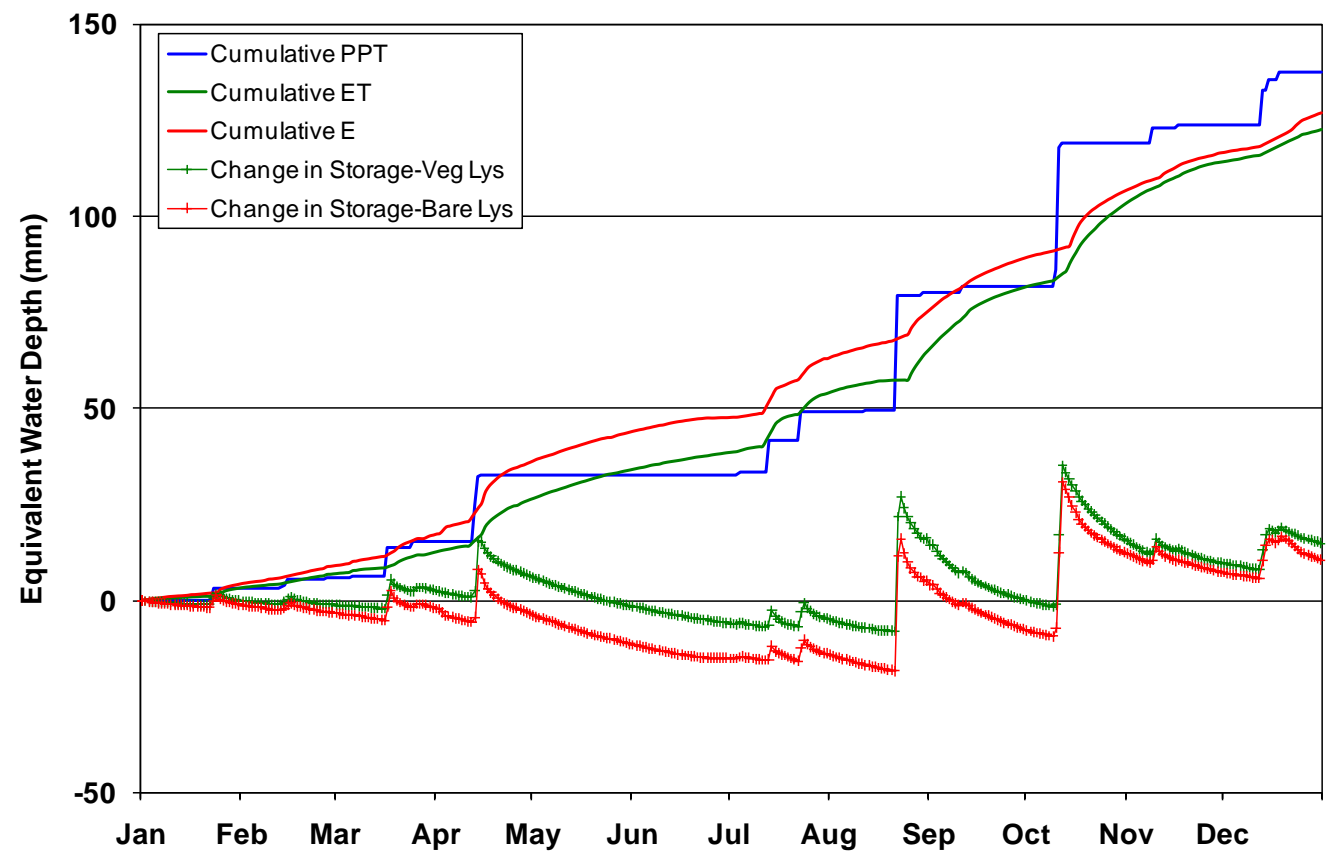

Figure 4-23 Precipitation, ET, E, and Storage for the Weighing Lysimeters during 2012

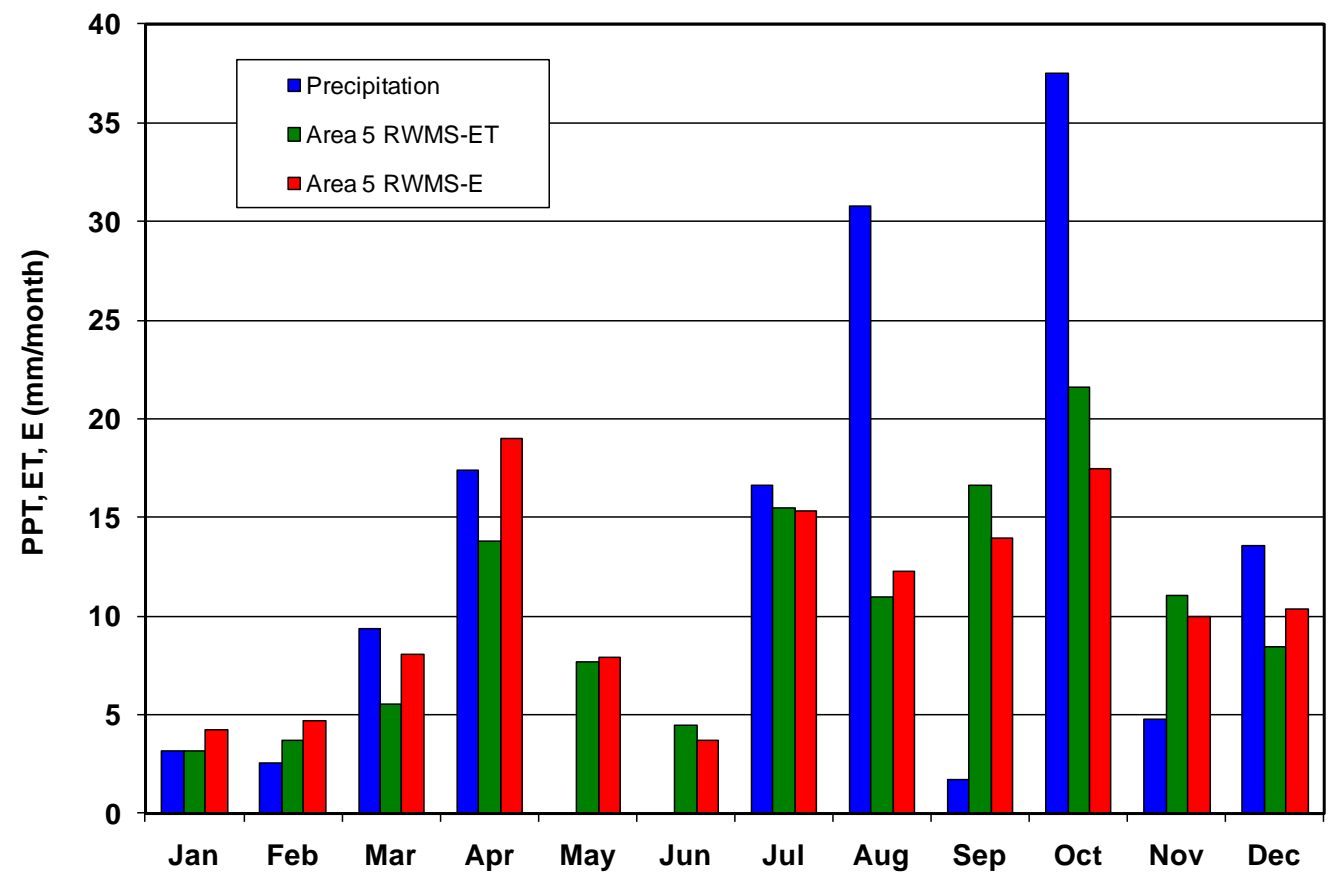

Figure 4-24 Monthly Precipitation, E, and ET during 2012 


\subsubsection{Automated Waste Cover Monitoring System}

Automated vadose monitoring on the operational covers at the Area 5 RWMS was temporarily discontinued during construction of the 92-Acre Area ET cover during 2011. New vadose zone moisture sensors were installed in the final ET cover during October 2011 and monitoring was continued.

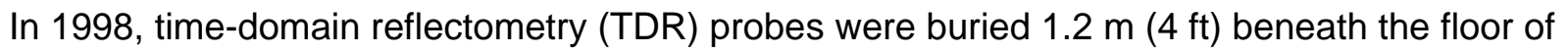
open Pit 5 at the Area 5 RWMS. The four probes are adjacent to the Pit $5 \mathrm{~N}$ and Pit $5 \mathrm{~S}$ monitoring locations with one probe buried near the Pit 5 center line and one probe near the

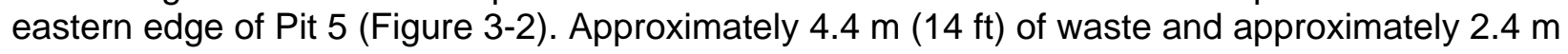
$(8 \mathrm{ft})$ of cover were placed above these probes during disposal. The depth of these probes is

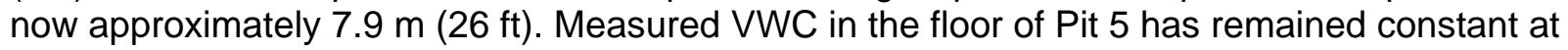
approximately 10\% since measurements began in early 1999 (Figure 4-25). The constant

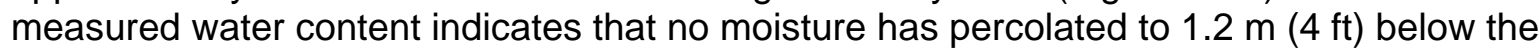
waste. The missing data in 2011 is during the construction of the final cover. The original TDR probes were used after the final cover was completed, but the data appear slightly more variable. This variability may be related to construction of the cover or damage to the probes during construction.

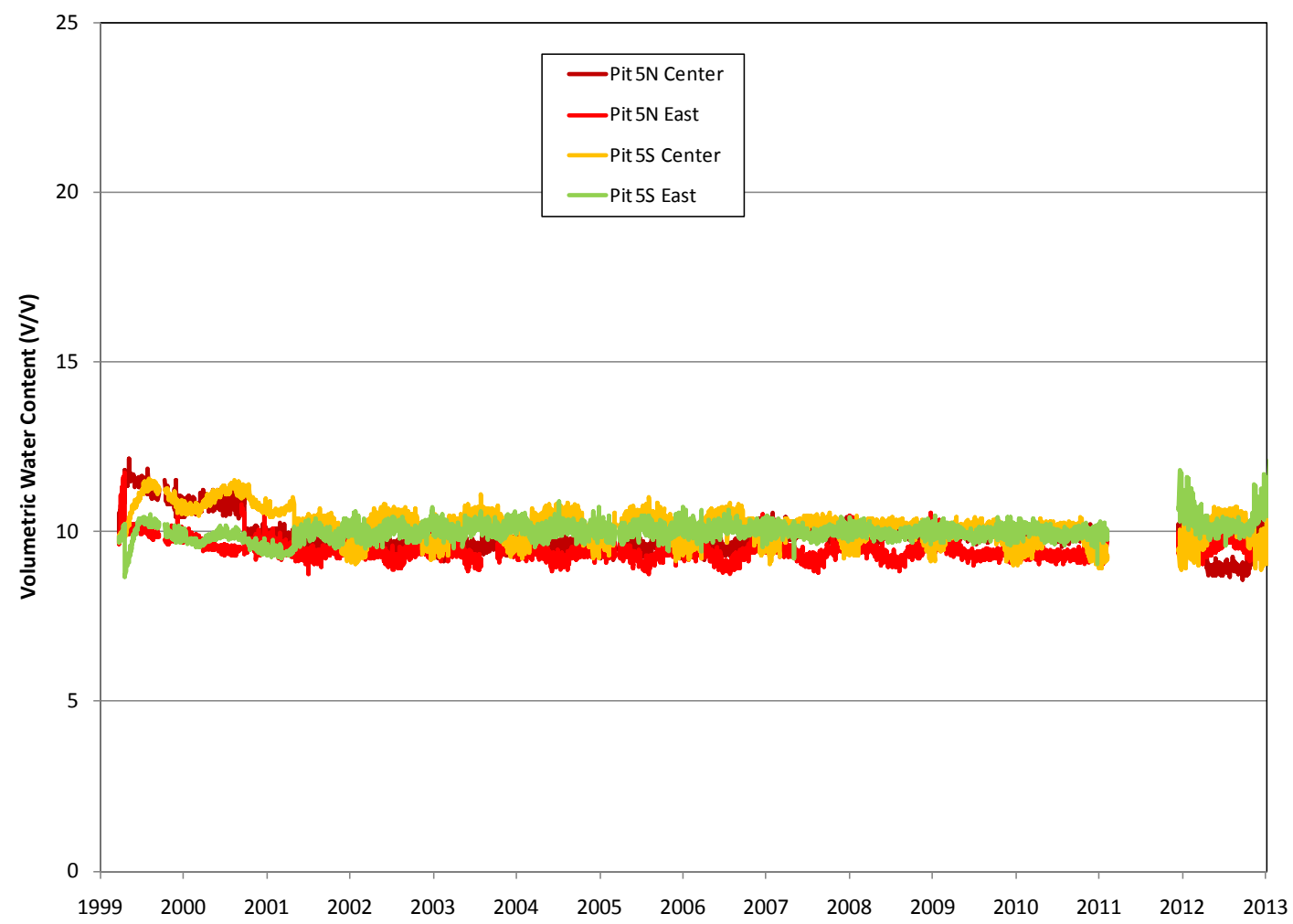

Figure 4-25 Soil Water Content in the Pit 5 Floor

TDR probes were installed in the final cover of the 92 Acre Area after cover construction was completed. Moisture monitoring began at Pit 1, Pit 3W, Pit 5N, and Pit 5S by December 2011 (Figure 3-2). Eight vertically arranged TDR probes were installed at each of the four locations at depths ranging from 15 to $180 \mathrm{~cm}(0.5$ to $6 \mathrm{ft})$. The measured VWC profiles are similar at the 
four locations. Measured VWC values for Pit 5S are shown in Figure 4-26. Initially, water applied to the cover during construction resulted in a uniform VWC distribution between $8 \%$ and $10 \%$. ET from plant growth during the spring and early summer decreased the measured water contents even though $10.9 \mathrm{~cm}$ (4.3 in.) of supplemental irrigation was applied to the cover to help establish vegetation. Precipitation in April, August, October, and December wetted the soil to approximately $30 \mathrm{~cm}$ (12 in.).

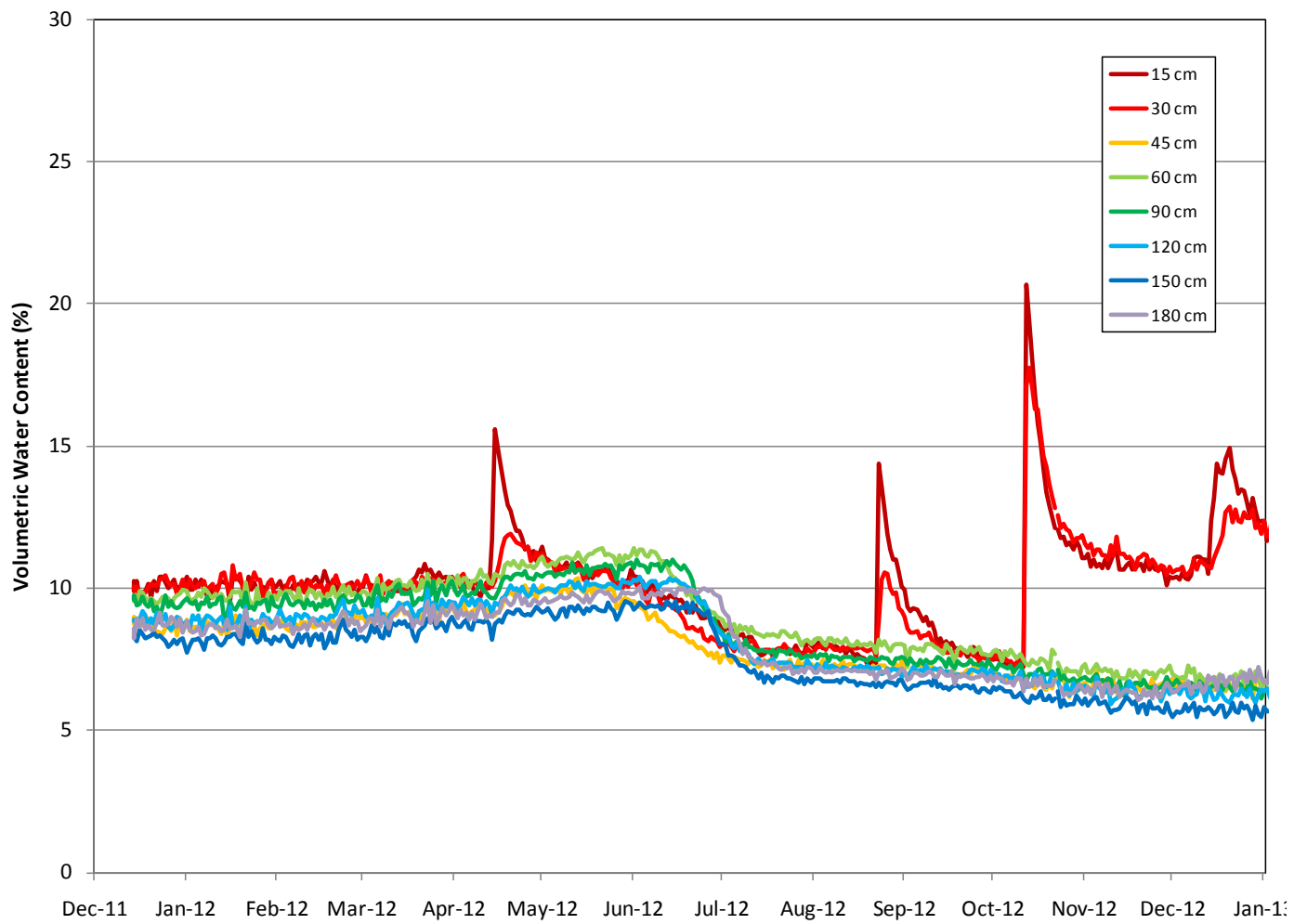

Figure 4-26 Water Content in the 92 Acre Area Cover at Pit 5S

Four strontium-90 $\left({ }^{90} \mathrm{Sr}\right)$ radioisotope thermoelectric generators (RTGs) were disposed at Cell P5 on September 27, 2007. The power output of these four RTGs is approximately 450 watts. Area 5 RWMS disposal requirements are that RTG surface temperatures remain below $300^{\circ} \mathrm{C}$ $\left(572^{\circ} \mathrm{F}\right)$, soil temperatures within $2 \mathrm{~m}(6.6 \mathrm{ft})$ of the surface remain less than $100^{\circ} \mathrm{C}\left(212^{\circ} \mathrm{F}\right)$, and temperatures in LLW adjacent to the RTGs are below $38^{\circ} \mathrm{C}\left(100^{\circ} \mathrm{F}\right)$. Platinum resistance temperature detectors (RTDs) were installed to measure vertical and horizontal temperature profiles around an RTG. RTDs in the vertical profile were placed directly on top of an RTG to

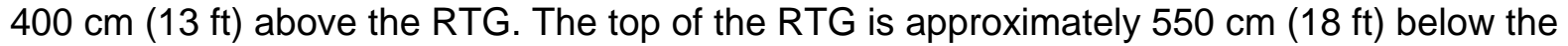
soil surface. RTDs in the horizontal profile were placed on the side of the same RTG to $400 \mathrm{~cm}$ $(13 \mathrm{ft})$ away from the side of the RTG. The RTGs in the horizontal are approximately $550 \mathrm{~cm}$ (18 ft) deep. Figure 4-27 provides the measurements from the vertical temperature profile above the RTG. Locations are given as the distance above the RTG followed by the depth from the soil surface in parentheses. Temperatures at the top of the RTD and approximately $550 \mathrm{~cm}(18 \mathrm{ft})$ below the ground surface were near $110^{\circ} \mathrm{C}\left(230^{\circ} \mathrm{F}\right)$ at the end of 2012 . Temperature measurements $270 \mathrm{~cm}(8.9 \mathrm{ft})$ above the RTG and approximately $280 \mathrm{~cm}(9.1 \mathrm{ft})$ below the ground surface are not affected by the heat flux from the RTGs. 


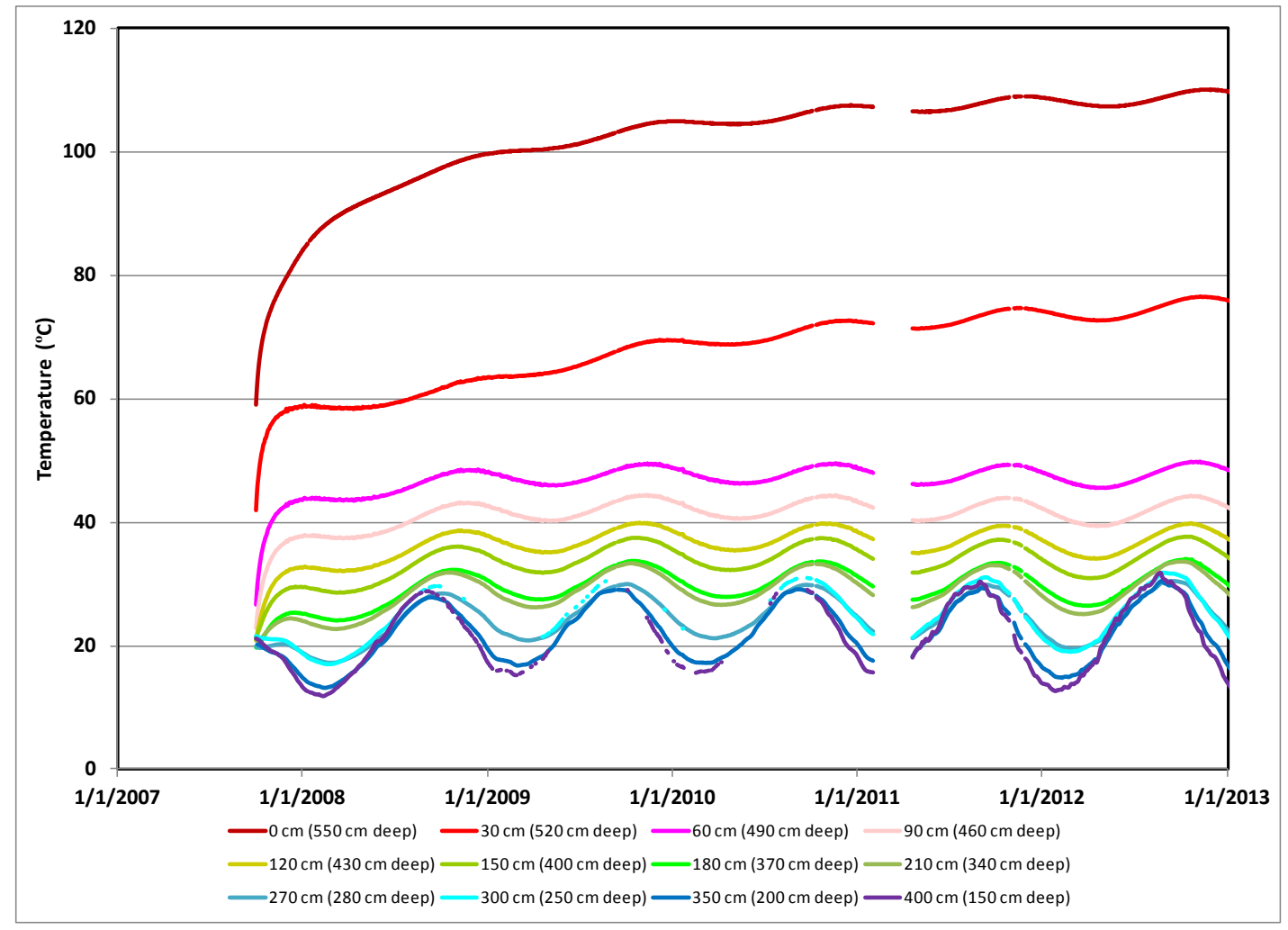

Figure 4-27 Temperatures above an RTG at Pit 5

In December 2000, TDR probes were installed during construction of the final vegetated cover of the U-3ax/bl waste disposal unit at the Area 3 RWMS (Figure 3-1). Eight vertically arranged TDR probes were installed at four locations at depths ranging from 30 to $240 \mathrm{~cm}$ (1 to $8 \mathrm{ft}$ ). Measured soil water content values for one location (East Nest A) in the U-3ax/bl waste cover are shown in Figure 4-28. From 2001 to 2005, the TDR data indicate that the soil water content in the cover generally decreased over time as the vegetation on the cover grew. The precipitation events beginning in October 2004 infiltrated into the final cover of U-3ax/bl, but the moisture has been removed without percolating below the $240 \mathrm{~cm}(8 \mathrm{ft})$ deep sensor. Unlike the bare-soil operational covers on P03, P04, and P05, the moisture at U-3ax/bl was removed by ET before reaching $240 \mathrm{~cm}(8 \mathrm{ft})$. The wetting front from the $6.6 \mathrm{~cm}(2.6 \mathrm{in}$.) precipitation event on September 21 and September 22, 2007, only reached $30 \mathrm{~cm}$ (1 ft) deep as compared to 90 to $120 \mathrm{~cm}$ (3 to $4 \mathrm{ft}$ ) deep in the bare operational covers. Precipitation during January and February 2009 increased water contents to a depth of $30 \mathrm{~cm}(1 \mathrm{ft})$. Precipitation during January

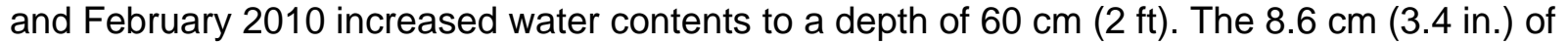
precipitation from December 18 to 23, 2010, increased water contents in the cover to a depth of $122 \mathrm{~cm}(4 \mathrm{ft})$ by May 2011. This moisture did not percolate to $150 \mathrm{~cm}(4.9 \mathrm{ft})$ deep. ET removed this moisture from the cover by October 2011. The $50 \mathrm{~mm}$ (2 in.) of precipitation on October 11, 2012, did not percolate to $60 \mathrm{~cm}(2 \mathrm{ft})$ deep.

Initial water contents are lower in the vegetated U-3ax/bl cover, so more moisture is stored per unit depth as the wetting front moves down. Vegetation is critical to the effectiveness of the 
U-3ax/bl cover. In the native environment, about $12 \%$ of the surface area is covered by plant material. Obtaining $12 \%$ vegetative cover on the soil caps is dependent upon the seed germination success and seedling survival of native plants seeded or transplanted onto the cover. A quantitative analysis of the vegetative cover on the U-3ax/bl cover is conducted annually in the spring. The percent cover for the established U-3ax/bl cover has ranged from $20.2 \%$ in 2005 , to $19.6 \%$ in 2006 , to $10.6 \%$ in 2007 , to $26.8 \%$ in 2008 , to $12.2 \%$ in 2009 , to $19.8 \%$ in 2010 , to $21.2 \%$ in 2011 , and to $13.0 \%$ in 2012 . The dominant perennial plant on the U-3ax/bl cover is Atriplex confertifolia (shadscale saltbush), which accounted for $12.6 \%$ cover.

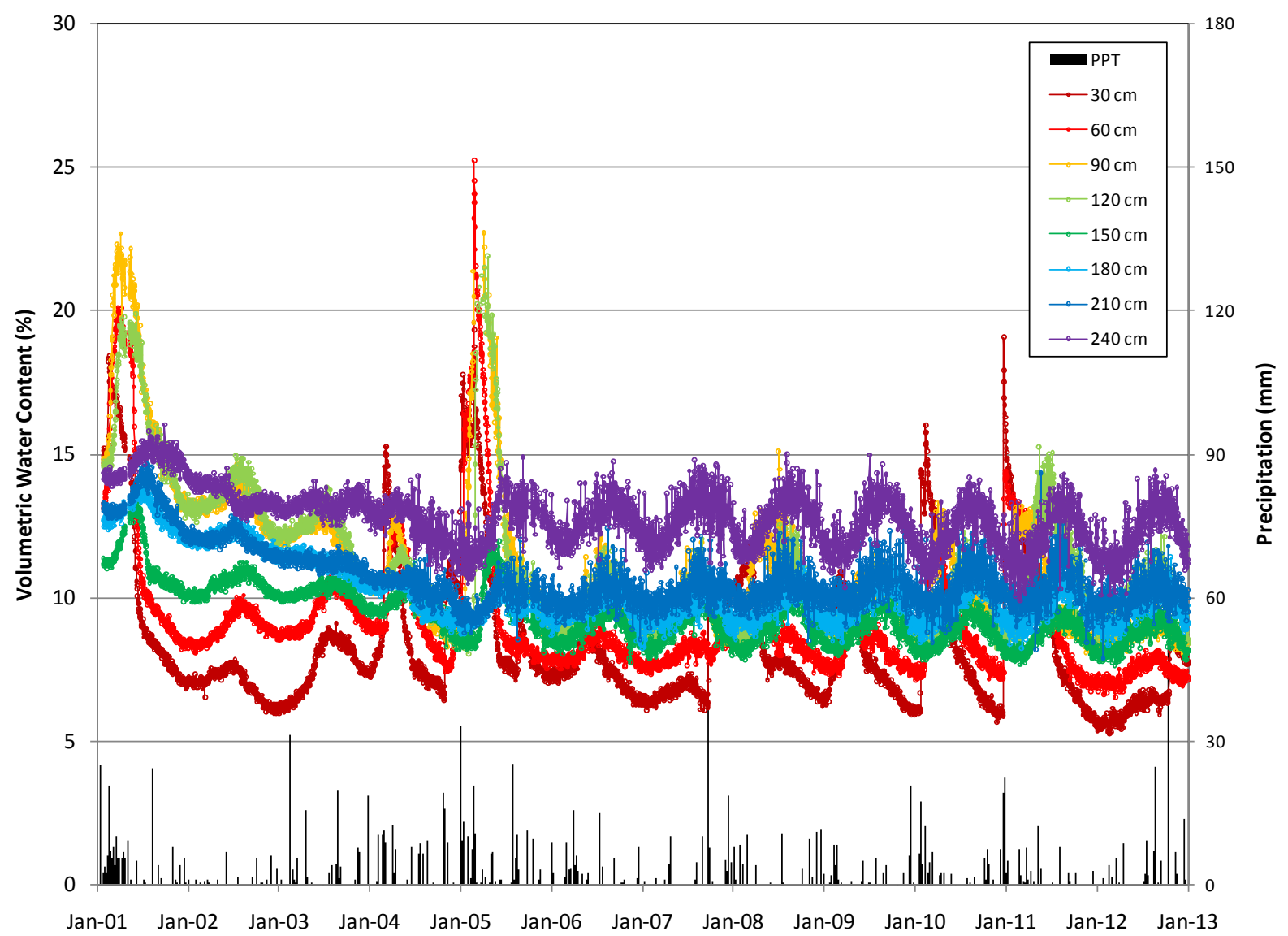

Figure 4-28 Soil Water Content in the U-3ax/bl Cover

\subsubsection{Area 3 Drainage Lysimeter Facility}

The Area 3 Drainage Lysimeter Facility is immediately northwest of the U-3ax/bl waste disposal unit at the Area 3 RWMS (Figure 3-1). This facility is designed to collect saturated gravity drainage from eight lysimeters measuring $3.1 \mathrm{~m}(10 \mathrm{ft})$ in diameter by $2.4 \mathrm{~m}(8 \mathrm{ft})$ deep. The lysimeters are filled with native soil and packed to mimic the U-3ax/bl soil cover. Each lysimeter has eight TDR probes to measure moisture content depth profiles, paired with eight heat dissipation probes to measure soil water potential depth profiles. The probes are installed at $7 \mathrm{~cm}(0.25 \mathrm{ft}), 15 \mathrm{~cm}(0.5 \mathrm{ft}), 30 \mathrm{~cm}(1 \mathrm{ft}), 60 \mathrm{~cm}(2 \mathrm{ft}), 90 \mathrm{~cm}(3 \mathrm{ft}), 120 \mathrm{~cm}(4 \mathrm{ft}), 180 \mathrm{~cm}(6 \mathrm{ft})$, and $240 \mathrm{~cm}(8 \mathrm{ft})$ deep. Measured water content values at the bottom of the lysimeters and drainage from the lysimeters provide an indirect measure of potential drainage from the U-3ax/bl 
soil cover. The lysimeter facility was constructed to fulfill data needed to reduce uncertainty in the expected performance of monolayer-ET closure covers under various surface vegetation treatments and climatic change scenarios such as increased rainfall.

There are three surface vegetation treatments subject to two climate treatments on the lysimeters. The three surface vegetation treatments are bare-soil, invader species (primarily Bromus tectorum [cheatgrass] and Halogeton glomeratus [halogeton]), and native species (primarily Atriplex confertifolia [shadscale saltbush], Krascheninnikovia lanata [winterfat], Ephedra nevadensis [Nevada jointfir], Achnatherum hymenoides [Indian ricegrass], and Elymus elymoides [squirreltail grass]). The climate treatments are natural precipitation and 3-times natural precipitation. The 3-times natural precipitation lysimeters receive natural precipitation and are irrigated with an amount equal to 2-times natural precipitation.

The 2012 lysimeter treatments, precipitation, irrigation, and drainage are summarized in Table 4-5. The eight lysimeters are identified as Lysimeter A through Lysimeter $\mathrm{H}$. Lysimeter $\mathrm{A}$ is bare soil with natural precipitation, Lysimeter $B$ is bare soil with 3-times natural precipitation, Lysimeter $C$ is invader species with natural precipitation, Lysimeter $D$ is invader species with 3-times natural precipitation, Lysimeters $\mathrm{E}$ and $\mathrm{G}$ are native species with natural precipitation, and Lysimeters $\mathrm{F}$ and $\mathrm{H}$ are native species with 3-times natural precipitation.

The 2012 precipitation at the drainage lysimeters was $138 \mathrm{~mm}$ (5.4 in.). The 2012 irrigation applied to Lysimeters B was $254 \mathrm{~mm}$ (10.0 in.), and the 2012 irrigation applied to Lysimeters D, $\mathrm{F}$, and $\mathrm{H}$ was $238 \mathrm{~mm}$ (9.4 in.). On June 27, 2012, $10 \mathrm{~mm}$ (0.4 in.) of irrigation was applied to Lysimeter $E$ and $G$. This irrigation was applied to ensure the native plant species on these lysimeters survived very dry conditions.

There were 577 liters (127 gallons) of drainage from Lysimeter B during 2012. The equivalent depth of this drainage is $7.9 \mathrm{~cm}$ (3.1 in.). Drainage from Lysimeter B occurred from September 5, 2012 , to December 31,2012 . The Lysimeter B drainage is $20 \%$ of total precipitation and applied irrigation. There was no drainage from any other lysimeter during 2012. Drainage has only occurred from the irrigated lysimeters. Total cumulative drainage from each irrigated lysimeter is $149.6 \mathrm{~cm}$ (58.9 in.) from Lysimeter B, $6.5 \mathrm{~cm}$ (2.6 in.) from Lysimeter D, $29.6 \mathrm{~cm}$ (11.7 in.) from Lysimeter F, and $12.3 \mathrm{~cm}$ (4.8 in.) from Lysimeter H (Figure 4-29).

Cover was measured for each of the eight drainage lysimeters on May 23, 2012. The results are summarized in Table 4-6. 
Table 4-5 Area 3 Drainage Lysimeter Treatments in 2012

\begin{tabular}{||clcccl||}
\hline \hline Lysimeter & \multicolumn{1}{c}{ Climate } & $\begin{array}{c}\text { Precipitation } \\
(\mathrm{mm})\end{array}$ & $\begin{array}{c}\text { Irrigation } \\
(\mathrm{mm})\end{array}$ & $\begin{array}{c}\text { Drainage } \\
(\mathrm{mm})\end{array}$ & Surface Vegetation \\
\hline A & Natural precipitation & 138 & 0 & 0 & Bare-soil \\
B & 3-times natural precipitation & 138 & 254 & 79 & Bare-soil \\
C & Natural precipitation & 138 & 0 & 0 & Invader species \\
D & 3-times natural precipitation & 138 & 238 & 0 & Invader species \\
E & Natural precipitation & 138 & 10 & 0 & Native species \\
F & 3-times natural precipitation & 138 & 238 & 0 & Native species \\
G & Natural precipitation & 138 & 10 & 0 & Native species \\
H & 3-times natural precipitation & 138 & 238 & 0 & Native species \\
\hline
\end{tabular}

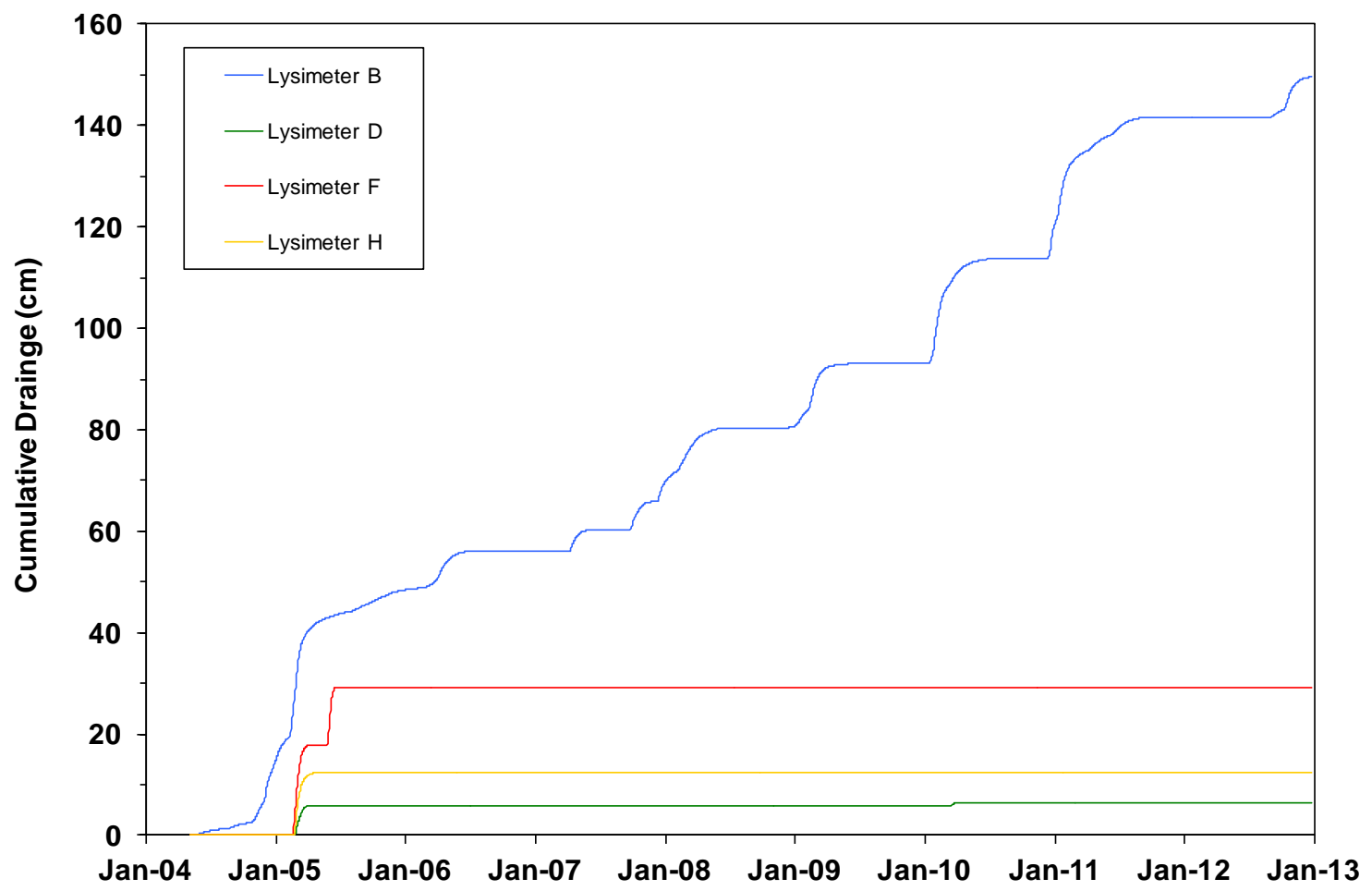

Figure 4-29 Cumulative Drainage from the Drainage Lysimeters 
Table 4-6 Area 3 Drainage Lysimeter Percent Cover

\begin{tabular}{||ccccc|}
\hline Lysimeter & $\begin{array}{c}\text { Plant Cover } \\
\text { (percent) }\end{array}$ & $\begin{array}{c}\text { Bare } \\
\text { (percent) }\end{array}$ & $\begin{array}{c}\text { Gravel } \\
\text { (percent) }\end{array}$ & $\begin{array}{c}\text { Litter } \\
\text { (percent) }\end{array}$ \\
\hline A & 0.0 & 32.50 & 67.5 & 0.0 \\
B & 0.0 & 15.0 & 67.5 & 17.5 \\
C & 2.5 & 30.5 & 10.0 & 57.5 \\
D & 0.0 & 2.5 & 97.5 & 0.0 \\
E & 5.0 & 2.5 & 0.0 & 92.5 \\
F & 37.5 & 0.0 & 0.0 & 62.5 \\
G & 2.5 & 12.5 & 0.0 & 85.5 \\
H & 22.50 & 0.0 & 0.0 & 77.5 \\
\hline
\end{tabular}

Figure 4-30 shows the total water storage for all eight lysimeters from 2004 through 2012. Water storage is calculated using TDR data. The two bare-soil lysimeters (Lysimeters A and B) had the highest water storage. Evaporation and drainage are the only processes that remove water from these two lysimeters. The water storage in Lysimeter D was also high at the end of 2012. Heavy rainfall and irrigation during the fall of 2012 was not removed by ET by the invader species on Lysimeter $\mathrm{D}$. The annual invader species were dying when the precipitation and irrigation occurred. Water storage in the other irrigated lysimeters (Lysimeters $D, F$, and $H$ ) was elevated at the beginning of 2011. ET removed most of this water in the spring and summer.

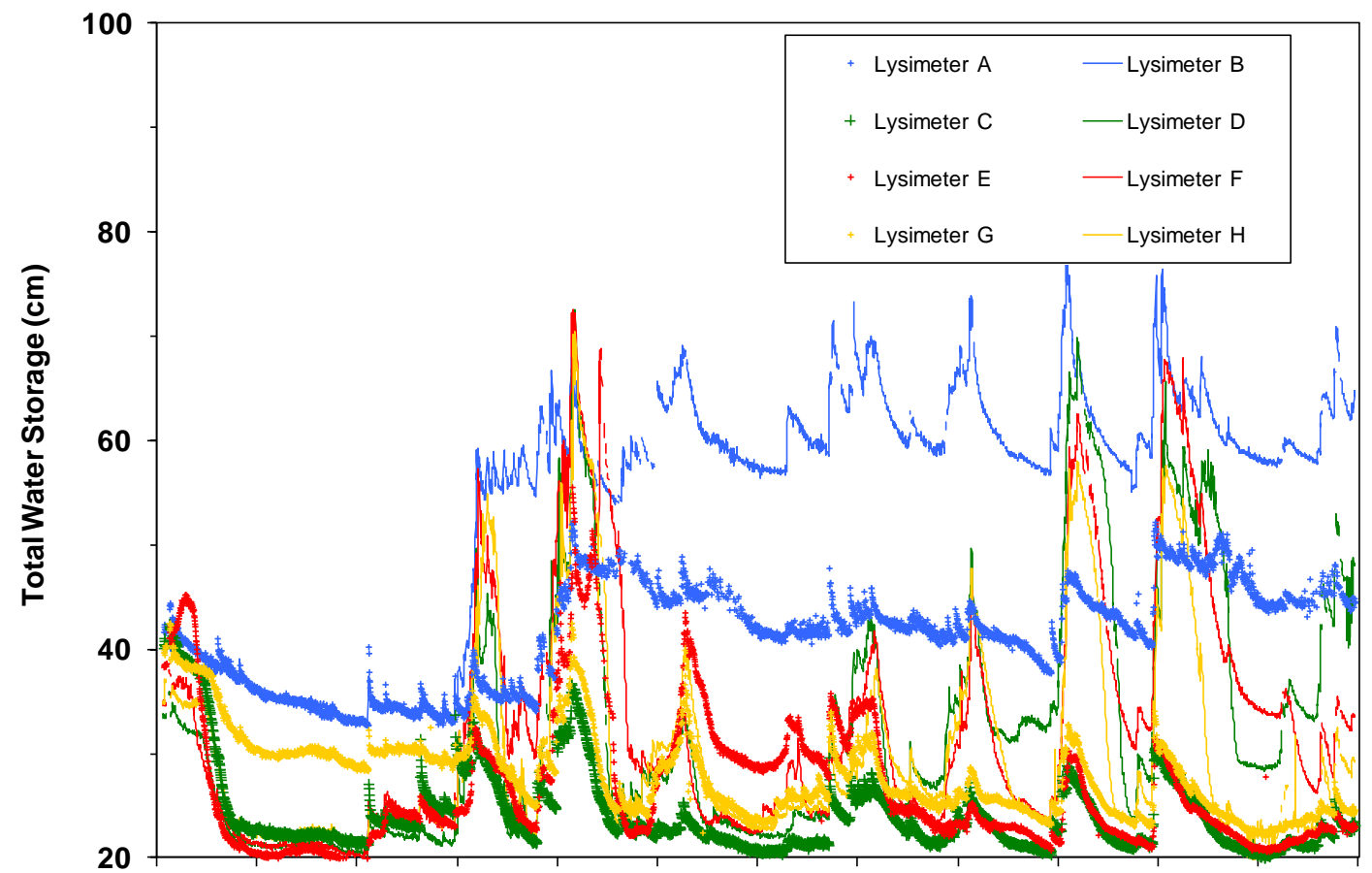

Jan-01 Jan-02 Jan-03 Jan-04 Jan-05 Jan-06 Jan-07 Jan-08 Jan-09 Jan-10 Jan-11 Jan-12 Jan-13

Figure 4-30 Soil Water Storage in the Drainage Lysimeters 


\subsection{WASTE COVER SUBSIDENCE}

Subsidence monitoring is conducted to ensure that subsidence features are repaired to prevent the development of preferential water migration pathways through the waste covers and also helps ensure that vadose zone monitoring data are representative of the entire RWMS. Typically as small depressions or cracks are observed in operational covers, they are filled before large subsidence features develop.

Quarterly inspections of the U-3ax/bl final ET cover look for evidence of cracks, settling, erosion, and subsidence. Inspections were done on March 13, June 19, September 13, and December 10, 2012. As a result of these inspections, two subsidence areas were observed and repaired during 2012. Seven subsidence markers were installed in U-3ax/bl cover, and an initial elevation survey of these markers was completed in December 2000. Subsidence surveys were done approximately twice a year through March 2012. Subsidence measurements at each marker on March 22, 2012, were 1.5, 1.8, 1.2, 1.8, 4.0, 1.8, and $1.8 \mathrm{~cm}(0.05,0.06,0.04,0.06,0.13,0.06$, and $0.06 \mathrm{ft})$. The subsidence survey interval was increased to 2 years after the March 2012 survey (NNSA/NSO, 2013).

Quarterly inspections of the 92-Acre Area final ET cover look for evidence of cracks, settling, erosion, and subsidence. This cover is also inspected when more than $2.5 \mathrm{~cm}$ (1.0 in.) of precipitation occurs in a day. Quarterly inspections were done on March 29, June 27, September 13, and December 18, 2012, and inspections after rainfall were done on August 23 and October 15, 2012. As a result of these inspections, erosion rills on the cover side slope, a crack, and four subsidence areas were repaired during 2012 (NNSA/NSO, 2013). Fifty-two subsidence markers were installed in the 92-Acre Area cover, and an initial elevation survey of these markers was completed in January 2012. Subsidence was measured at each marker on November 21 and 22, 2012. The average subsidence at the 52 subsidence markers was $0.02 \mathrm{ft}$ $(0.6 \mathrm{~cm})$ and the median subsidence was $0.03 \mathrm{ft}(0.9 \mathrm{~cm})$.

\subsection{BIOTA MONITORING DATA}

No radiological biota monitoring data was collected during 2012.

The U-3ax/bl cover was planted with native vegetation during December 2000. Surveys of plant cover and plant density have been conducted annually since 2001 . Results from the May 23, 2012, plant cover survey showed $13 \%$ plant cover, $59 \%$ bare soil or rock, and $28 \%$ plant litter. The primary plant species observed in 2012 was Atriplex confertifolia (shadscale saltbush), which accounted for $12.6 \%$ cover. Figure $4-31$ provides the plant cover data for the U-3ax/bl cover. Perennial plant cover and density have maintained at steady levels over the last 5 years. Low 2012 precipitation resulted in the decline in overall plant cover. The decrease was due to the complete absence of annual forbs. There were no invasive weedy species present on the site in 2012. 


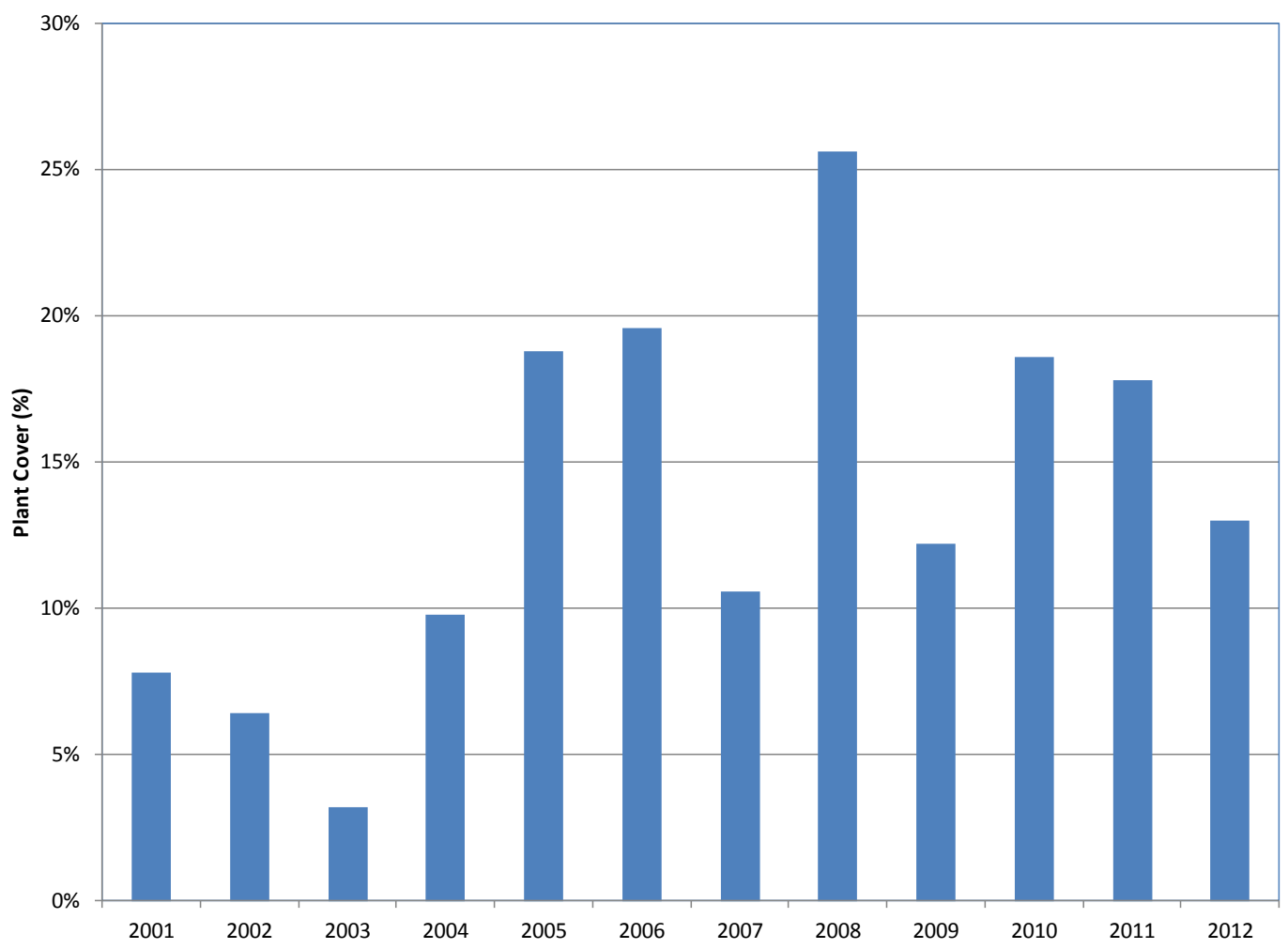

Figure 4-31 Percent Plant Cover on the U-3ax/bl Cover 
THIS PAGE INTENTIONALLY LEFT BLANK 


\subsection{CONCLUSION}

The 2012 environmental and operational monitoring data from the Area 3 and Area 5 RWMSs indicate that these facilities are performing as expected for the long-term isolation of buried waste. Direct radiation exposure data indicate a rate that is well below any dose of concern, and air monitoring data indicate that concentrations of radioactive materials in air remain below any concentrations of concern. Groundwater and vadose zone monitoring data indicate that the groundwater beneath the Area 5 RWMS is unaffected by the waste disposal operations. Vadose zone monitoring data indicate that vegetation prevents infiltrating precipitation from percolating deep into the soil by returning the moisture to the atmosphere by ET. Long-term vadose zone monitoring data from the weighing lysimeters indicate no drainage through the bottoms of the vegetated lysimeters. All 2012 monitoring data indicate that the Area 3 and Area 5 RWMSs are performing within expectations of the model and parameter assumptions for the facility PAs. 
THIS PAGE INTENTIONALLY LEFT BLANK 


\subsection{REFERENCES}

Air Resources Laboratory, Special Operations and Research Division, 2013. NOAA Air Resources Laboratory. http://www.sord.nv.doe.gov. [Accessed August 9, 2013].

Allen, R. G., I. A. Walter, R. L. Elliot, T. A. Howell, D. Itenfisu, M. E. Jensen, and R. L. Snyder, 2005. The ASCE Standardized Reference Evapotranspiration Equation. American Society of Civil Engineers.

ARL/SORD, see Air Resources Laboratory, Special Operations and Research Division.

Bechtel Nevada, 1998. Hydrogeologic Characterization of the Unsaturated Zone at the Area 3 Radioactive Waste Management Site. Volume 1: "Data Interpretations." Volume 2: "Data." DOE/NV/11718--210. February 1998.

Bechtel Nevada, 2001. Closure Report for Corrective Action Unit 110: Area 3 RWMS U-3ax/bl Disposal Unit, Nevada Test Site, Nevada. DOE/NV/11718--743. June 2001.

Bechtel Nevada, 2003. Nevada Test Site Routine Radiological Environmental Monitoring Plan. DOE/NV/11718--804. Bechtel Nevada. June 2003.

Bechtel Nevada, 2005a. Site Characterization and Monitoring Data from Area 5 Pilot Wells. DOE/NV/11718--1067. September 2005.

Bechtel Nevada, 2005b. Site Characterization Data from the U-3ax/bl Exploratory Boreholes. DOE/NV/11718--003-Rev1. August 2005.

Bechtel Nevada, 2006. Characterization Report for the 92-Acre Area of the Area 5 Radioactive Waste Management Site, Nevada Test Site, Nevada. DOE/NV/11718--1154. June 2006.

Blout, D. O., D. P. Hammermeister, K. A. Zukosky, and K. D. Donnelson, 1995. Site Characterization Data from Area 5 Science Boreholes, Nevada Test Site, Nye County, Nevada. DOE/NV/11432--170. Reynolds Electrical \& Engineering Co., Inc. February 1995.

BN, see Bechtel Nevada.

Campbell, G. S., 1977. An Introduction to Environmental Biophysics. Heidelberg Science Library. Springer-Verlag, New York.

Cochran, J. R., W. E. Beyeler, D. A. Brosseau, L. H. Brush, T. J. Brown, B. Crowe, S. H. Conrad, P. A. Davis, T. Ehrhorn, T. Feeney, B. Fogleman, D. P. Gallegos, R. Haaker, D. Kalinina, L. L. Price, D. P. Thomas, and S. Wirth, 2001. Compliance Assessment Document for the Transuranic Wastes in the Greater Confinement Disposal Boreholes at the Nevada Test Site. Sandia Report SAND2001-2977. Sandia National Laboratories. September 2001.

Desotell, L. T., D. B. Hudson, V. Yucel, and J. T. Carilli, 2006. "Use of Long-Term Lysimeter Data in Support of Shallow Land Waste Disposal Cover Design." In: Proceedings of the Waste Management '06 Conference. February 26-March 2, 2006. Tucson, Arizona. 
Desotell, L. T., D. B. Hudson, D. Anderson, V. Yucel, G. Shott, G. L. Pyles, and J. T. Carilli, 2007. "Performance of Evapotranspirative Covers under Enhanced Precipitation: Preliminary Data." In: Proceedings of the Waste Management '07 Conference. February 26-March 1, 2007. Tucson, Arizona.

Doorenbos, J., and W. O. Pruitt, 1977. Guidelines for Predicting Crop Water Requirements. FAO Irrigation and Drainage Paper No. 24, 2d ed. U.N. Food and Agricultural Organization. Rome, Italy.

Goodrich, J. G., 2010. Design of Revisions to the Evapotranspiration Cover for the 92-Acre Area: Area 5 Waste Management Division Retired Mixed Waste Pits Nevada National Security Site, Nevada. October 2010.

Levitt, D. G., and V. Yucel, 2002. "Potential Groundwater Recharge and the Effects of Soil Heterogeneity on Flow at Two Radioactive Waste Management Sites at the Nevada Test Site." In: Proceedings of the 2002 International Groundwater Symposium. March 25-28, 2002. Berkeley, California.

Levitt, D. G., M. J. Sully, B. L. Dozier, and C. F. Lohrstorfer, 1999. "Determining the Performance of an Arid Zone Radioactive Waste Site through Site Characterization, Modeling, and Monitoring." In: Proceedings of the Waste Management '99 Conference. February 28-March 4, 1999. Tucson, Arizona.

National Security Technologies, LLC, 2007a. Characterization Report Area 3 Radioactive Waste Management Site Nevada Test Site, Nevada. DOE/NV/25946--080. March 2007.

National Security Technologies, LLC, 2007b. Closure Plan for the Area 3 Radioactive Waste Management Site at the Nevada Test Site. DOE/NV/25946--289. September 2007.

National Security Technologies, LLC, 2008. Closure Plan for the Area 5 Radioactive Waste Management Site at the Nevada Test Site. DOE/NV/25946--553. September 2008.

National Security Technologies, LLC, 2012. Nevada Test Site Environmental Report 2011. DOE/NV/25946--1604. September 2012.

National Security Technologies, LLC, 2013a. Nevada National Security Site 2012 Data Report: Groundwater Monitoring Program, Area 5 Radioactive Waste Management Site. DOE/NV/25946--1683. February 2013.

National Security Technologies, LLC, 2013b. National Emission Standards for Hazardous Air Pollutants - Radionuclide Emissions, Calendar Year 2012. DOE/NV/25946--1796. June 2013.

NNSA/NSO, see U.S. Department of Energy, National Nuclear Security Administration Nevada Site Office.

NSTec, see National Security Technologies, LLC.

Plannerer, H. N., 1996. Siting Criteria for Angle Drilling Under the U-3ah/at Disposal Unit. Los Alamos National Laboratory Report LA-UR-96-1679. May 13, 1996. 
Reynolds Electrical \& Engineering Co., Inc., 1993a. Hydrogeologic Data for Existing Excavations at the Area 5 RWMS, Nevada Test Site, Nye County, Nevada. DOE/NV/11432--40. December 1993.

Reynolds Electrical \& Engineering Co., Inc., 1993b. Hydrogeologic Data for Science Trench Boreholes at the Area 5 RWMS, Nevada Test Site, Nye County, Nevada. December 1993.

Shott, G. J., V. Yucel, M. J. Sully, L. E. Barker, S. E. Rawlinson, and B. A. Moore, 1997. Performance Assessment/Composite Analysis for the Area 3 Radioactive Waste Management Site at the Nevada Test Site, Nye County, Nevada. Revision 2.1. DOE/NV--491-REV 2.1. Bechtel Nevada. September 1997.

Shott, G. J., L. E. Barker, S. E. Rawlinson, M. J. Sully, and B. A. Moore, 1998. Performance Assessment for the Area 5 Radioactive Waste Management Site at the Nevada Test Site, Nye County, Nevada. Revision 2.1. DOE/NV/11718--176. Bechtel Nevada. January 1998.

Soule, D. A., 2006. Climatology of the Nevada Test Site. Air Resources Laboratory, Special Operations and Research Division 2006-03. April 2006.

Snyder, K. E., R. D. Van Remortel, D. L. Gustafson, H. E. Huckins-Gang, J. J. Miller, S. E. Rawlinson, and S. M. Parsons, 1995. Surficial Geology and Landscape Development in Northern Frenchman Flat, Interim Summary and Soil Data Report. DOE/NV/25946--466. Raytheon Services Nevada. September 1995.

The Delphi Groupe and J. A. Cesare and Associates, 2012. Evapotranspiration Cover for the 92-Acre Area Retired Mixed Waste Pits, Area 5 Waste Management Division, Nevada National Security Site, Final CQA Report. DOE/NV/25946--1428, January 2012.

Tyler, S. W., J. B. Chapman, S. H. Conrad, D. P. Hammermeister, D. O. Blout, J. J. Miller, M. J. Sully, and J. M. Ginanni, 1996. "Soil-Water Flux in the Southern Great Basin, United States: Temporal and Spatial Variations over the Last 120,000 Years." Water Resources Research. Vol. 32, No. 6, pp. 1481-1499.

U.S. Department of Energy, Nevada Operations Office, 2000. Closure Plan for Corrective Action Unit 110: Area 3 RWMS U-3ax/bl Disposal Site, Nevada Test Site, Nevada. DOE/NV--647. August 2000.

U.S. Department of Energy, Nevada Operations Office, 2001. Closure Report for Corrective Action Unit 110: Area 3 RWMS U-3ax/bl Disposal Unit, Nevada Test Site, Nevada. DOE/NV--733-REV1. August 2001.

U.S. Department of Energy, National Nuclear Security Administration Nevada Site Office, 2010. Corrective Action Decision Document/Corrective Action Plan for the 92-Acre Area and Corrective Action Unit 111: Area 5 WMD Retired Mixed Waste Pits, Nevada National Security Site, Nevada. DOE/NV--1326-REV1. November 2010.

U.S. Department of Energy, National Nuclear Security Administration Nevada Site Office, 2012. Closure Report for the 92-Acre Area and Corrective Action Unit 111: Area 5 WMD Retired Mixed Waste Pits, Nevada National Security Site, Nevada. DOE/NV--1472. February 2012. 
U.S. Department of Energy, National Nuclear Security Administration Nevada Site Office, 2013. Post Closure Report for the Closed Resource Conservation and Recovery Act Corrective Action Units, Nevada National Security Site, Nevada. DOE/NV--1493. January 2013. 


\section{DISTRIBUTION LIST}

$\underline{\text { U.S. Department of Energy }}$

Jhon T. Carilli

LLW Federal Sub-Project Director, Waste Management Project

U.S. Department of Energy

National Nuclear Security Administration

Nevada Field Office

P.O. Box $98518 \mathrm{M} / \mathrm{S} 505$

Las Vegas, NV 89193-8518

Kenneth M. Small

RCRA Program Manager, Waste Management Project

U.S. Department of Energy

National Nuclear Security Administration

Nevada Field Office

P.O. Box 98518 M/S 505

Las Vegas, NV 89193-8518

U.S. Department of Energy

National Nuclear Security Administration

Nevada Field Office

Public Reading Facility

c/o Nuclear Testing Archive

P.O. Box 98521, M/S 400

Las Vegas, NV 89193-8521

U.S. Department of Energy

Office of Scientific and Technical Information

P.O. Box 62

Oak Ridge, TN 37831-0062
Copies

4

1

2 (CD)

1 digital file 
National Security Technologies, LLC

David B. Hudson

National Security Technologies, LLC

P.O. Box 98521, M/S NLV083

Las Vegas, NV 89193-8521

Theodore J. Redding

National Security Technologies, LLC

P.O. Box 98521, M/S NNSS273

Las Vegas, NV 89193-8521

Gregory J. Shott

National Security Technologies, LLC

P.O. Box 98521, M/S NLV083

Las Vegas, NV 89193-8521

Ronald W. Warren

1

National Security Technologies, LLC

P.O. Box 98521, M/S NNSS273

Las Vegas, NV 89193-8521

Vefa Yucel

1

National Security Technologies, LLC

P.O. Box 98521, M/S NLV083

Las Vegas, NV 89193-8521 